University of Rhode Island

DigitalCommons@URI

Open Access Master's Theses

1981

\title{
QUONSET-DAVISVILLE REDEVELOPMENT: AN ANALYSIS OF THE IMPACTS ON AN AREA OF NORTH KINGSTOWN, RHODE ISLAND
}

Joseph S. Mannarino

University of Rhode Island

Follow this and additional works at: https://digitalcommons.uri.edu/theses

\section{Recommended Citation}

Mannarino, Joseph S., "QUONSET-DAVISVILLE REDEVELOPMENT: AN ANALYSIS OF THE IMPACTS ON AN AREA OF NORTH KINGSTOWN, RHODE ISLAND" (1981). Open Access Master's Theses. Paper 488.

https://digitalcommons.uri.edu/theses/488

This Thesis is brought to you for free and open access by DigitalCommons@URI. It has been accepted for inclusion in Open Access Master's Theses by an authorized administrator of DigitalCommons@URI. For more information, please contact digitalcommons-group@uri.edu. 
QUONSET - DAVISVILLE REDEVELOPMENT:

AN ANALYSIS OF THE IMPACTS

ON AN AREA OF NORTH KINGSTOWN, RHODE ISLAND

BY

JOSEPH S. MANNARINO

A RESEARCH PROJECT SUBMITTED IN

PARTIAL FULFILLMENT OF THE REQUIREMENTS

FOR THE DEGREE OF MASTER OF

COMMUNITY PLANNING

UNIVERS ITY OF RHODE ISLAND

1981 


\section{MASTER OF COMMUNITY PLANNING}

\section{RESEARCH PROJECT}

OF

JOSEPH S. MANNARINO

APPROVED:

MAJOR PROFESSOR

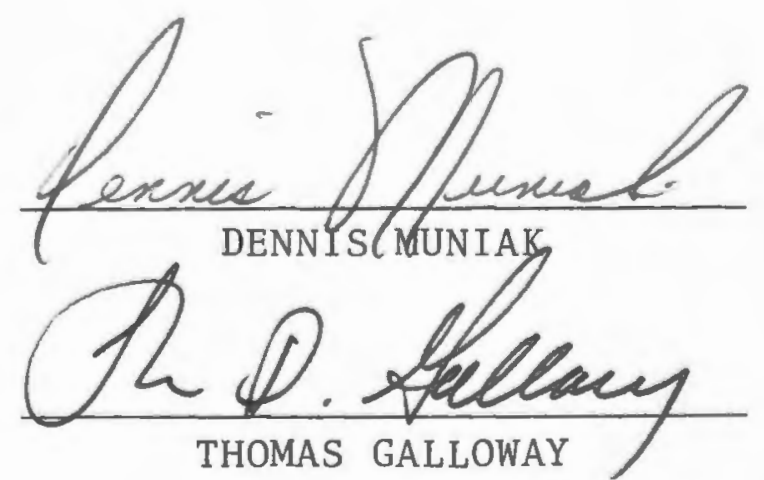





\section{ACKNOWLEDGMENTS}

I would Iike to thank Professor Dennis Muniak for his guidance and interest in this study. In addition, special thanks should be given to Jack Lenox and Cheryl Friend for their timely comments and advise. My appreciation also extends to John Hughes for his positive suggestions. I would also like to thank Anne Marie Cournoyer for typing this report. And lastly, I am grateful to my wife Dorothy for her constant support and assistance. 


\section{PREFACE}

The purpose of this report is to provide the Town of North Kingstown with an analysis of the impacts of QuonsetDavisville redevelopment. The target for this analysis is the area directly adjacent to the site, which comprises Census Tract 501.01 to the north and Census Tract 501.02 to the south. In particular, this study will concentrate on the employment-related aspects of the redevelopment proposals. Hence, the financial and capital investment projections of the various development scenarios will only be briefly touched upon .

This report includes the following:

Introduction contains a summarized historical description of the major turning points for Quonset-Davisville and the Town of North Kingstown. This section also discusses the significant changes that have occurred in the target area adjacent to the site (Census Tract 501.01 and Census Tract $501.02)$.

\section{Chapter I/Quonset-Davisville: A Potential Industrial}

Complex 1 ists and maps the four major 1 and owners at the site. Also included is an overview of the three Quonset-Davisville Scenarios designed by the Rhode Island Economic Development Corporation. An inventory of the site facilities and cost estimates for site improvements are also discussed. In 
addition, a detailed analysis of the projected employment is examined.

Chapter II/Profile and Analysis of the Target Area includes an outline for population growth, public facilities, and current 1and uses for Census Tract 501.01 and Census Tract 501.02. The second part of this chapter analyses the future 1 and development pressure due to the employment projections of Quonset-Davisville. The land in each Census Tract is examined for its development potential. Chapter III/Impacts on Municipal Employment and Budget summarizes the important aspects of the agreement between the Town of North Kingstown and the State of Rhode Island. Also, the methodology used to determine the number of future municipal employees needed in North Kingstown due to QuonsetDavisville growth will be outlined. Chapter III then goes on to explain the employment projections for each of the municipal functions. In addition, the municipal costs and revenues associated with three particular types of residential development mixes will be examined. 


\section{TABLE OF CONTENTS}

ACKNOWLEDGMENTS

PREFACE

INTRODUCTION

Chapter

I. QUONSET-DAVISVILLE: A POTENTIAL INDUSTRIAL COMPLEX

A. Quonset-Davisville Property Ownership

B. Development Scenarios

C. Site Facilities and Improvements

D. Projected Employment

II. PROFILE AND ANALYSIS OF TARGET AREA

A. Profile of Census Tract 501.01

1. Population Growth

2. Land Use

3. Public Facilities

B. Future Land Development Pressure $(501.01)$

1. Methodology

2. Constraints to Development

3. Growth Projections

C. Profile of Census Tract 501.02

1. Population Growth

2. Public Facilities 46

3. Land Use 
D. Future Development Pressure

$(501.02) \quad 52$

1. Constraints to Development 52

2. Growth Projections 53

III. IMPACTS ON MUNICIPAL EMPLOYMENT AND BUDGET 58

A. The Agreement 58

B. Impact Evaluation Methodology 61

C. Additional Households and Residents 61

D. Future Pubiic Service Employment $\begin{array}{ll}\text { Needs } & 67\end{array}$

E. Impacts on Target Area Schools 70

F. Municipal Cost and Revenues of

Residential Development $\quad 78$

$\begin{array}{lr}\text { CONCLUSION } & 83\end{array}$

$\begin{array}{lr}\text { FOOTNOTES } & 88\end{array}$

APPENDIX

A. CIVILIAN POPULATION OF NORTH KINGSTOWN

B. PROJECTED OCCUPATIONAL MIX 94

C. DESCRIPTION OF DEVELOPMENT CONSTRAINTS 98

D. RESIDENTIAL ZONING CATEGORIES 106

E. PROJECTED RESIDENTS AND SCHOOL CHILDREN

$\begin{array}{lll}\text { (CENSUS TRACT 501.01 AND 501.02) } & 111\end{array}$

$\begin{array}{ll}\text { B I BL I OGRAPHY } & 114\end{array}$ 
Table

16. 1980 Land Use Data, Tract 501.02

17. Developable Land in Census Tract 501.02

18. Developable Land in Zoning Category

Tract 501.02

19. Number of Possible House Lots Under

Current Zoning Restrictions Census

Tract 501.02

20. Number of Employees Expected to Reside

in North Kingstown Year 25

21. Number of New Housing Units and Additional

Residents Expected in North Kingstown

AHA Result of O/D Development

22. Current and Projected Employment for

Three Development Alternatives

23. Projected School System Man-Power

Increases

24. Inventory of School Facilities

25. Distribution of School Age Children

26. Municipal Costs of Residential

Development

27. Costs of Quonset-Davisville Related

Development Tract 501.01

28. Costs of Quonset-Davisville Related

Development Tract 501.02

29. 1980 Preliminary Census Data

30. Occupational Mix Projected QuonsetDavisville Uses in 25 Years, Scenario I 
Table

31. Occupational Mix Projected Quonset-

Davisville Uses in 25 Years, Scenario II

32. Occupational Mix Projected Quonset-

Davisville Uses in 25 Years, Scenario III

33. Quonset-Davisville Related Residents and

School Age Children, Census Tract 501.01

34. Quonset-Davisville Related Residents and

School Age Children, Census Tract 501.02

113 


\section{LIST OF MAPS}

1. Map of North Kingstown, High1ight QuonsetDavisville

2. Map of North Kingstown, High1ight Census Tracts 501.01 and 501.02

3. Property Ownership: Quonset-Davisville

4. Quonset-Davisvil1e, Development Scenario I

5. Quonset-Davisville, Development Scenario II

6. Quonset-Davisvi11e, Development Scenario III

7. Quonset-Davisville Facilities Map

8. Public Facilities in Census Tract 501.01

9. Proposed and Potential Development Areas Tract 501.01

10. Recommended Census Tract 501.02 Boundary Changes

11. Public Facilities in Census Tract 501.02

12. Proposed and Potential Development Areas

Tract 501.02

13. Schoo1 Locations Tracts 501.01 and 501.02 


\section{INTRODUCTION}

Preparation is now underway at the Quonset-Davisville site for the largest industrial-technical park in Rhode Island. This site, located in the northern portion of North Kingstown, contains approximate 1 y 3,000 acres, 850 of which were purchased by the state in 1979 for $\$ 8.8$ million (see map 1). Together with the 323 acres received in earlier transactions, the state intends to broaden its economic base and maximize the regional employment at this location. 1

The most significant events leading up to the present status of Quonset-Davisville began shortly before World War I. In the early 1900s, the site was used predominantly by summer residents and by the Rhode Island Militia Brigade. The number of residents in North Kingstown at that time was only about 4,194. By 1920, the town lost some of its population as the total number of residents dropped to 3,397 . This decrease began reversing in the $1930 s$ as the population grew to 4,604 by $1940 . .^{2}$

The major factor influencing growth was the Rhode Island Militia Brigade Camp being donated to the federal government for the purpose of establishing a National Naval Training Center. One important stipulation in this transaction was that the donated property would have to revert to the state when it was no longer needed as a military installation. 3 In June of 


\section{NORTH KINGSTOWN}

84 Quonset-Davisville
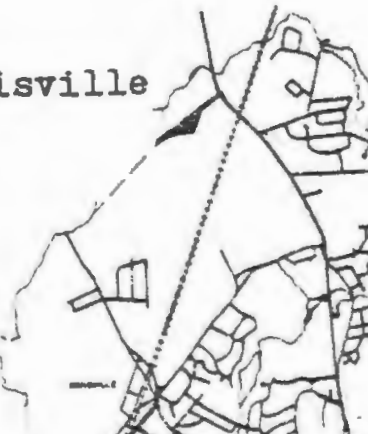
1940, the United States Congress passed an appropriations bill for the actual construction of the Naval Air Station at Quonset. With a construction task force of more than 11,000 men, working round the clock seven days a week, the station and training center were completed within one year. ${ }^{4}$

The rapid expansion of Quonset-Davisville resulted in dramatic changes in North Kingstown's appearance. The growth from approximately 10,000 new residents by 1950 began transforming a relatively quiet agricultural area to a busy and vital suburban community. This change was most evident in the areas directly adjacent to the site Census Tract 501.01 to the north and Census Tract 501.02 to the south (see map 2).

The gently rolling hills of Tract 501.01 which were excellent for agriculture were also good for residential and commercial uses. This rapid development of Quonset-Davisville especially affected the manner in which homes were laid out in a subdivision. Large subdivisions such as Yorktown Manor, Sand Hill Terrace, and Quonset Manor were all financed by the Federal Housing Administration to make housing available for nonmilitary Quonset workers. ${ }^{5}$ These designs were considered progressive because they included curved street patterns, provisions for parks, and separation of interior residential streets from heavily traveled arterial roads such as post Road.

As the homes began springing up over the landscape, so followed the businesses. In fact, the most starting change occurred along Post Road. This north-south arterial soon became bordered by one hundred stores in an area served in the late 
MAP 2

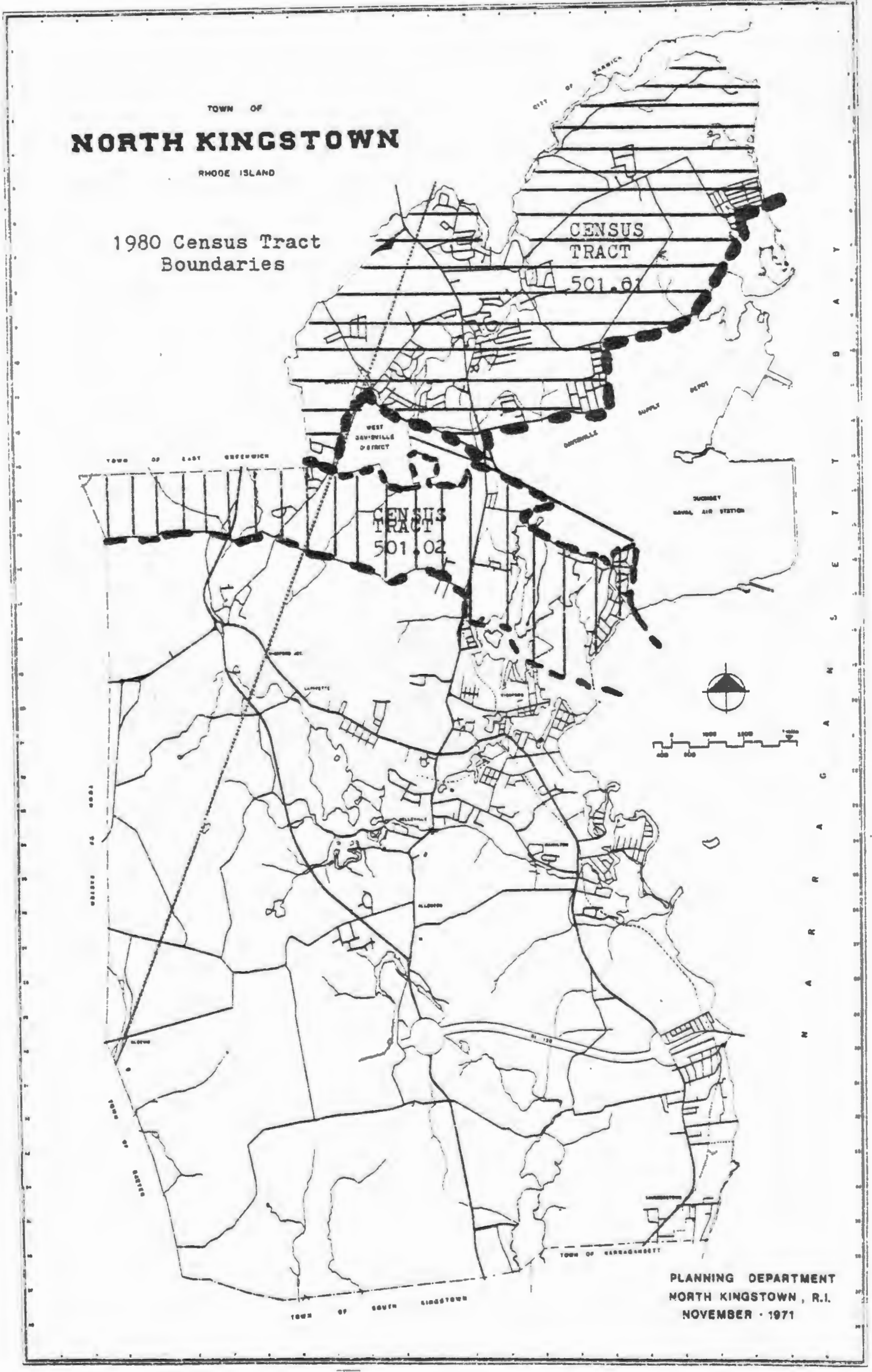


1800 s by only one general store. ${ }^{6}$ since the area never had a village core, uncontrolled growth began to take place. Today shopping centers, restaurants, gasoline stations, and a wide variety of other activities form an almost unbroken chain of development along Post Road.

The area bordering the southern boundary of QuonsetDavisville has, 1ike Tract 501.01 , been transformed over the years from agricultural uses to more intense activities. There are currently densely populated subdivisions, sprawled commercial activities, and a general proliferation of the automobile in this part of town. However, important differences exist between the two districts. First, on $1 y$ the eastern portion of Tract 501.02 underwent this transformation. This area contains multi-family subdivisions such as Hoskins Park, Military Drive, Navy I and Navy II that were constructed to house the thousands of military personnel and their families. Conversely, the area west of Post Road still remains relatively sparsely populated. Large lot single-family homes and large agricultural parcels reflect the fact that this portion of the tract has escaped much of the growth pressure.

Even after the war had ended in 1945 , the activities at Quonset remained essentially the same: providing an operational base for aircraft and ships. Davisville, which was inactive after World War II, was reestablished at the time of the Korean War in the early 1950s. This site specialized in developing and testing equipment for the Navy's Antarctic activities and also contained the Air Rework Facility, a manufacturing and 
service operation. ${ }^{7}$ By 1970 , the continuation of the base development and the phenomenon of suburbanization caused the local population to swell to almost $30,000 .^{8}$

In April 1973, an announcement was made by the Department of the Navy which had dramatic consequences for the Town of North Kingstown. The Navy decided to withdraw most of its activities from Quonset-Davisville by 1974. In effect, the accumulation of 33 years of military growth and dependence was eliminated in one short year. For local businessmen and town officials alike this situation created severe economic problems.

In fact, the town suffered a loss of approximately 11,000 military personnel and their families (see appendix A). Estimates also indicate that some 6,000 civilian and 5,000 military jobs were lost in 1974.9 Consequently, North Kingstown's smal1 businesses experienced a $15 \%$ loss in sales between February 1973 and February 1974. This decline is even more significant considering the nation as a whole met with an increase in retail sales during that same time. ${ }^{10}$ As a result, many businesses could not recover from the local recession and were forced to close.

The town has now substantially recovered from the base closing, but the town's planners are watching the future with a suspicious eye. They see the possibility of a second boom occurring as a result of industrialization at Quonset-Davisville and a large oil and gas find in Georges Bank. Planners are also concerned, as the past has shown, that the census tracts adjacent to the site will be most directly impacted. Thus, this 
paper will analyze the impacts, which were outlined in the preface, so that a second socio-economic boom-bust cycle can be avoided. 


\section{CHAPTER I}

QUONSET-DAVISVILLE: A POTENTIAL INDUSTRIAL COMPLEX

\section{Quonset-Davisville Property Ownership}

The fate of the Quonset-Davisville site is now in the hands of the State of Rhode Island, specifically the Rhode Island Port Authority and the Department of Economic Development. Their responsibility includes creating a major industrial park by demolishing comparatively useless buildings to make room for more intensive uses. The majority of the state-owned land contains old naval structures such as warehouses, storage facilities, administrative buildings, and housing units. Some of these structures have been successfully converted to private industrial uses, however, most are not worth the cost of modernizing. 11

Aside from the state-owned land, the Town of North Kingstown has acquired portions of Quonset property (see table 1). Through the Heritage Recreation and Conservation Service, North Kingstown has been successful in gaining ownership of a 166-acre golf course and a 15-acre parcel of land abutting Allens Harbor (see map 3). ${ }^{12}$ The remainder of the Quonset-Davisville land falls into two categories: Navy retained and Navy future mobilization, which includes many roadways, the airport, sections of West Davisville, and the northern area of Davisville. 


\section{QUONSET / DAVISVILLE}

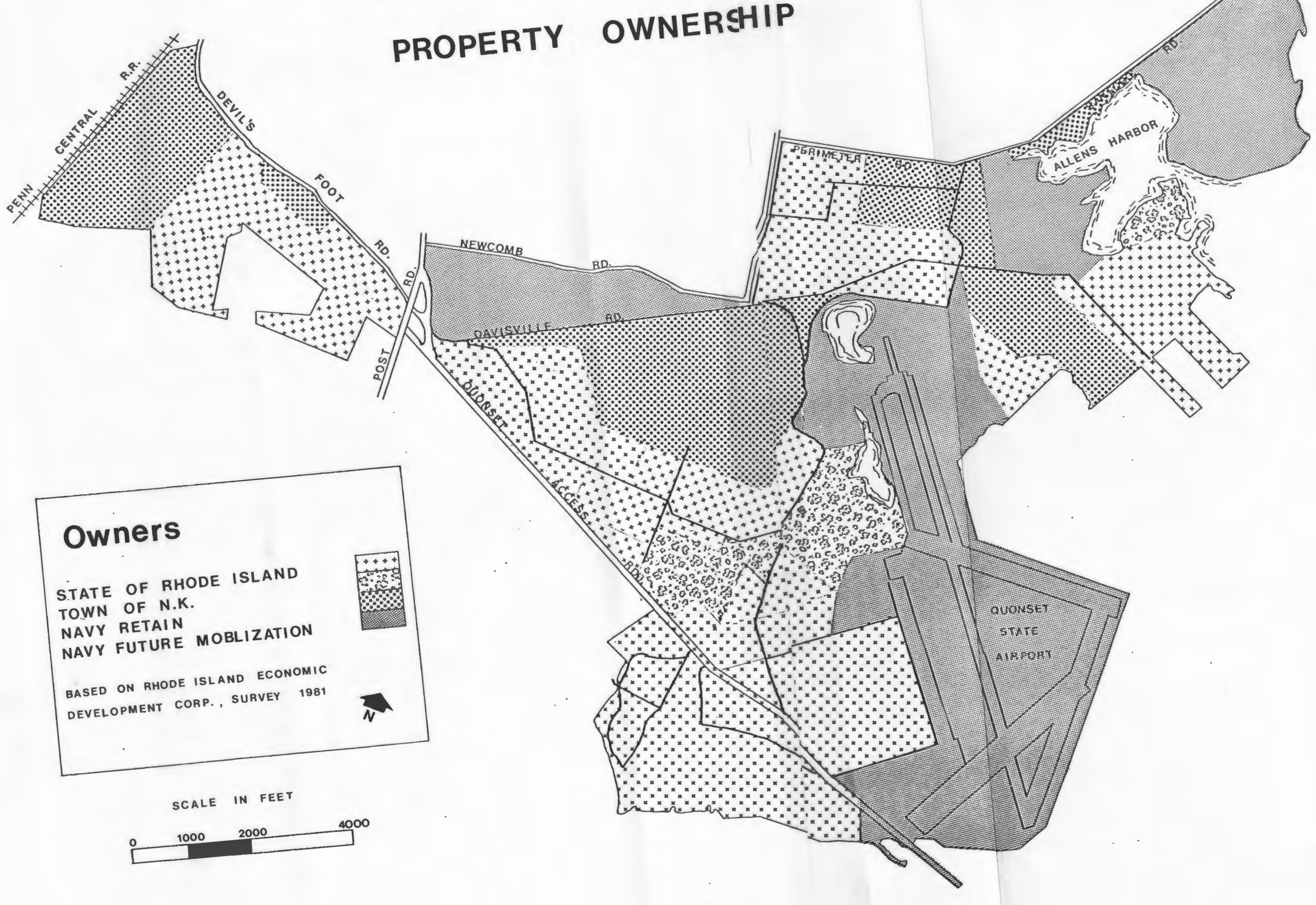


QUONSET'-DAVISVILLE PROPERTY OWNERS

Property Owners

Acres

Retained by Navy

Navy Future Mobilization

Airport

National Guard

R.I. Port Authority \& Economic Development Corp.

Electric Boat

Environmenta11y Sensitive

Developable

Sewer Treatment P1ant

Officer's Club

Admiral's House

Roads

Town of North Kingstown

Golf Course

A11ens Harbor

Total

3,000

SOURCE: Department of Economic Development memo to North Kingstown Planning Department, March 23, 1981.

\section{Development Scenarios}

The Rhode Island Port Authority and the Department of Economic Development have formulated three development scenarios for the reuse of the property (see table 2). Scenario I is based on the assumption of a high oil and gas find in the Georges Bank and Baltimore Canyon area, which would require a permanent oil support servicing base at Davisville. Scenario III, on the other hand, assumes that 
TABLE 2

QUONSET-DAVISVILLE DEVELOPMENT SCHEMES

Scenario I

Land Use

Marina

Shopping Center

Hote 1

Office Park

Technica1 Parks (2) 118

General Industry*

P1atform Fabrication

Service Bases ${ }^{+}$

419

986

\section{Scenario II}

Land Use

Marina

Shopping Center

Hote 1

Office Park

Technical Parks (3)

Genera 1 Industry

Platform Fabrication

Service Bases

Service Bases
Acres

20

29

9

66

142

$280 *$

85

355

986
Scenario III

Land Use

Marina

Acres

20

29

9

66

182

280

85

210

881

* "General Industrial" includes Electric Boat's current 150 acre development and 30 acres for Electric Boat's planned expansion.

Scenario I and I includes 85 acres of Navy retained 1 and near Dogpatch area for petroleum support industries.

+ "Service Base" refers to on-shore petroleum support activities such as supplies and crewboats, et.c.

SOURCE: Gladstone Associates, Socio-Economic Assessment of the Reuse of QuonsetDavisville, August 1977 , p. 2; Information update from Department of Economic Development, March 1981. 
little or no oil or gas will be discovered along the continental shelf, hence the oil base Eacilities currently occupying space at the Davisville piers would probably be discontinued. Scenario II, which has currently been adopted as the state's development plan, assumes a medium oil and gas find that will require an industrial mix of on-shore petroleum support facilities, warehousing, manufacturing, and other labor intensive and high-paying, skilled jobs. Although each scenario considers different mixes of industrial and commercial uses, they do have many similarities (see maps 4-6). For example, the existing General Dynamics (Electric Boat) ship building plant is planned as the core of the industrial park in each of the three plans. Electric Boat will then be surrounded by a transition zone of mixed intensity land uses, which gradually decrease in intensity as they move away from the plant. There will also be areas which would essentially maintain the same uses from scheme to scheme, such as wet lands, salt marshes, the golf course, the airport, and land retained by the Navy. Visual and accoustic buffering between major land uses is also in each scenario. The primary difference among the alternatives occurs in the remaining portion of the property. For instance, Scenario III advocates a large amount of recreational land, whereas Scenario I plans for only a small amount for this use.

\section{Site Facilities and Improvements}

Aside from Quonset-Davisville occupying a good market location, the primary reason for the state's interest in 


\section{QUONSET / DAVSVILLE}

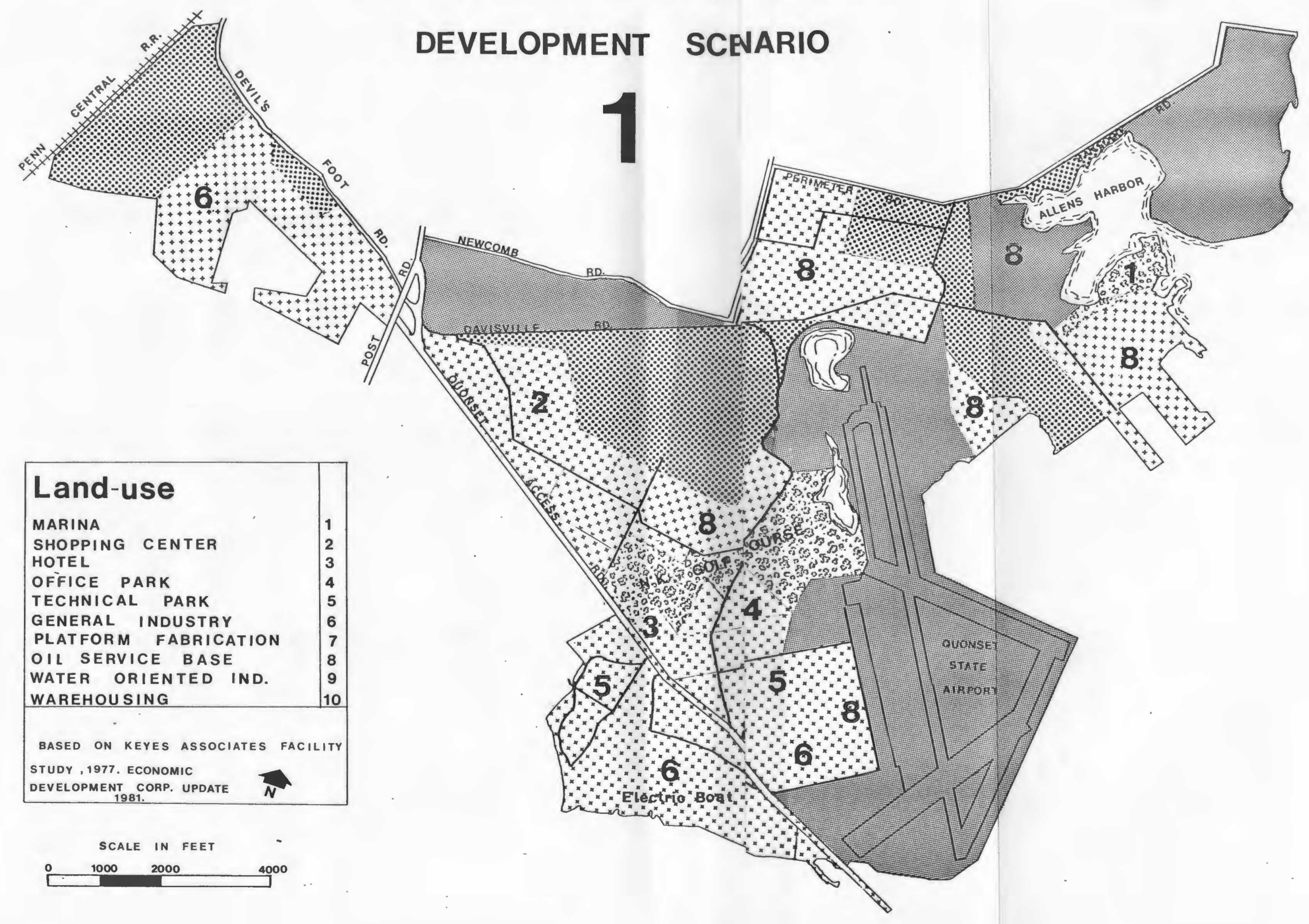




\section{QUONSET / DAVGVILLE}

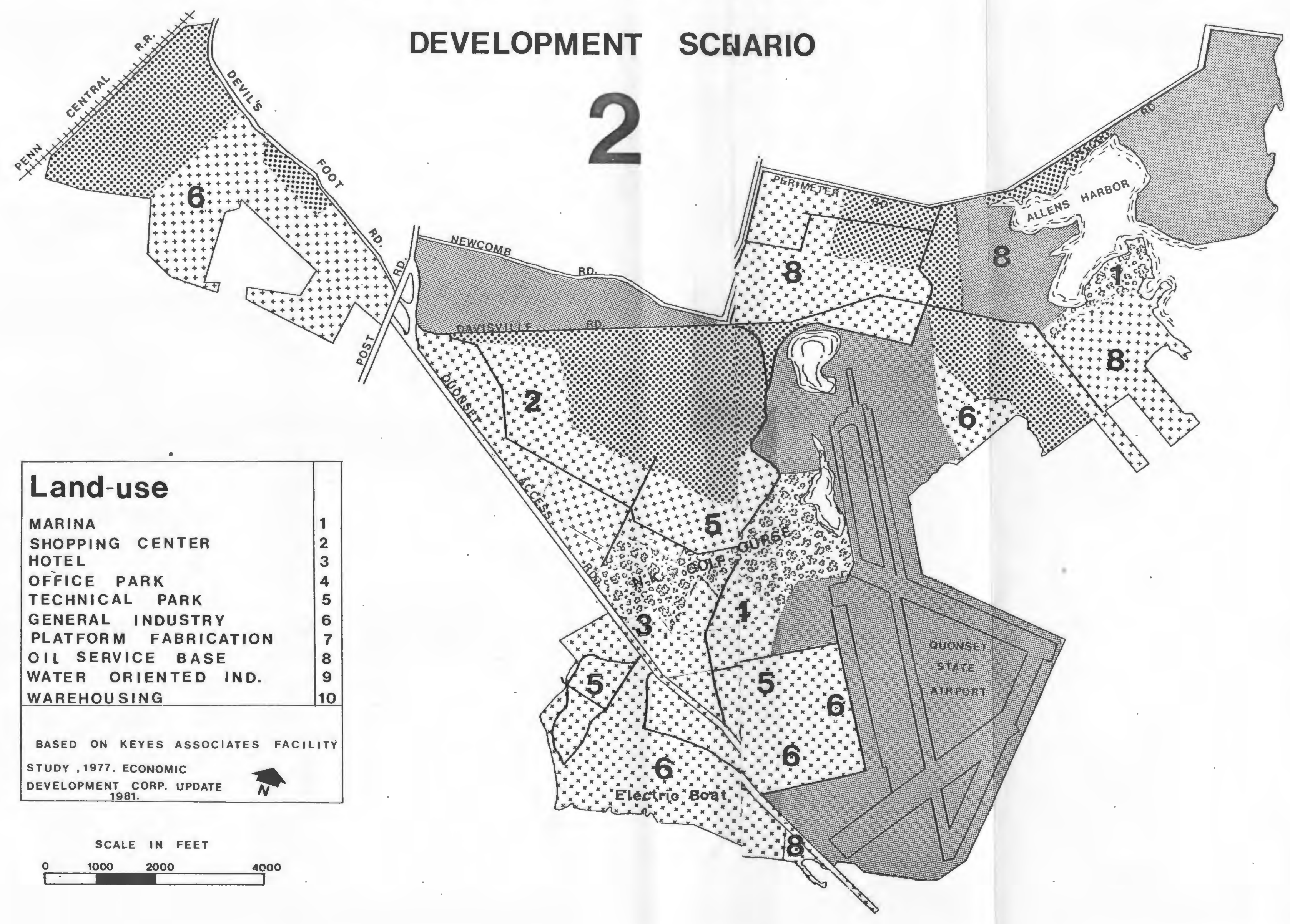




\section{QUONSET / DAVSVILLE}

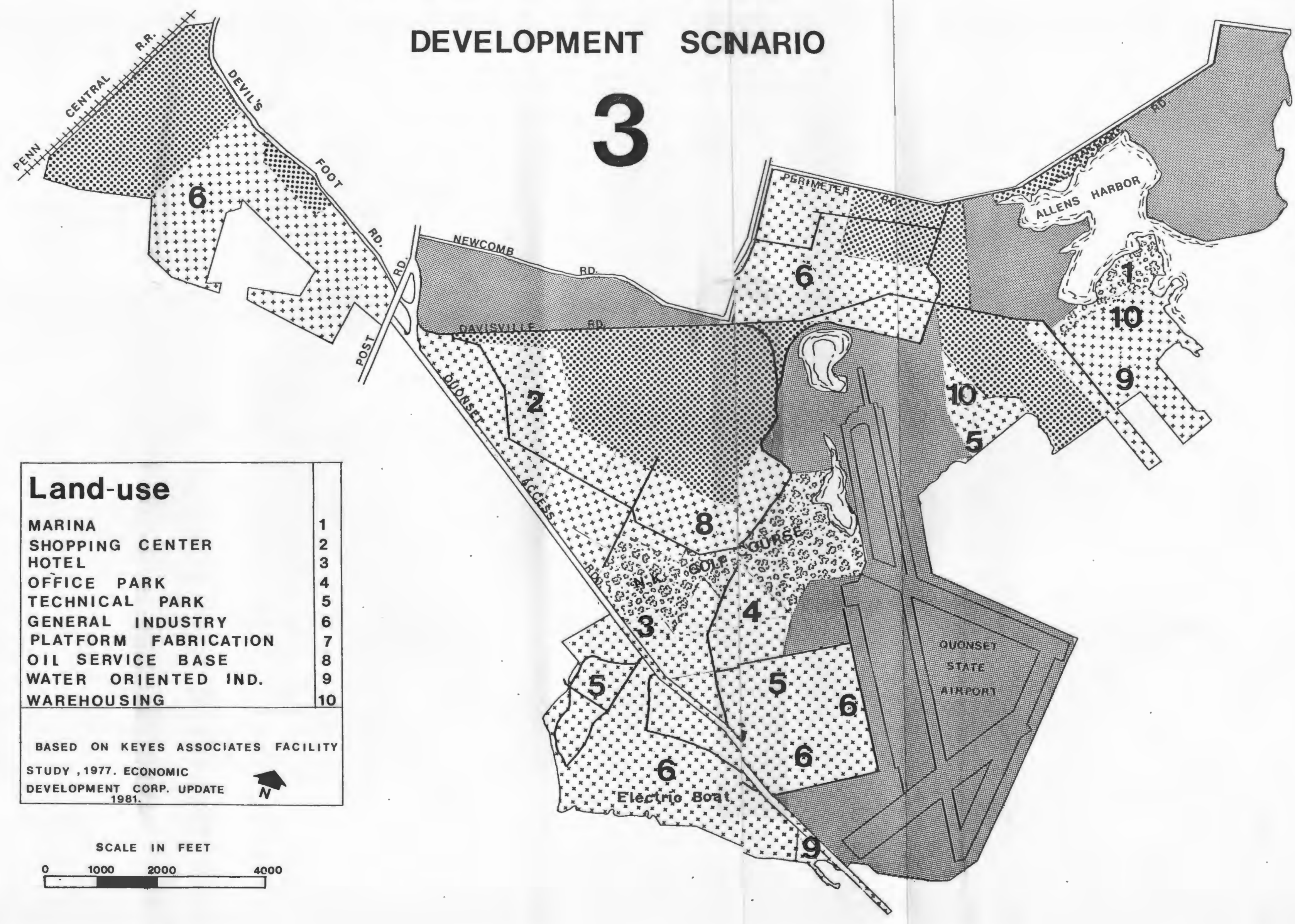


developing the property is the availability of the many utilities (see map 7). Included at the site are a primary sewage treatment plant, which is currently being upgraded to a secondary facility to properly dispose of the increase in sewage, and a distribution system that provides water from three wells located north of the base in the Potowomut watershed. The infrastructure also includes a network of roads that cover 89 acres of 1 and and elaborately connects al1 parts of the base. There is a railroad system that links areas within the site to the old Penn Central Railroad, currently used by Amtrak, at West Davisville. Other important facilities at the site are three piers, one of which is of aircraft carrier dimension, a concrete and asphalt wharf, and an airfield with four runways. All of these facilities are marketing assets which the state is gambling will attract potential firms to lease their newly purchased property.

Also, a necessary step in meeting potential industrial development demands requires that the state upgrade the QuonsetDavisville infrastructure. These requirements include improving rail spurs, sanitary sewers, storm drains, and roads to provide utilities acres to development parcels. The Department of Economic Development has estimated the man hours and costs of providing these improvements (see table 3 ).

A high oil and gas find (Scenario I) would require more intensive site development than either of the other two scenarios, especia11y Scenario III. The primary difference seems to be in the cost of providing bulkheading and new finger piers which are 


\section{QUONSET / DAV SVILLE}

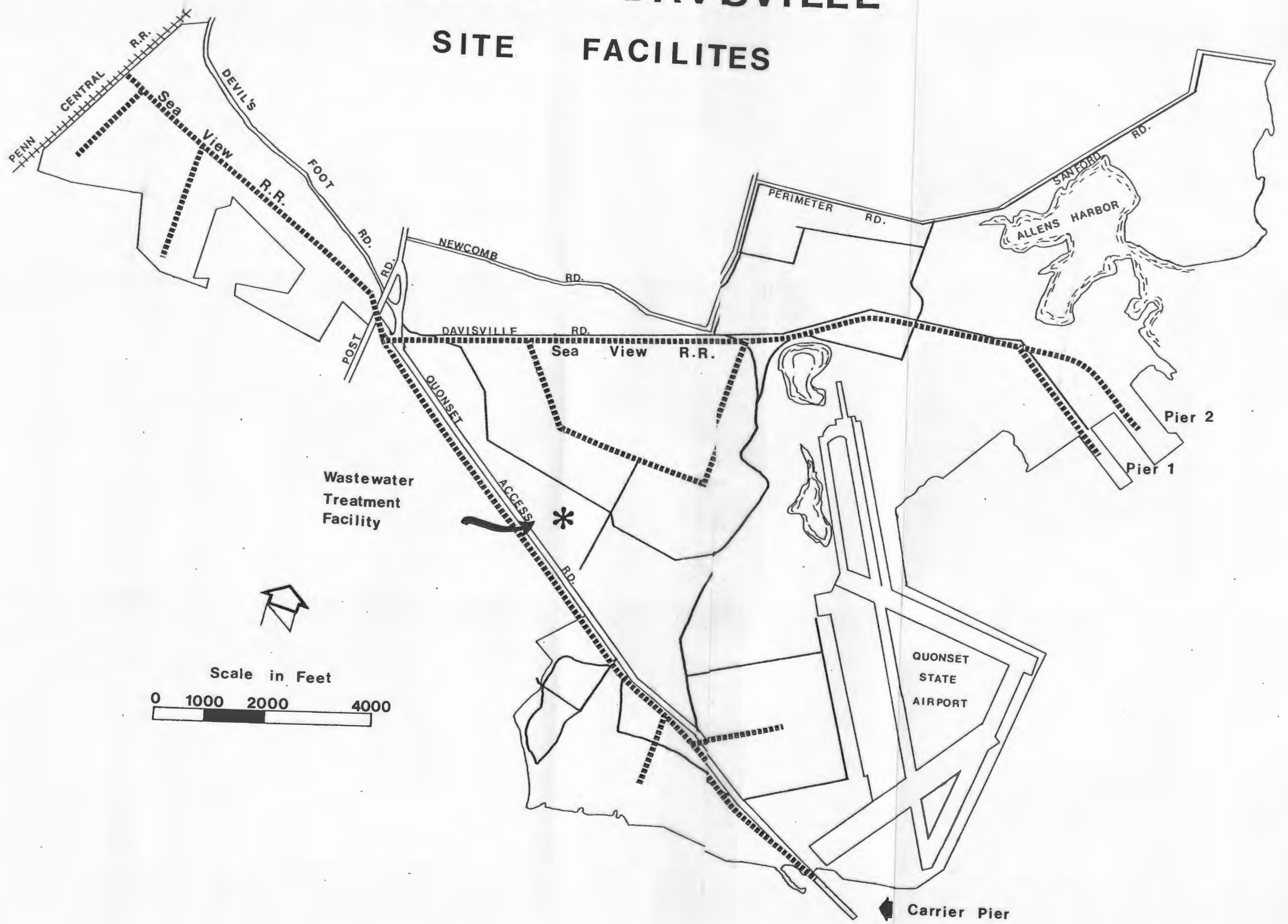


needed in Scenarios $I$ and II. These site improvements should directly benefit the construction industry which would be involved in offshore facilities and the firms which provide their services and materials.

TABLE 3

QUONSET-DAVISVILLE INFRASTRUCTURE IMPROVEMENT COSTS

Scenarios

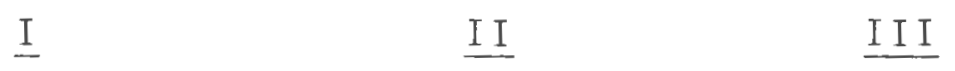

Total Construction
Costs (000's)
34,670
31,736
16,534

Estimated Labor

$$
\text { Cost }\left(000^{\prime} s\right)^{1} \quad \$ 12,135-\$ 15,602 \quad \$ 11,108-\$ 14,281 \quad \$ 5,787-\$ 7,440
$$

Construction

Employment (man

months $)^{2}$

$4,650-5,980$

$4,260-5,470$

$2,220-2,850$

Direct Construction

$$
\text { Wages }\left(000^{\prime} \mathrm{s}\right)^{3} \quad \$ 7,280-\$ 9,360 \quad \$ 6,660-\$ 8,570 \quad \$ 3,470-\$ 4,460
$$

1 Assumes total 1 abor costs is between 35 and 45 percent of construction costs.

2 Based on total labor cost of $\$ 15$ per hour and 174 hours per month.

3 Based on direct wages of $\$ 9$ per hour and 174 hours per month.

SOURCE: Keyes Associates, Quonset Point Technical Park Facilities P1an, 1977 . 
Projected Employment

The actual number of on-site employees expected once the site has been improved varies with the three scenarios (see table 4).

\section{TABLE 4}

EMPLOYMENT ESTIMATES FOR 10 AND 25 YEAR PERIODS

\section{Scenarios}

\begin{tabular}{|c|c|c|c|c|c|c|}
\hline & $\begin{array}{l}\text { High } \\
10 y\end{array}$ & $\begin{array}{l}\text { Find } \\
25 y\end{array}$ & $\begin{array}{l}\text { II } \\
\text { Medium } \\
\text { 10y }\end{array}$ & $\begin{array}{r}\text { Find } \\
25 y \\
\end{array}$ & $\begin{array}{c}\text { Low } \\
10 y\end{array}$ & $\begin{array}{l}\text { II } \\
\text { Find } \\
\quad 25 y \\
\end{array}$ \\
\hline Marina & 20 & 20 & 20 & 20 & 20 & 20 \\
\hline Shopping Center & $-\cdots$ & 330 & $\cdots$ & 830 & $\cdots$ & 830 \\
\hline Hote 1 & 105 & 105 & 105 & 105 & 105 & 105 \\
\hline $\begin{array}{l}\text { Air National } \\
\text { Guard }\end{array}$ & 205 & 205 & 205 & 205 & 205 & 205 \\
\hline Office Park & 1,000 & 2,875 & 1,000 & 2,875 & 1,000 & 2,875 \\
\hline $\begin{array}{l}\text { General } \\
\text { Manufacturing/ } \\
\text { Technical } \\
\text { Industries }\end{array}$ & 2,565 & 6,550 & 2,565 & 7,455 & 3,470 & 7,615 \\
\hline $\begin{array}{l}\text { P1atform } \\
\text { Fabrication }\end{array}$ & 1,250 & $-\cdots$ & 1,250 & $\cdots$ & $-\cdots$ & $-\cdots$ \\
\hline Service Bases & $\underline{1,270}$ & $(435)$ & 1,155 & 295 & $\ldots$ & $\cdots$ \\
\hline & 6,415 & 11,020 & 6,300 & 11,785 & 4,800 & 11,650 \\
\hline
\end{tabular}

SOURCE: Gladstone Associates, Socio-Economic Assessment of the Reuse Alternatives of Quonset Point-Davisville, August, 1977, p. 41-42.

These estimates show that in 10 years, Scenario I and Scenario II would create approximately the same number of jobs. Scenario III would lag behind because it depends on a more general employment 
mix, which would be slower to develop than the on-shore petroleum support activities of Scenarios I and II. Over the long term, though, Scenario III is expected to provide a comparable number of jobs. Contributing to this catch up are the predictions that the platform fabrication industry will be eliminated and the oil service base will be slowed as the oil activities wind down over a 25 -year period.

Just as important as the analysis of the number of employees expected on-site is the occupations of these projected employees. Separating the occupations allows a better evaluation of potential income levels of the employees. In the case of a low oil and gas find (Scenario III), a large proportion (34 percent) of the employment is likely to consist of professional and technical jobs (see appendix B). Most of these managerial and administrative positions fall into the office park category and the manufacturing and technical industries. Service workers and laborers, on the other hand, have a combined proportion of only 5 percent of the projected employment. This occupational breakdown tends to support the state's claim that there will be a large percentage of high-paying jobs created.

The only major variation among the three scenarios is that Scenario I has approximately $600-700$ less projected employees due to the reliance on the employment from the high oil and gas find. Since both Scenarios I and II are based in part at least on the expectation of a moderate-to-high petroleum find, it is important to analyze the occupational breakdown of these employees over time (see table 5). 
TABLE 5

OIL RELATED EMPLOYMENT

\begin{tabular}{|c|c|c|c|c|c|c|c|c|}
\hline & \multirow{2}{*}{\multicolumn{4}{|c|}{ IIigh Find }} & \multicolumn{4}{|c|}{$\begin{array}{l}\text { II } \\
\text { Medium Find }\end{array}$} \\
\hline & & & & & \multicolumn{2}{|c|}{ Number } & \multicolumn{2}{|c|}{$\begin{array}{l}\text { Find } \\
\text { Percent }\end{array}$} \\
\hline & $10 y$ & $25 y$ & $10 y$ & $25 y$ & $10 y$ & $25 \mathrm{y}$ & $10 \mathrm{y}$ & $25 y$ \\
\hline $\begin{array}{l}\text { Professional/ } \\
\text { Administrative }\end{array}$ & 300 & 30 & $11.9 \%$ & $6.6 \%$ & 290 & 20 & $12.0 \%$ & $6.9 \%$ \\
\hline Skilled Workers & 1,360 & 130 & $54.0 \%$ & $30.4 \%$ & 1,325 & 90 & $55.1 \%$ & $29.7 \%$ \\
\hline \multirow[t]{2}{*}{ Unskilled Workers } & 860 & $\underline{275}$ & $34.1 \%$ & $63.0 \%$ & 790 & $\underline{185}$ & $32.9 \%$ & $63.4 \%$ \\
\hline & 2,520 & 435 & $100.0 \%$ & $100.0 \%$ & 2,405 & 295 & $100.0 \%$ & $100.0 \%$ \\
\hline SOURCE : & tont & Asso & tes, & io-E & ic Ass & essn & $t$ of the & \\
\hline
\end{tabular}

The two scenarios are very similar in the number of employees and in the occupational mix. Up to the 10-year period, the skilled workers are expected to dominate this aspect of the job market with a 55 percent proportion of the total work force. However, within 25 years, when the workforcedrops off dramatically, the skilled workers will no longer be needed, and the unskilled workers will then become the major oil-related occupation at Quonset-Davisville.

The redevelopment of the Quonset-Davisville site will not on1y create approximately 12,000 on-site jobs, it is a1so expected to influence off-site employment. Included in the secondary employment market would be a variety of service activities, retail and wholesale businesses, and many establishments which would be necessary to service the firms and their employment at the site (see table 6). 
TABLE 6

ESTIMATED SPIN-OFF JOBS

Scenario

\begin{tabular}{ccccc} 
& \multicolumn{1}{c}{} & II & III \\
Year 10 & 4,000 & 4,000 & 2,900 \\
Year 25 & 6,400 & 6,900 & 6,800
\end{tabular}

NOTE: Figures used in above table are averages of the ranges of secondary jobs. Example -- Scenario I number of secondary jobs $3,600-4,500=4,000$.

SOURCE: U.S. Chamber of Commerce, What New Jobs Mean to a Community, 1973; NERBC-RALI, Tech Update 10, 1976 ; WoodwardClyde, Mid-At1antic Regiona1 Study, 1975; G1adstone Associates, Socio-Economic Assessment of the Reuse of Quonset-Davisville, August, 1977, p. 50 .

The only major difference between these estimates is that Scenario III is expected to grow slower than the other two alternatives as a result of its lack of oil-related industrial development. Over the long term, the alternatives become relatively equal as oil and gas industries begin to phase out. As we have seen in this analysis, there are only marginal differences in the three scenarios. Thus, the question arises as to why has the state decided to select Scenario II as its development plan when this scenario costs more than the other two alternatives. The deciding factor seems to be that the state's Department of Economic Development is expecting only a 
moderate oil and gas find in the Georges Bank area, and as a result, it is willing to gamble on grooming the QuonsetDavisville site for this projection. 
CHAPTER II

PROFILE AND ANALYSIS OF TARGET AREA

A Profile of Census Tract 501.01

Population Growth

The most current indicator of growth in Tract 501.01 is the population change that has occurred in the past ten years (see table 7). In 1970, there were 7,888 people in this tract, which was 26.5 percent of the town's total population. By 1980 , the number jumped to 8,981 which is a 13.9 percent increase. With a drop in the total town population, the percentage of residents 1 iving in this census tract increased from 26.5 percent to 41.1 percent. In addition, the number of housing units grew. In 1970, there were a total of 2,262 housing units and a vacancy rate of 5.3 percent; however, in 1980, there were 3,137 units and only 2.6 percent vacant. These statistics would have been even more significant had the persons per household not dropped by 20 percent in 1980 .

Land Use

Census Tract 501.01 has a variety of land uses, the most abundant of which is open space (see table 8). Residentia1 land, which comprises $32 \%$ of the area, has a large proportion (59 percent) of one acre or less size 1ots. One explanation 
CENSUS TRACT 501.01

1970 AND 1980 POPULATION AND HOUSING CHARACTERISTICS

\begin{tabular}{|l|c|c|c|c|c|c|c|} 
& Population & $\begin{array}{c}\text { Percent of Town } \\
\text { Population }\end{array}$ & $\begin{array}{l}\text { Persons } \\
\text { Per Acre }\end{array}$ & $\begin{array}{c}\text { Housing } \\
\text { Units }\end{array}$ & \multicolumn{2}{|c|}{$\begin{array}{l}\text { Occupied Housing Units } \\
\text { Unacancy }\end{array}$} & $\begin{array}{c}\text { Persons } \\
\text { Rate }\end{array}$ \\
\hline Per H.H.
\end{tabular}

11980 population of North Kingstown 21,615.

21970 population of North Kingstown 29,793.

3 Total acres in Census Tract 501.01 approximate1y 4,933.

4 Persons per household.

SOURCE: U.S. Bureau of the Census, 1970. 
TABLE 8

1980 LAND USE DATA

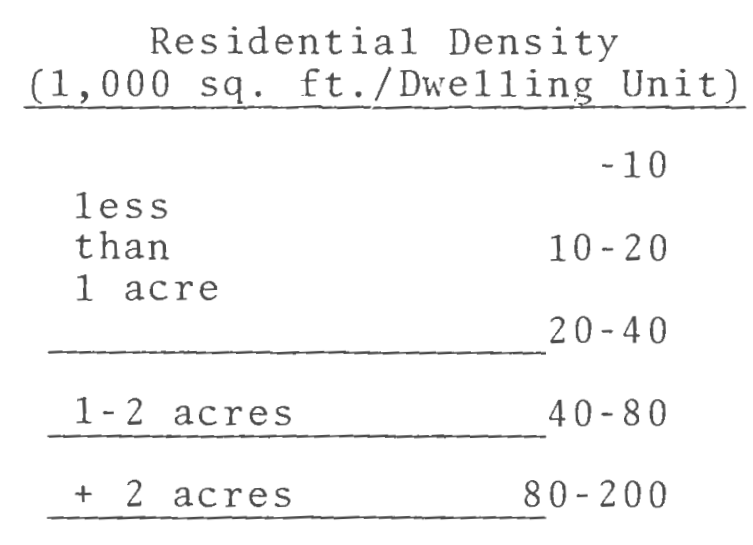

$\begin{array}{rc}\text { Census Tract } & 501.01 \\ \text { Acres } & 16 \% \\ 247 & 14 \% \\ 224 & 29 \% \\ 461 & 13 \% \\ 207 & 28 \% \\ 446 & -100 \% \\ 1,584 & 100 \text { Total Area }\end{array}$

A11 Land Uses

Residential

$1,584 \quad 32 \%$

Commercial

132

$3 \%$

Industria 1

78

$2 \%$

Mixed Commercia1/Residentia1

15

$\frac{1}{2} \%$

Institutiona 1

171

$4 \%$

Public

78

$2 \%$

Agriculture

331

$6 \%$

Commercial Recreation

208

$4 \%$

Excavation

15

$\frac{1}{2} \%$

Open Space

2,121

$42 \%$

Roads and Ponds

$\frac{200}{4,933}$

$4 \%$

$100 \%$

SOURCE: North Kingstown Planning Department Land Use Survey, Apri1 1980 . 
for this occurrence is that the subdivisions, in which these lots were laid out, were densely constructed in the $1940 \mathrm{~s}$ to house the large military populations stationed at QuonsetDavisville. Although there are only 132 acres of commercial property within this district, the majority of it is located along Post Road. This sprawling business area provides many services and goods for North kingstown residents and their neighbors. The store $\mathrm{mix}$ includes fast food restaurants, real estate firms, new and used car sales companies, a moderate sized shopping center, and many small stores. As for the 78 acres of industrial 1and, most of it belongs to the Brown and Sharpe company located at the northern most portion of the tract. There are also smaller industrial firms such as a welding company, a lumber yard, and a plastic company situated along the Amtrak Railroad line.

Included in the commercial recreation category are activities that are privately owned, including tennis clubs, health spas, golf clubs, etc. Of the 208 acres of commercial recreation land in Tract 501.01 , the majority of it can be found in the northeast corner belonging to the quidnessett Golf Club. The remainder of the 4,933 acres is distributed among other various uses including road right-of-ways and inland water bodies.

There still remains an abundant amount of open space in this northern area of North Kingstown. In fact, it is the largest use category in the tract. The majority of this land is located in the wooded central and northeast portions of the 
tract. Preliminary investigation shows that there are a few developers and 1 and owners who hold parcels of 50 acres or more. The majority of this open space belongs to small property owners. 13

Public Facilities

The largest concentration of North Kingstown residents can be found within Census Tract 501.01; consequent1y, there is a large amount of services and facilities for this area. The list of public facilities includes only those which require a relatively large expenditure of public funds and provides relatively long-term services such as municiple utilities and land acquisitions (see table 9). Since the population of this tract is dispersed over a wide area, it is of particular importance for the services and facilities to be conveniently located, as well as to be of substantial capacity (sce map 8). For instance, the three elementary schools are located within the various neighborhoods in the tract and can, as a result of their design, absorb additional student populations. In fact, each of these schools is well below its enrollment capacity.

The fire stations are also located in strategic parts of the tract. The School street Station, which provides 24-hour service, can reach any of the many neighborhoods and numerous commercial establishments in a relatively short time. Although the Quidnesset Road Station is only a volunteer facility, it does contain adequate firefighting apparatus for low level alarm fires. In addition, the water towers on Exeter and 
TABLE 9

CENSUS TRACT 501.01

PUBLIC FACILITIES INVENTORY

Schoo1s

Davisville Elementary School

Forest Park Elementary School

Quidnessett Filementary School

Davisville Middle School
Maximum October 1980

Capacity Enrollment

264

Acreage

11

10

$425-475$

294

26

$1,000-1,075$

589

Fire

Station \#3 - North End Station - Post Road and School Street

Station \#4 - Quidnessett Volunteer Station - North Quidnessett and Fletcher Roads

Public Works

Forge Road Water Tower

Parks and Recreation

Forest Park Playground

Little Red School House

Yorktown Park and Playground

Sunnybrook Drive Property

Post Office - Post Road and Newcomb Road

SOURCE: North Kingstown, Public Facilities Plan, 1981 (Draft). 
:ENSUS TRACT 501.01

\section{PUBLIC FACILITIES} ELEMENTARY SCHOOL MIDDLE SCHOOL FIRE STATION WATER TOWER

PARKS AND RECREATION
西

wt

*
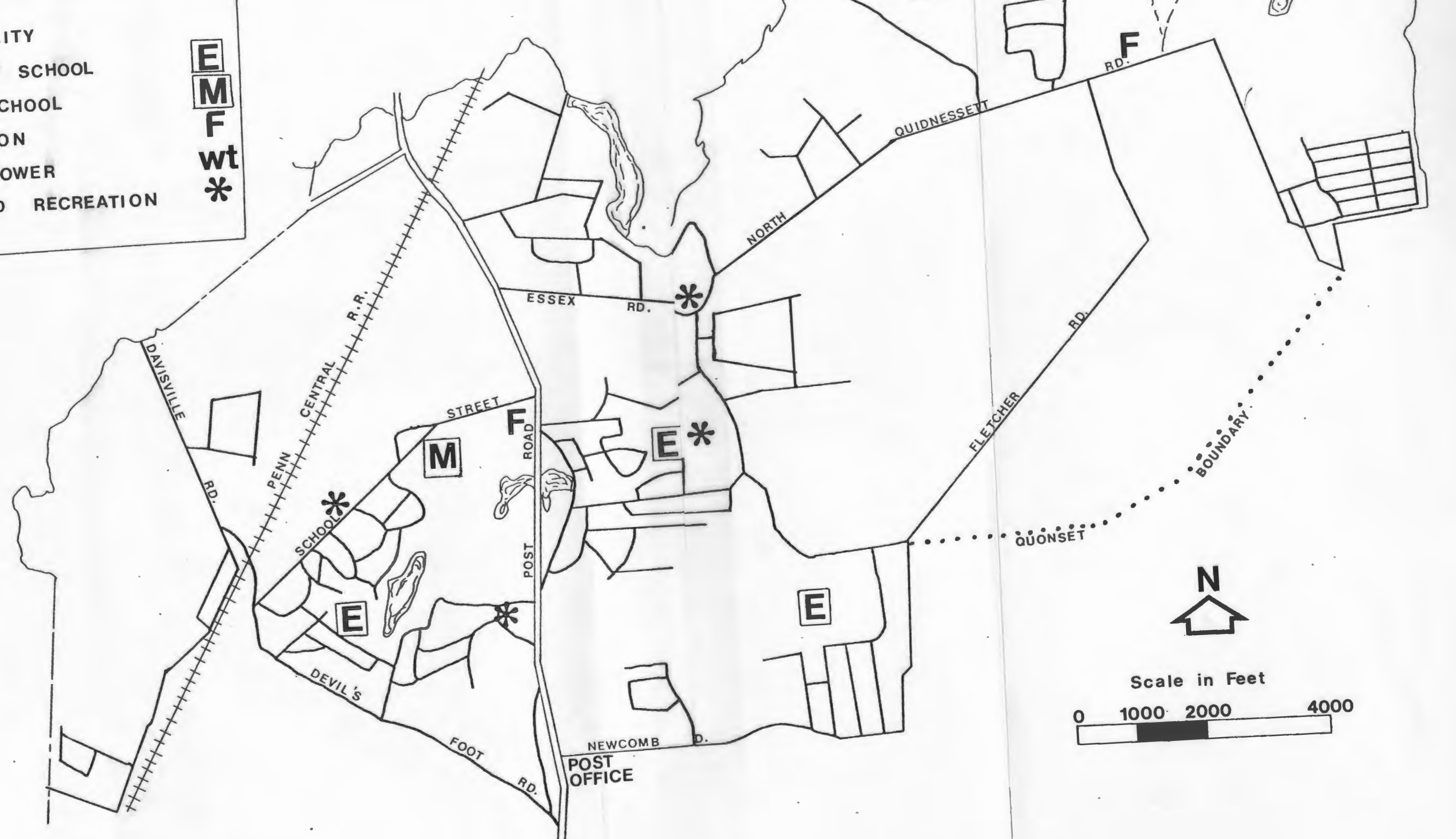

Scale in Feet

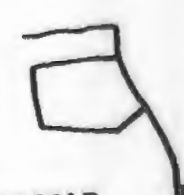

POST

$0 \quad 1000 \quad 2000$ 4000 
Forge Roads store water for the northern portion of the town. Assuming Tract 501.01 has an average amount of commercial and industrial activities, then the national water consumption standards of 100-125 gallons of water per person per day will apply. 14 That is, the 8,981 people in this tract would currently consume between $898,400-1,123,250$ gallons per day.

There are also a few public parks and playgrounds available to the residents of this area. Two of the facilities, Forest Park and the Little Red Schoolhouse, are directly related to elementary school counterpart, although the latter has been recently closed. The Yorktown Park, which has just been purchased by the town, is planned as an active neighborhood park and playground facility. The town property at Sunnybrook Drive is a two acre parcel of open space located within a moderate size residential subdivision. Postal service is provided for this area of town through a trailer situated at the corner of Post and Newcomb Roads. A permanent site is currently being sought.

Census Tract 501.01 , which is a relatively large area of North Kingstown, is already encountering development pressure now that the redevelopment of Quonset-Davisville has begun. This growth, however, is not expected to be confined to the northern portion of the town. Consequently, the area abutting the site's southern perimeter, Census Tract 501.02 , shall be examined in the same manner as its northern counterpart. 
FUTURE LAND DEVELOPMENT PRESSURE

(Census Tract 501.01)

Methodology

Determining what changes might occur in the target area (Census Tracts 501.01 and 501.02 ) as a result of the redevelopment of Quonset-Davisville requires an analysis of the number of new employees from the industrial site that are likely to reside within the target area. Consequently, a multi-step procedure has been designed to arrive at this number.

The first step in the process is to determine the amount of developable land, and its current zoning, so that an estimate of the number of potential house lots can be made. It is difficult, however, to determine how many of the possible house lots would or could be utilized in the future. As a result, three different development options were formulated to provide a broad perspective of what could occur in the future.

Option one is based on the assumption that 100 percent of the possible house lots will be developed in 25 years. Option two takes into account the fact that there will be legal constraints such as zoning, subdivision and deed restrictions which would limit some lots from being developed. Therefore, in option two, it will be assumed that only 75 percent of the possible house lots will be built on in 25 years. The thiri option recognizes the legal restrictions of land development, as stated in option two, and also takes into consideration that many suburban property owners build houses on lots that are much larger than required under zoning regulations. Subsequently, option three 
assumes that on 1 y 50 percent of the potential house lots in each census tract will be developed.

Once the number of house lots for each of the three development options have been determined, it is then possible to calculate the number of residents and school children expected to reside in each of the two census tracts. Again, for a broad perspective of what is likely to occur over 25 years, the three alternatives will be used in this analysis. In addition to looking at the change in population, there will be a brief discussion on the municipal costs and revenues associated with the various types of residential housing. Final1y, the impacts on the schools within the target area, resulting from the projected population growth, will be evaluated.

Constraints to Land Development

Land that is currently developed is not likely to be significantly changed in the next 20 years; rather, it is the vacant land which will undergo a metamorphosis as a result of the Quonset-Davisville development pressures. The categories of land considered undeveloped includes open space, recreation. agriculture, and excavated property (see table 10). The majority of 2,675 acres of 1 and, a1though vacant, have particular development restrictions and 1 imitations. For instance, some 1 ands have environmental constraints to development such as poor soils, steep slopes, wet areas, etc. To determine the extent of the constraints, three categories were used: severe, moderate, and no development constraints. Only the moderate and severe categories have specific criteria for the land evaluation (see table 11). 
TABLE 10

DEVELOPABLE LAND IN CENSUS TRACT 501.01

\begin{tabular}{|c|c|c|c|c|}
\hline Undeveloped Land & Acres & $\frac{\circ 1}{0}$ & Development Constraints & Acres \\
\hline Open Space & 2,121 & $42 \%$ & No Constraints & 578 \\
\hline Recreation & 208 & $4 \%$ & Moderate Constraints & 1,132 \\
\hline Agriculture & 331 & $6 \%$ & Severe Constraints & 965 \\
\hline \multirow[t]{2}{*}{ Excavation } & 15 & $\underline{\frac{1}{2} \frac{0}{0}}$ & & 2,675 \\
\hline & 2,675 & $52 \frac{1}{2} \%$ & & \\
\hline $\begin{array}{l}1 \text { Percent of } \\
\text { SOURCE: Nortl }\end{array}$ & $\begin{array}{l}\text { otal } \\
\text { King }\end{array}$ & $\begin{array}{l}\text { nd in } \\
\text { own } P\end{array}$ & $\begin{array}{l}501.01 . \\
\text { Department Land Use P1an. }\end{array}$ & \\
\hline
\end{tabular}

TABLE 11

DEVELOPMENT LIMITATION CRITERIA

\author{
Moderate Constraints \\ Seasonably high water table \\ High water table \\ slowly permeable soils \\ Slopes of more than 15 percent \\ Extremely stony soils \\ Wet 1 ands \\ Frost heave potential \\ Groundwater reservoir areas \\ Slopes of 8-15 percent \\ Federal flood hazard zone A \\ Groundwater recharge areas \\ Federal flood hazard zone B \\ Prime agriculture soils \\ 2 or more soil hazards \\ Areas of natural value \\ Historic areas \\ SOURCE: North Kingstown Planning Department 1980 Land-Use \\ Plan (Draft).
}


Land that has either no constraints to development or one moderate constraint is generally regarded as being environmentally safe to develop. Land having more than one moderate constraint or a severe limitation is considered rather difficult and environmentally risky to develop. (See appendix C for a description of the constraints.) The North Kingstown Planning Department has recently determined, using a composite overlay of the various constraints, that there are 1,710 acres of 1 and in this tract having no or moderate development 1 imitations. The remaining 965 acres have been shown to have severe problems.

Another restriction to land development is zoning. In many areas with large parcels of undeveloped land, there are large lot zoning requirements. In particular, the area referred to as the Pojac Point Fire District, at the northeast corner of the tract, is currently restricted by the town's zoning ordinance and by individual property deed covenants, to minimum lot sizes of 5 or more acres. The remainder of potentially developable land is divided among the various residential zoning categories, the majority of which are one and two acre lots.

Large lot zoning, such as the two acre and five acre categories found in North Kingstown, used alone can adversely affect the environment by encouraging development sprawl. AIthough the aim of large lot zoning is often to prevent the spread of subdivisions that destroy natural beauty and to slow growth, the results do not always meet the goal. Instead, growth is only slowed temporarily, and the resulting subdivisions chew up 
vast portions of the land. In addition, utilities, roads, and other necessary services are made more costly to install under their conditions.

By regulating density and segregating various land uses, the zoning ordinance acts to limit the amount of land available for residential use. Subsequently, the requirement for large lots and homes also succeeds in pricing lower income families out of the market. Hence, it is incumbent to municipalities, which zone for large lots, to make an explicit commitment to provide low and moderate income housing for local residents.

The Town of North Kingstown seems well aware of its obligation to provide housing for low and moderate income residents. Since 1979 , the town has had an active housing assistance program for elderly citizens and low and moderate income residents. 15 The Department of Housing and Urban Development has calculated North Kingstown's low and moderate income housing need to be approximate $1 y 1,400$ units. To meet this need, the town has made a commitment to provide 2.5 percent of this need each year. In comparison to other communities in the South County and West Bay region, North Kingstown ranks high in providing housing assistance.

Even though the town has two acre and five acre residential zones, there are other residential zones provided in the ordinance for more moderate-sized lots. The Neighborhood Residential zone requires 40,000 square feet per lot, and the Village Residential zone requires even less space, 20,000 square foot lots. These various sized lot restrictions reflect the town's 
desire to accommodate a diversity of living styles. The five acre zone allows an estate and country life for wealthier residents, while the much smaller 20,000 square foot Village Residential zone provides young married couples, retired citizens, and moderate families a comfortable, more suburban living environment. In addition, much of the current zoning ordinance is founded on the past comprehensive plans and special studies which have dealt with social and physical aspects of the community.

Growth Projections

The next step then is to overlay the North Kingstown Planning Department composite of constraints to development map with the current zoning classification of the land in each tract. Only land that was currently zoned for residential uses was considered in this analysis. In addition, since innovative engineering techniques and well planned site designs can be employed to overcome severe development constraints, a portion (10 percent) of the land considered to be severe limitations was allocated to the categories of developable residential land (see table 12). This percent figure is conservative and could be significantly greater if the demand for housing were strong enough.

The result of this process provides an upper limit of the number of acres available for construction of new housing units that can be constructed in the census tract under the current zoning regulations. Column (4) of Table 12 displays the approximate number of buildable acres in each of the 
TABLE 12

DEVELOPABLE LAND BY ZONING CATEGORY

CENSUS TRACT 501.01

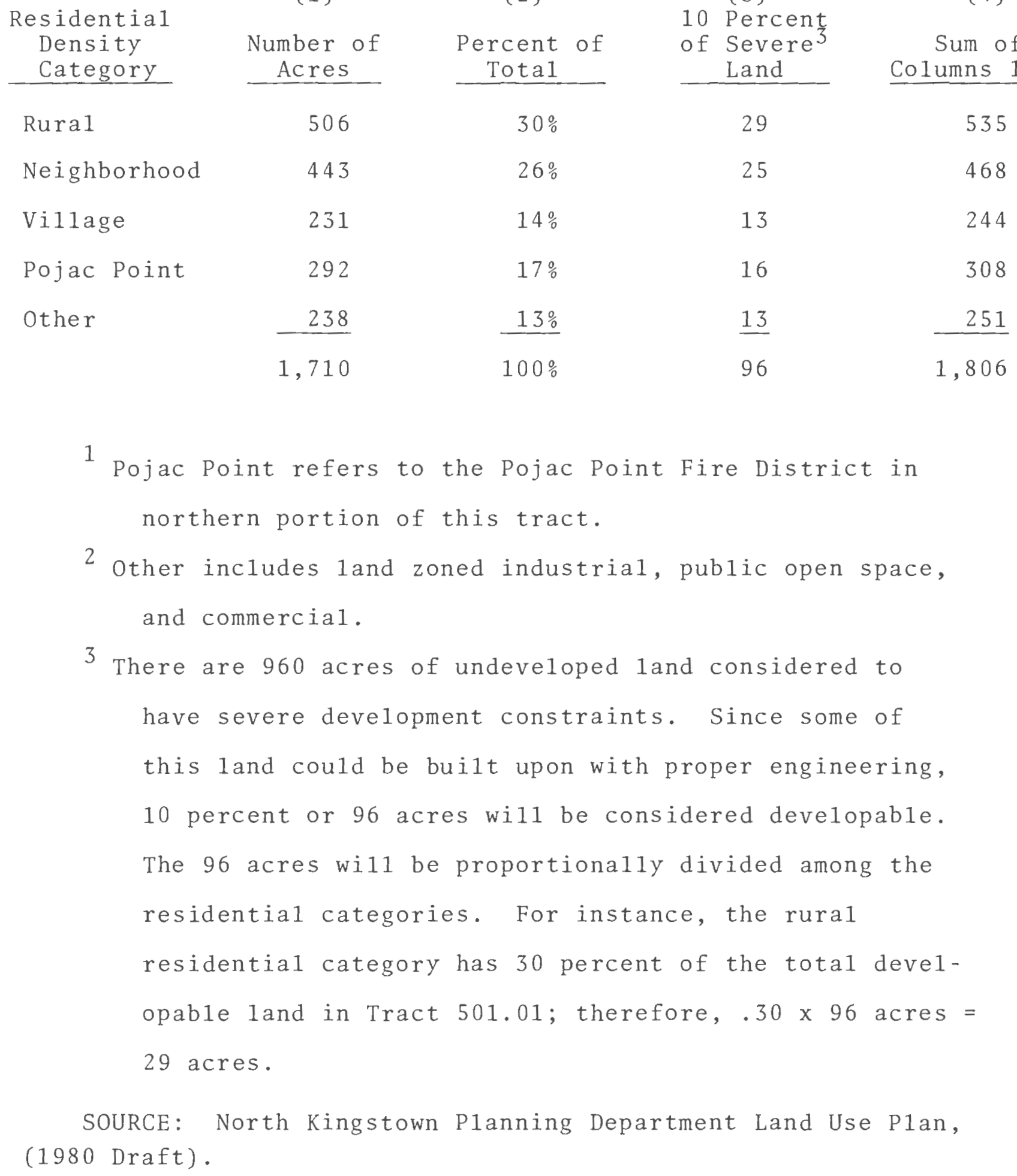

Density

Category

Rura1

Neighborhood

Number of
Acres

Percent of
Total

10 Percent

of Severe 3 Land

Village

506

$30 \%$

29

535

443

$26 \%$

25

468

231

$14 \%$

13

244

Pojac Point

292

$17 \%$

16

308

Other

$\frac{238}{1,710}$

$13 \%$

13

251

96

1,806

1

Pojac Point refers to the Pojac Point Fire District in northern portion of this tract.

2 other includes land zoned industrial, public open space, and commercial.

3 There are 960 acres of undeveloped land considered to have severe development constraints. Since some of this land could be built upon with proper engineering, 10 percent or 96 acres will be considered developable. The 96 acres will be proportionally divided among the residential categories. For instance, the rural residential category has 30 percent of the total developable land in Tract 501.01; therefore, $.30 \times 96$ acres = 29 acres.

SOURCE: North Kingstown Planning Department Land Use Plan, (1980 Draft).

(3)

(4) 
various residential zoning categories. Including the 96 acres of severely constrained 1and, Census Tract 501.01 contains 1,806 acres of developable land. The Rural Residential category contains the 1argest - 535 acres which is 30 percent of the total developable land in the tract. Village Residential, containing 244 acres, is the least abundant of the zoning classes.

To derive the approximate number of house lots possible from the 1,806 acres, it is necessary to divide the number of acres in each of the four zoning categories by their respective minimum lot requirements (see table 13).

TABLE 13

NUMBER OF POSSIBLE HOUSE LOTS UNDER CURRENT ZONING RESTRICTIONS TRACT 501.01

\begin{tabular}{|c|c|c|c|c|c|}
\hline $\begin{array}{c}\text { Residential } \\
\text { Density } \\
\text { Category } \\
\end{array}$ & $\begin{array}{l}\text { Minimum } \\
\text { Lot Size } \\
\end{array}$ & $\begin{array}{l}\text { Total } \\
\text { Acres } \\
\end{array}$ & $\begin{array}{c}100 \% \\
\text { Developed }\end{array}$ & $\begin{array}{c}75 \% \\
\text { Deve } 1 \% \text { ped } \\
\end{array}$ & $\begin{array}{c}50 \% \\
\text { Developed } \\
\end{array}$ \\
\hline Rural & 2 Acres & 535 & 268 & 201 & 134 \\
\hline Neighborhood & 1 Acre & 468 & 468 & 351 & 234 \\
\hline Village & $\frac{1}{2}$ Acre & 244 & 488 & 366 & 244 \\
\hline \multirow[t]{2}{*}{ Pojac Point } & 5 Acres & 308 & 62 & 46 & 31 \\
\hline & & 1,555 & 1,286 & 964 & 643 \\
\hline $\begin{array}{ll}1 & \text { See } \\
2 & \text { Nor } \\
3 & \text { Der }\end{array}$ & $\begin{array}{l}\text { Appendix D } \\
\text { h Kingstown }\end{array}$ & $\begin{array}{l}\text { or zoni } \\
\text { Zoning }\end{array}$ & $\begin{array}{l}\text { category } \\
\text { dinance. }\end{array}$ & finitions. & \\
\hline
\end{tabular}


According to the results of this process, there is a possibility of constructing a maximum of 1,286 housing units in this tract. It is unlikely, however, that 100 percent of this 1 and would be developed since there are many zoning and subdivision regulations that would have to be met: setback, frontage, etc. Consequently, for a more reasonable prediction of the number of possible house lots, two additional development options have been formulated. If 75 percent of the residential 1 and can be developed, there would be 964 new housing units, whereas only 643 units would be constructed under the 50 percent development option. These options provide a range from which the reader and the analyst can choose.

Determining the location of all new residential housing sites in a town is an immense task and will not be attempted here. However, it is possible to delineate the approximate location of large areas of developable land (see map 9). By utilizing the North Kingstown Planning Department composite of development constraints map, areas of 50 acres can be generally outlined. The 50-acre parcel is composed of the same developable land ratio discussed earlier in this section. That is, 10 percent of the 1 and consists of severe development constraints and 90 percent of the land has either no development limitations or moderate constraints. The areas depicted by an asterisk represent the location of more current development pressure. These plots are referred to as proposed development sites because there are subdivision plans for each of these areas which are awaiting pre-application hearings with the 


\section{ENSUS TRACT 501.01}

\section{=UTURE DEVELOPMENT SITES}

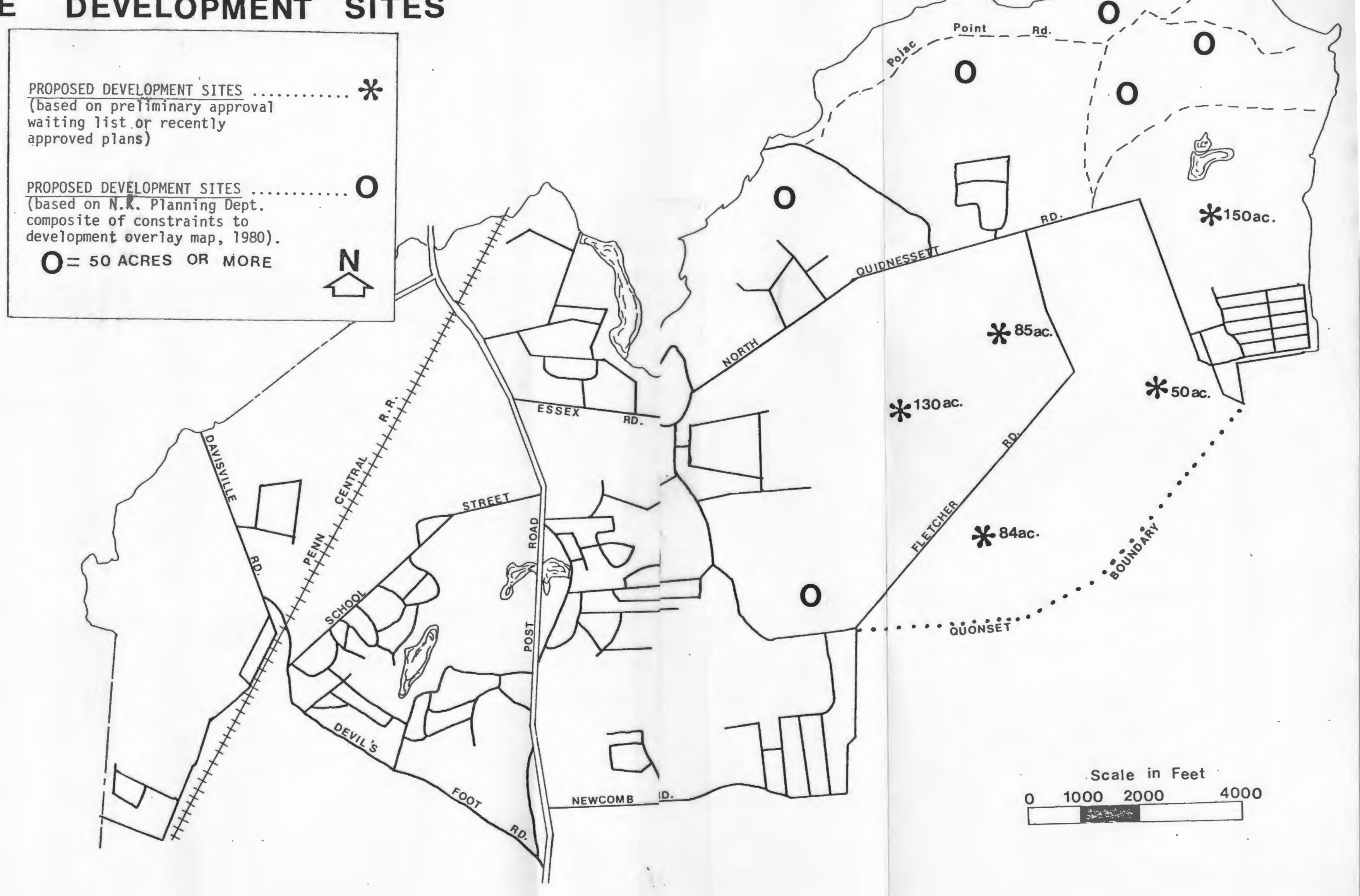


North Kingstown Planning Commission. In addition, some proposed subdivisions represented by an asterisk have recently received final approval.

The most significant aspect of the map is that the proposed and potential development sites are located in the relatively rural northern and eastern portions of the tract. The large scale development occurring in these areas is of great concern to the planners. In particular, the valuable open space, agricultural 1and, and privately-owned recreational land stands to be lost with the creation of these subdivisions. To retain these valuable community amenities, the planning department in cooperation with the planning commission has been drafting a revised cluster subdivision ordinance and holding community workshops on the cluster subdivision concepts. The objective is to permit a more diverse mix of residential development to be constructed than has been allowed under previous town zoning ordinances. The problem with the current cluster ordinance is that it limits townhouse cluster development to only one residential zone (Neighborhood Residential), and single family detached clusters to two zones (Rural Residential and Neighborhood Residentia1). The revised ordinance, it is hoped, will help preserve the rural character of many parts of town by allowing both types of cluster developments in every residential zone. 
A PROFILE OF CENSUS TRACT 501.02

Population Growth

Since Census Tract 501.02 has approximately one-half the acreage of Tract 501.01 , it is reasonable to assume that the population would also be about one-half as large. This assumption was correct in 1970 , as Tract 501.02 contained 3,369 people and Tract 501.01 had 7,888 residents (see table 14). In 1980 , however, Tract 501.02 seems to have felt the Navy's withdrawal to a greater extent than its northern counterpart since the population dropped to 1,571, and Tract 501.01 grew to 8,981. The majority of the loss occurred at the eastern portion of the tract where the military families lived.

Even though there was a dramatic decrease in population, the area did manage a slight increase in its housing stock of 8 percent. Combined with the population decrease, the housing increase caused the density to drop from 1.34 persons per acre in 1970 , to .62 persons per acre in 1980 . The indicator which truly reflects the change, however, is the vacancy rate which rose from a low of 6.2 percent in 1970 to a high of 52 percent in 1980. This increase is due to the withdrawal of the military population from 1973 to 1974 .

There are two types of vacant military housing units located along Camp Avenue, attached two-story apartments and small single-family homes. The single-family homes have recently been demolished by the Rhode Island Port Authority so that the land can be used for industry. Prior to the destruction of these housing units, the Port Authority had 
TABLE 14

CENSUS TRACT 501.02

1970 AND 1980 POPULATION AND HOUSING CHARACTERISTICS

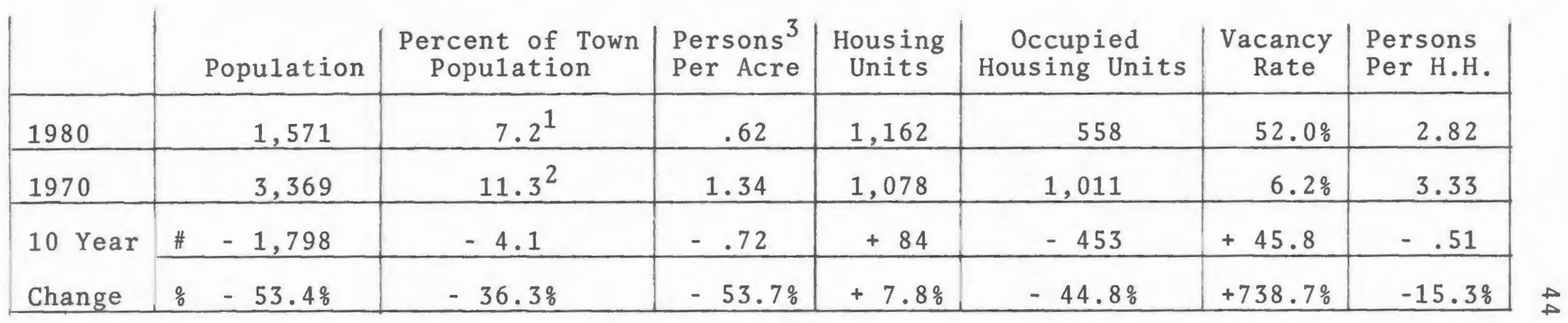

11980 population of North Kingstown 21,855 .

21970 population of North Kingstown 29,793.

3 Total acres in Census Tract 501.02 approximately 2,513.

SOURCE: U.S. Bureau of the Census, 1970 .

U.S. Bureau of the Census, 1980. Preliminary Census Data. 
administered a closed bid sale of the single family homes. The purchaser would, however, have to clear the housing unit from its site within 60 days of the sale date. Only a few people purchased these run-down homes which they dismantled and hauled away by truck. The ASQUA group, a coalition of moderate income people from around the state, were visibly angered by the demolition of the multi-family units. ASQUA contends that the Port Authority acted in bad faith, since negotiations between the Port Authority and ASQUA for the use of these units were not completed. However, the Port Authority owning the property has stated that residential units would not be a part of their Quonset-Davisville development scenario. Thus, the Authority felt that demolishing the housing units was proper as they began site improvements for potential industrial firms.

The former military multi-family housing units at Hoskins Park is currently owned by the General Services Administration. The property is actively being sought by the ASQUA coalition, so that they can renovate and inhabit the units. These a11 cinder-block units seem structurally sound, but the renovation costs would be prohibitive. These units were heated at one time by a central heating system at Quonset which is now antiquated and non-functioning. A surplus Navy housing study conducted in 1976 concluded that the cost of renovation would be prohibitive.

The other alternative for the Hoskins Park property is to demolish some or all the units and design a more energy 
efficient and less dense subdivision. Which ever proposal is accepted, there will be planning implications for the town to consider, so that the population increase associated with the development does not overwhelm the current leve1 of services provided by the town.

It should also be noted that the census tract boundaries along Camp Avenue need to be redrawn (see map 10). Since census tracts are designed to follow homogeneous neighborhood lines, it seems more realistic to include residential areas in Tract 501.02 and the industrial areas in Tract 502 which is the Quonset-Davisville Census Tract.

Public Facilities

Tract 501.02, which is sparsely populated, has few public facilities and few services available (see table 15). In fact, two of the three schools which were operational in the $1970 \mathrm{~s}$ are now being used as regional educational facilities. The Hoskins School, which was built in the 1950 s to serve the base children, is now being leased to a private educational organization that provides specialized services for children of the entire region (see map 11). The Quonset School, which was also used to educate the children at the base, is currently being leased by Roger Williams College and the North Kingstown Regional Health Center. The only functional school in this tract is Stony Lane Elementary, which is located on a 14 -acre parcel of land adjacent to the Amtrak Railroad line. The 1980 enrollment of 389 students is only 89 percent of its capacity. The other public facilities in Tract 501.02 include the pumping station 


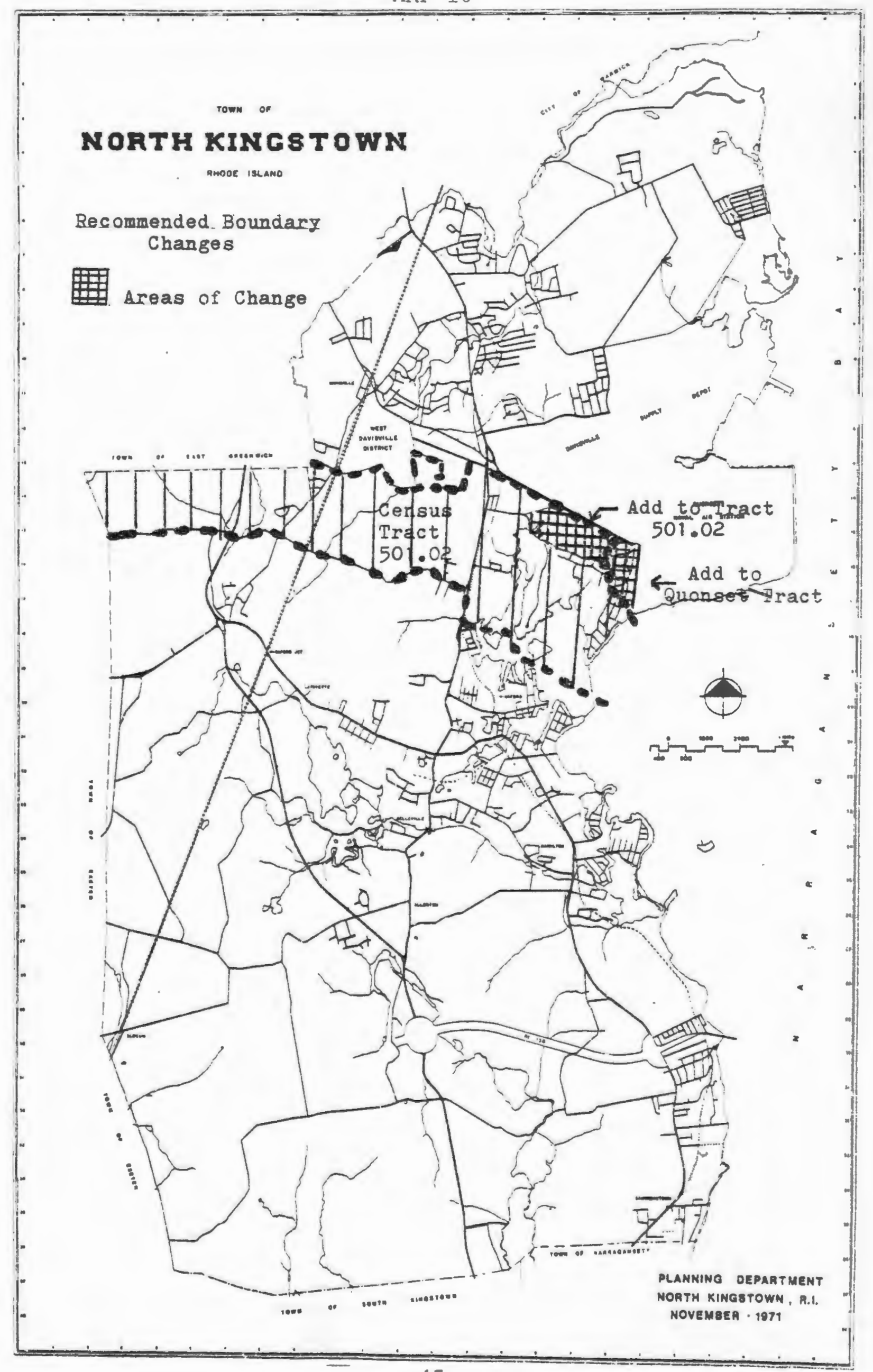




\section{CENSUS TRA;T 501.02}

\section{PUBLIC ICILITIES}

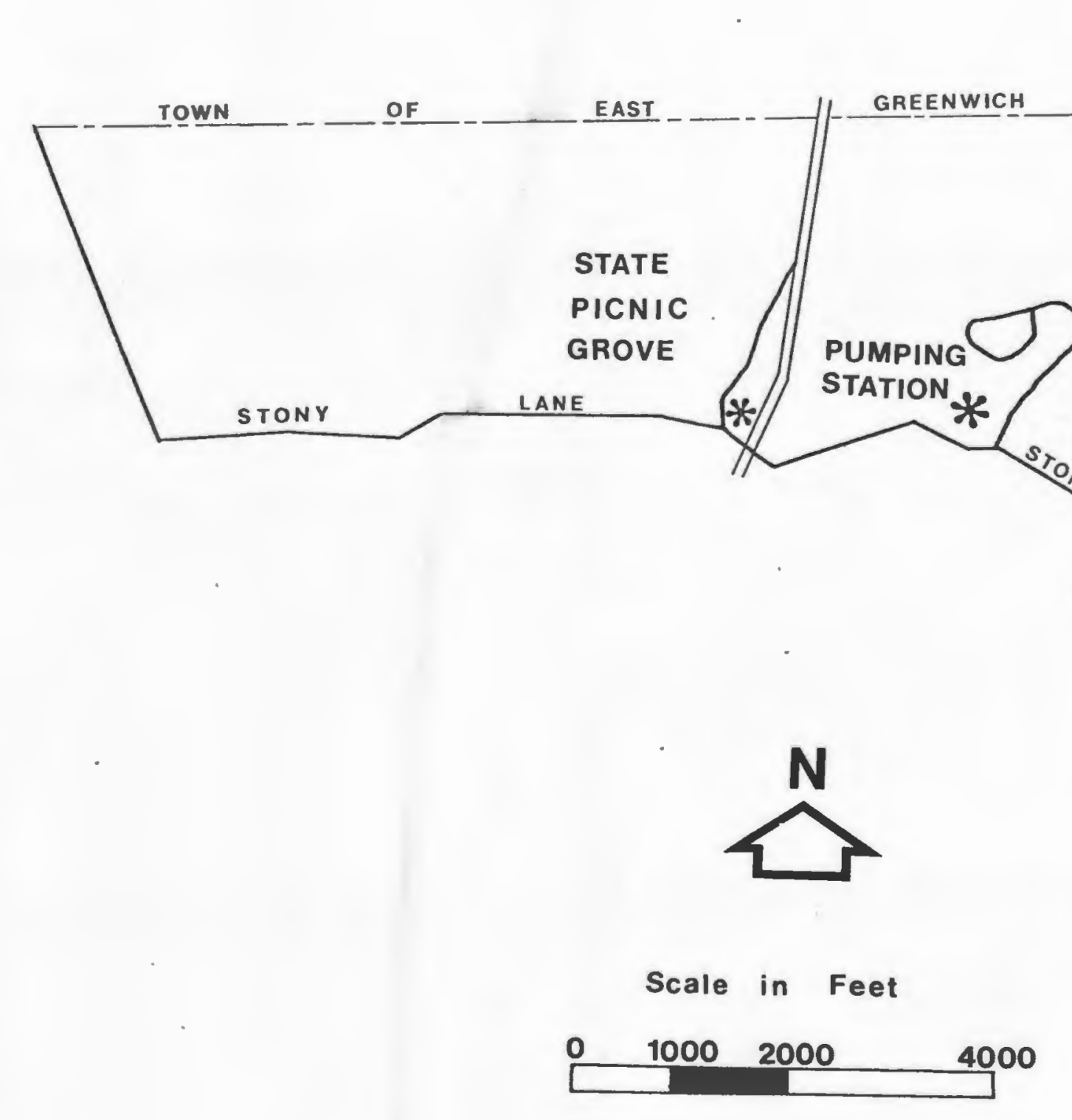


on Stony Lane and the picnic groves and rest area at Stony Lane and Quaker Lane.

TABLE 15

CENSUS TRACT 501.02

PUBLIC FACILITIES INVENTORY

Schools

Stony Lane Elementary School

Hoskins Park Schoo1

Quonset Schoo1

Pub1ic Works

Stony Lane Pumping Station

Parks and Recreation

State of Rhode Island Picnic Groves - Quaker Lane and Stony Lane

SOURCE: North Kingstown Public Facilities Plan.

Land Use

There are approximate1y 575 acres of residentia11y developed 1 and in Tract $501.02,62$ percent of which are situated on lots of less than one acre (see table 16). The relatively high percentage of lots of 10-20 thousand square feet reflects the amount of older Navy developed housing and the new townhouse developments in the eastern portion of this tract. Although only a small amount of the hundreds of Navy housing units have been rehabilitated, and consequently 
TABLE 16

1980 LAND USE DATA

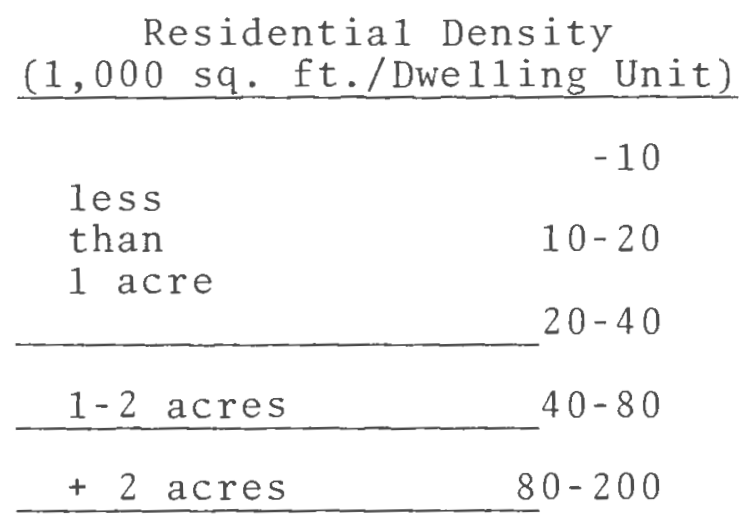

$\begin{array}{rr}\text { Acres } & \begin{array}{c}\text { Census Tract } \\ \text { Percent of Total Area }\end{array} \\ 29 & 5 \% \\ 180 & 31 \% \\ 150 & 26 \% \\ 51 & 9 \% \\ 166 & 29 \% \\ 575 & -200\end{array}$

A11 Land Uses

Residential

575

$23 \%$

Commercial

66

$3 \%$

Industrial

10

$\frac{1}{2} \%$

Mixed Commercia1/Residential

14

$1 / 2 \%$

Institutional

5

Public

40

$2 \%$

Agriculture

122

$5 \%$

Commercial Recreation

58

$2 \%$

Excavation

62

$3 \%$

Open Space

1,352

$56 \%$

Roads and Ponds

120

$5 \%$

2,425

$100 \%$

SOURCE: North Kingstown Planning Department Land Use Servey, Apri1, 1980 . 
occupied, the expectation is for private ownership of all this property to provide needed civilian housing. ${ }^{16}$ The remaining 38 percent of the residential land of this tract is considered to be large lot and can be found in the western portion, along Stony Land and old Baptist Road.

A comparison of both tracts shows that residential 1 and occupies only 23 percent of Tract 501.02 , which is 9 percent less than in Tract 501.01 . Open space which is the dominate land use category in both tracts, attributes for 56 percent of the southern tract. Although only 3 percent of the 1 and in the target area is used for commercial activity, it's presence is more obvious than the other uses because these uses are sprawled along Post Road and Quaker Lane. The business activities range from large supermarkets to small convenient stores. Agricultural land covers only 5 percent of Tract 501.02; most of it is found in large parcels along stony Lane. Similarly, the commercial recreation land consists of two golf clubs in the western area of the tract. The percentage of land used for public purposes seems to be equal in the two census tracts, 2 percent, with the majority of the property being associated with schools. Land use activities of less abundance include industrial, mixed use, and institutional. The remainder of the property in Tract 501.02 is part of the road system and the inland water bodies. 
FUTURE DEVELOPMENT PRESSURE

(Census Tract 501.02 )

Constraints to Land Development

Land considered susceptible to future development pressure, similar to the categories for Tract 501.01 , includes open space, commercial recreation, agriculture, and land that has been excavated, which amounts to a total of 1,595 acres (see table 17). Analysis of the undeveloped land indicates that there are approximately 822 acres considered feasible for development. This leaves 772 acres, or 49 percent, unsuitable for development. (The criteria used in determining the extent of development constraint is the same as used for Census Tract 501.01 in Table 11.)

\section{TABLE 17}

\section{DEVELOPABLE LAND IN CENSUS TRACT 501.02}

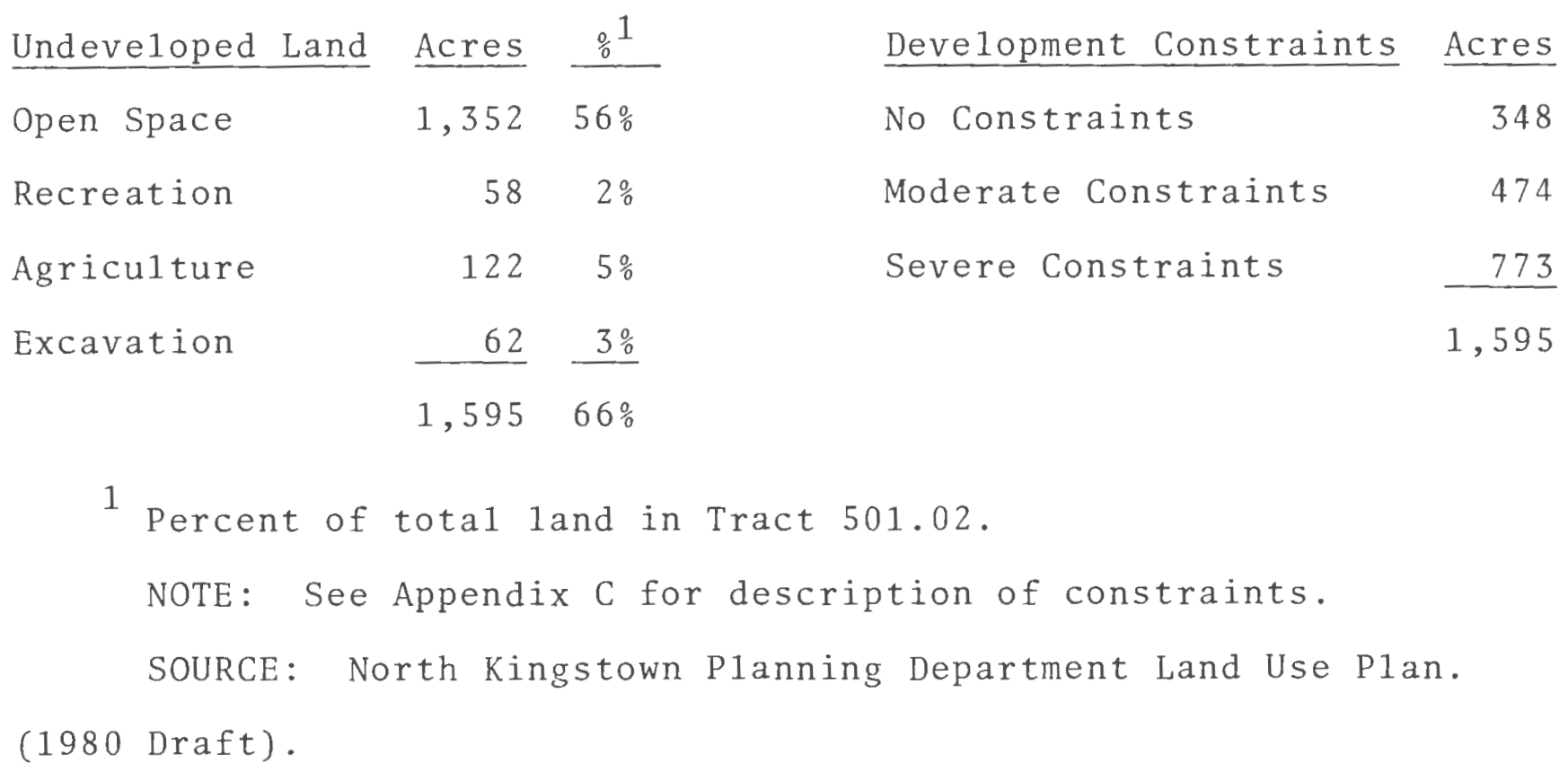


Unlike the very large lot zoning restrictions on much of the undeveloped 1 and in Tract 501.01 , Tract 501.02 is current1y zoned more moderately, with most housing lots ranging from 20,000-80,000 square feet.

Growth Projections

The method of determining the probable number of house lots used for Census Tract 501.01 can also be used for Census Tract 501.02, which is adjacent to the southern border of Quonset-Davisville (see table 18). There are, however, major differences between the two census tracts; the most obvious being the lack of a five acre zone in the southern tract. In addition, there is almost three times the amount of Neighborhood Residential 1and in Tract 501.02 as in Tract 501.01 . Since Tract 501.02 has a relatively large amount of land zoned Neighborhood Residential, which requires one acre minimum lot sizes, there is a possibility of 573 housing units being constructed in this area of North Kingstown (see table 19). Overa11, it might be possible to construct 813 house lots on the 869 developab1e acres in Tract 501.02 . The 75 percent and 50 percent development options project that there will be considerably fewer housing units constructed in this area of town due to Quonset-Davisvil1e redevelopment.

Even when combining the maximum number of housing units (100 percent development option) for the two census tracts $(1,286+813=2,099)$, the total still falls considerably short of the 3,146 total housing units expected to be developed in North Kingstown over 25 years. It should be pointed out that 
TABLE 18

DEVELOPABLE LAND BY ZONING CATEGORY

CENSUS TRACT 501.02

Residential Density Category

Rura1

Neighborhood

Village

other
(2)

Number of
Acres

216

528

56

$\frac{22}{822}$

Percent of
Tota 1

$26 \%$

$64 \%$

$7 \%$

$\frac{3 \%}{100 \%}$

(3)

10 Percent of Severe Land

19 Acres

45 Acres

5 Acres

2 Acres

71 Acres
(4)

Sum of Columns $1 \& 3$

235

573

61

$\frac{24}{893}$

1 There are 710 acres of undeveloped 1 and considered to have severe development constraints. Ten percent has been proportional1y divided amongst the categories.

SOURCE: North Kingstown Planning Department Land Use Plan. (1980 Draft).

TABLE 19

NUMBER OF POSSIBLE HOUSE LOTS UNDER CURRENT ZONING RESTRICTIONS CENSUS TRACT 501.02

\begin{tabular}{|c|c|c|c|c|c|}
\hline $\begin{array}{c}\text { Residential } \\
\text { Density } \\
\text { Category } \\
\end{array}$ & $\begin{array}{l}\text { Minimum } \\
\text { Lot Size }\end{array}$ & $\begin{array}{l}\text { Tota } 1 \\
\text { Acres } \\
\end{array}$ & $\begin{array}{c}100 \text { Percent } \\
\text { Developed }\end{array}$ & $\begin{array}{l}75 \text { Percent } \\
\text { Developed } \\
\end{array}$ & $\begin{array}{l}50 \text { Percent } \\
\text { Developed }\end{array}$ \\
\hline Rura 1 & 2 Acres & 235 & 118 & 88 & 59 \\
\hline Neighborhood & 1 Acre & 573 & 573 & 430 & 286 \\
\hline Village & $\frac{1}{2}$ Acre & 61 & 122 & 92 & 61 \\
\hline & & 869 & 813 & 610 & 406 \\
\hline
\end{tabular}


these projections represent only the population increase related to Quonset-Davisville redevelopment, and they do not account for growth that could occur naturally. The 16 percent growth rate that occurred from 1970-1980 is a result of natural growth, since it cannot be attributed to any one source (see appendix A). Consequently, the other portions of North Kingstown are likely to feel the pressure of residential development. In fact, the western area of North Kingstown, known as slocum, is a combination of flat agricultural tracts and abundant wooded areas which are, in large part, available for residential development. Further study of the remaining parts of the town must be conducted to determine how much development is possible and where it is likely to occur.

The location of current and potential areas of subdivision within Census Tract 501.02 are shown in Map 12. The two most prominent land uses susceptible to development pressure seem to be golf courses and agricultural land. Of the three privately owned courses, two are actively being planned for development. One of these potential development sites is in Census Tract 501.02 and the other is located in Tract 501.01 . The large parcels of agricultural land are also facing conversion. Most of the agricultural land in the southern census tract is located along Stony Lane and is shown on Map 12 as being subject to future subdivision pressure. The reasons why agricultural property is so attractive to developers are that the land is usually flat, cleared of trees, and containing ample road frontage. All of these factors add to the value of residential property and reduce site improvement costs. 


\section{CENSUS TRACT 501.02}

\section{FUTURE DEVELPMENT}

SITES

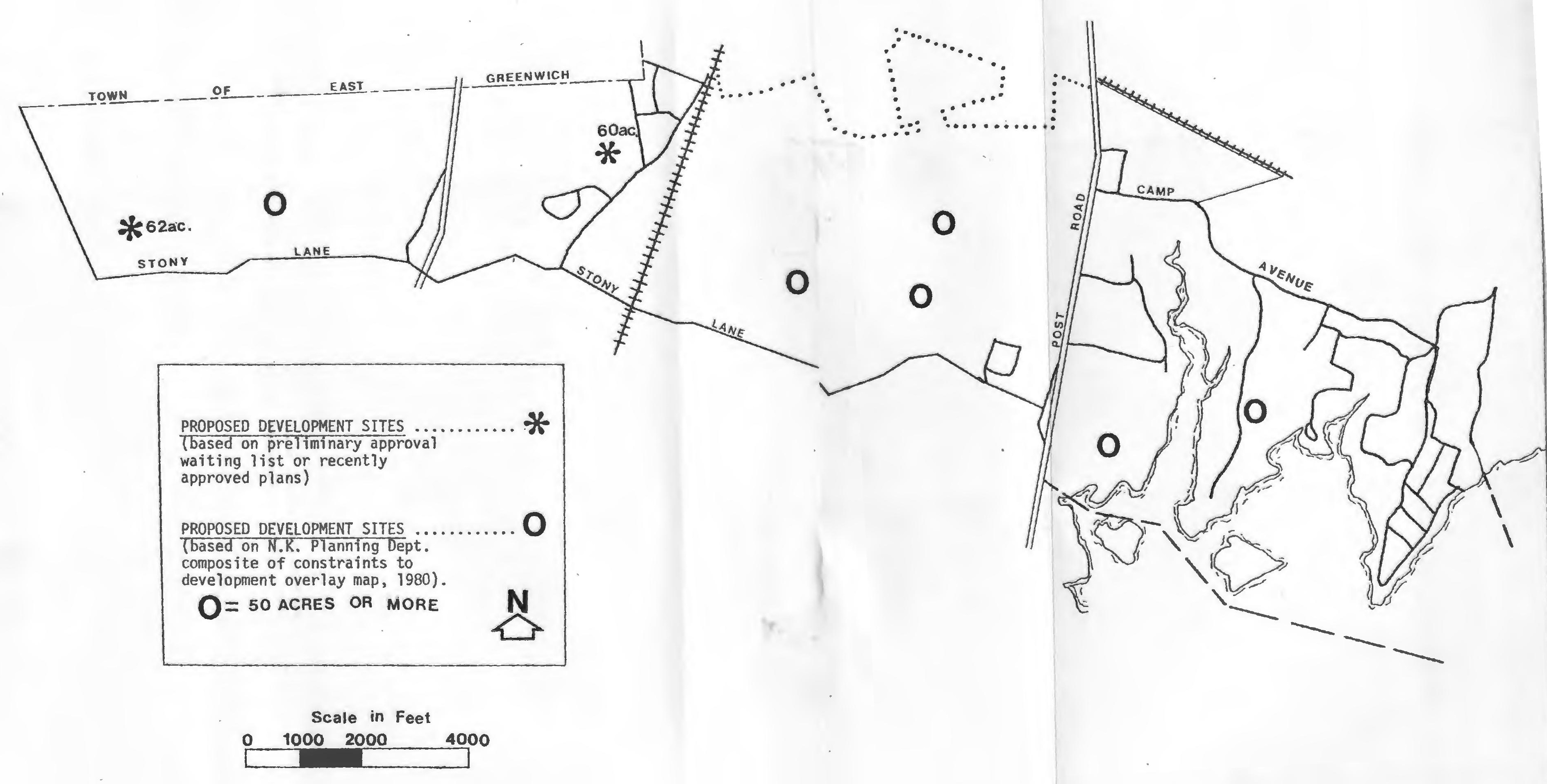


A majority of developable land in Tract 501.02 is located in the areas west of Post Road. Most of the recent development, however, has occurred in the eastern portion of this tract, along the shores of Wickford Cove. Since developers can make a larger return on their investment by constructing waterfront housing, there has been less demand for property in the western section of town. Unfortunately, the prime waterfront land is al1 but used up and planners can expect to see increased development pressure in the more rural areas of this tract and the entire town. 
CHAPTER 3

IMPACTS ON MUNICIPAL EMPLOYMENT AND BUDGET

Chapter three consists of five sections. The first deals with the agreement between the Town of North Kingstown and the State of Rhode Island concerning Quonset-Davisville redevelopment. Section two discusses the particular methodology used in determining the number of future municipal employees needed in North Kingstown due to the growth of Quonset-Davisville. The third and fourth parts of this chapter project the employment increases needed in each of the various municipal functions. Finally, section five analyzes the actual municipal costs and revenues associated with the types of residential development mixes .

The Agreement

An agreement between the Town of North Kingstown and the Rhode Island Port Authority and Economic Development Corporation was signed on April 28, 1980, for the purpose of resolving matters concerning the future of the Quonset-Davisville site. ${ }^{17}$ After the Naval Base closed in 1974, discussions between the town and the State of Rhode Island began to evolve. The inquiry focused on the roles of the two parties in the shaping of QuonsetDavisville's future. Both the federal government's Services Administration and the Rhode Island Port Authority felt that the 
town was responsible for providing services to the site since it is within the town's boundaries. ${ }^{18}$ on the other hand, the North Kingstown planners recommended to the Town Council that the services should not voluntarily be provided. ${ }^{19}$ The arguments also revolved around the land acquisition requests for the golf course, the marina, and part of the Davisville piers. In 1979 , the GSA decided to appease both sides by awarding the golf course and the marina to the town and the pier area to the state. This settlement unblocked the way for further negotiations which eventually led to the signing of the agreement in 1980 . The agreement stipulates that North Kingstown will be responsible for providing police and fire protection and highway maintenance for the site in return for revenues in 1 ieu of property taxes. In addition, sewage disposal, water supply, solid waste disposal, and management of heat and power supply are not considered municipal services within the context of the agreement. However, if any of the former mentioned services are generally provided to the residents of North Kingstown, they will 1ikewise have to be provided to the Quonset-Davisville site by the town. 20

The tax payments for the municipal services are specifically stated in the agreement. The Port Authority is required to pay the town $\$ 75,000$ each year for its occupation of particular land parcels on the industrial site. 21 The property leased to the General Dynamics Corporation (E.B.) by the Port Authority under a 1974 agreement sha11 pay the town the sum of $\$ 462,756$ each calendar year. In addition, property leased by E.B. under a 1978 agreement will pay the town a sum of $\$ 514,580$ for each 
calendar year through 1989. 22 The sum which is paid to the town will be determined by increasing or reducing the sum $(\$ 514,580)$ by the same percentage as the basic annual rental payment by E.B. ${ }^{23}$ This calculation also applies to other firms under lease at Quonset-Davisvil1e. The assessed value of other facilities that are covered by leases and having terms of one year or less sha11 be determined by multiplying the rental received by the Port Authority by 15 percent. Facilities that will not be covered by an agreement to lease shall reflect the town tax rate of the assessed value of each facility. 24

This agreement also has a three year transition period in which the town will be able to phase in the services. The transition began January 1, 1980, at which time the Port Authority reduced its road maintenance and police protection at the site. During the transition period, there will be an adjustment of the gross amount of tax payments paid to the town by the Authority. The breakdown of the adjustment period is as follows: 25

$\begin{array}{cc}\text { Calendar Year } & \text { Percentage of Gross Amount } \\ 1980 & 50 \% \\ 1981 & 662 / 3 \% \\ 1982 & 831 / 3 \% \\ 1983 & 100 \%\end{array}$

This breakdown reflects the amount of services the town is responsible to provide over the three years. For instance, in 1983 the town will be required to provide all the police and fire protection, as we11 as a11 highway maintenance, subsequent1y, 
it will be paid 100 percent of the payments outlined in the agreement.

The Port Authority is responsible for delivering the tax payments to the town on a quarterly basis regardless of any failure of its tenants to meet their rents. The two parties also agreed to have "a harmonious working relationship, characterized by open and candid communications to develop a firstclass industrial and commercial park at Quonset-Davisvi11e."26

\section{Impact Evaluation Methodology}

Determining the number of future municipal employees needed in North Kingstown due to the projected population growth from Quonset-Davisville requires two steps: examining present levels of municipal employment and estimating the approximate proportion of the total workforce that will reside in North Kingstown. The number of municipal employees can be derived by conducting an inventory of the town workforce in 1980. Calculating the second figure is a relatively complicated procedure and will require three processes. First, data from previous Quonset-Davisville studies and regional household-size statistics will be used to calculate a resident proportion. Second, this proportion will be applied to the three development alternatives. Third, public manpower needs will be projected by the Service Standard Method. 27

\section{Additional Households and Residents}

In 1977 , a study of the socio-economic impacts of the Quonset-Davisville alternatives was undertaken by the Gladstone 
Associates, Inc. One of the areas the study focused on was the percentage of employees that would reside in North Kingstown over 25 years. Their methodology consisted of surveying the firms located at the site, such as Electric Boat, to determine how many employees moved into North Kingstown as a result of their jobs. The study showed that between 25 percent and 30 percent of the employees at the industrial site moved to North Kingstown over a five-year period. ${ }^{28}$ The firms that were surveyed may not be the same type which actually locate at the site in the future. However, the detailed statistical data concerning the characteristics of prospective firms and the market conditions of those firms does indicate that a moderate proportion of the projected employees will at least have the means to buy and rent housing units in North Kingstown. The largest percentage (34 percent) of employees is expected to be part of the professional and technical occupations (see table 20). Whereas the smallest proportion of employment is to be service workers ( 2 percent) and laborers ( 3 percent). Assuming that the skilled and professional employees make a moderate-to-high income, and that they desire to live close to their jobs, it is reasonable to expect that 25 percent-30 percent of the total future Quonset-Davisville workforce will reside in North Kingstown.

This breakdown of employees by occupation allows a detailed comparison between the scenarios. Since the alternatives differ only slightly, an average of the highest number of employees $(3,536)$ and the lowest $(2,755)$ will be used for this analysis $(3,146)$. With the average now calculated, the total number of 
TABLE 20

NUMBER OF EMPLOYEES EXPECTED TO RESIDE IN NORTH KINGSTOWN YEAR 25

\begin{tabular}{|c|c|c|c|c|c|}
\hline & & $\begin{array}{l}\text { Percent } \\
\text { of }\end{array}$ & I & $\begin{array}{l}\text { Scenario } \\
\text { II }\end{array}$ & I I I \\
\hline Occupation & & Tota $1 *$ & $25 \%-30 \%$ & $25 \%-30 \%$ & $25 \%-30 \%$ \\
\hline $\begin{array}{l}\text { Professiona1, Technic } \\
\text { Manageria1, Adminis }\end{array}$ & & & & & \\
\hline trative and Sales & $\ldots$ & $34 \%$ & $964-1,153$ & $1,000-1,119$ & $990-1,118$ \\
\hline Clerical and Kindred & $\ldots$ & $16 \%$ & $423-508$ & $451-541$ & $446-559$ \\
\hline Craftsmen, Foremen & $\ldots$ & $15 \%$ & $429-514$ & $461-554$ & $437-524$ \\
\hline Operatives, Transport & ... & $30 \%$ & $749-899$ & $853-1,023$ & $847-1,048$ \\
\hline Service Workers & ... & $2 \%$ & $54-64$ & $58-69$ & $58-70$ \\
\hline Laborers & $\ldots$ & $3 \%$ & $140-167$ & $124-149$ & $87-105$ \\
\hline Tota 1: & & $100 \%$ & $2,755-3,306$ & $2,946-3,536$ & $2,912-3,494$ \\
\hline
\end{tabular}

NOTE: Table derived by multiplying the projected total number of employees per occupational category by 25 percent and 30 percent. The numbers in each of the categories, above, are the number of employees expected to reside in North Kingstown by year 25 .

*The percentage of total is similar for each scenario.

SOURCE: Socio-Economic Assessment Alternatives of Reuse of Quonset-Davisville, Gladstone Associates, 1977. Appendix C. 
new North Kingstown residents due to the industrial development at Quonset-Davisville can be derived by analyzing household size associated with various types of residential developments. Statistics indicate that different types of housing have different proportions of household size. ${ }^{29}$

$\begin{array}{lc}\text { Types of Dwelling Units } & \text { Total Household Size } \\ \text { Single Family } & 3.931 \\ \text { Townhouse } & 2.200 \\ \text { Apartment } & 2.114\end{array}$

These household size figures are based on 1975 data compiled for the Northeast region of the United States. 30 The key to the projection of new residents lies in determining the mix of these types of dwelling units that will be constructed in North Kingstown over 25 years.

A number of factors will influence the type and number of housing units that will be built in the future. These factors include the following:

- National economic condition.

- Legal constraints to development such as zoning and subdivision regulation.

- Nationa1 and regional energy situation.

- Physical constraints to development such as unsuitable 1 and.

- Trends in family size.

To account for these ever-changing variables, various 1 and use development alternatives and types of housing development will be considered. Although the following three development 
alternatives may not actually take place, they do enable the reader to better evaluate the variations in population increases (see table 21).

Alternative 1 , which assumes that 100 percent of the new housing units constructed in North Kingstown will be single family, has the highest population estimate of 12,367 . A1ternative 3 , on the other hand, indicates that by increasing the number of townhouse units and decreasing the number of single family units, there will be significantly less of a population increase than the other two alternatives. Alternative 2, which is similar to the current housing mix in North Kingstown, suggests that there be a diversification with a strong emphasis on single-family development.

The reasoning behind using a constant number of housing units for each alternative is based on the assumption that the Town of North Kingstown will not create different lot sizes for different types of residential development. That is, single family, townhouse, and apartment units, will all have the same minimum lot sizes depending on the zone. However, this is not to say that the zoning ordinance will not be revised occasionally to encourage more dense developments than normally required. If preferential treatment is given to one of the three types of residential developments discussed in this analysis, then a much different total number of housing units will result. Nevertheless, it is beyond the power of this analysis to compensate, with any accuracy, the future zoning ordinance changes in North Kingstown. Thus, the current zoning regulations standards will be used for this model. 
TABLE 21

NUMBER OF NEW HOUSING UNITS AND ADDITIONAL RESIDENTS EXPECTED IN NORTH KINGSTOWN AS A RESULT OF

Q/D DEVELOPMENT

$\begin{array}{lccc}\text { ALTERNATIVE \#1 } & \begin{array}{c}\text { Housing } \\ \text { Units }\end{array} & \begin{array}{c}\text { Persons Per } \\ \text { Household }\end{array} & \begin{array}{c}\text { Number of } \\ \text { Residents }\end{array} \\ 100 \% \text { Single Family } & 3,146 & 3.931 & 12,367\end{array}$

ALTERNATIVE \# 2

\begin{tabular}{lrrr}
$70 \%$ Sing1e Family & 2,202 & 3.931 & 8,656 \\
$20 \%$ Townhouses & 629 & 2.200 & 1,384 \\
$10 \%$ Apartments & 315 & 2.114 & -666 \\
\hline & 3,146 & & 10,706
\end{tabular}

ALTERNATIVE \# 3

$\begin{array}{lrrr}50 \% \text { Single Family } & 1,573 & 3.931 & 6,184 \\ 40 \% \text { Townhouses } & 1,258 & 2.200 & 2,768 \\ 10 \% \text { Apartments } & -315 & 2.114 & -666 \\ & 3,146 & & 9,618\end{array}$

1 This is an average of the number of employees expected to reside in North Kingstown over the 25 year study period.

2 Northeast averages. The Fiscal Impact Handbook, p. 34 . 
Future Public Service Employment Needs

With the population projected for each alternative, it is possible to calculate future public service needs. One technique typically employed to project manpower needs is the "Service Standard Method." 31 This methodology can provide a detailed estimate of employment by service category for moderately growing suburbs and cities which are contemplating a particular population increase. These general estimates of municipal function service levels are based on ratios per 1,000 population for different size municipalities. In addition, the ratios are calculated by regions of the United States, and this analysis will use ratios for the northeast region. In general, this technique determines the number of additional employees that will be required to maintain current levels of municipal service functions as a result of growth (see table 22).

Thus, Column 1 indicates the current number of ful1-time employees in each of the municipal functions. For instance, it takes 15 full-time employees to provide accounting, assessment, and finance services for the 1980 town population of 21,615 . Column 2 of Table 22 recommends that for every 1,000 additiona 1 residents a particular manpower ratio should be used in order to maintain current municipal service levels. These ratios are based on a population increase of between 10,000-24,999.32 Although only two of the three alternatives fall within this range, the third alternative is close enough to the lower end of the range, and for comparison purposes, the same manpower ratio will be used. 
TABLE 22

CURRENT AND PROJECTED EMPLOYMENT FOR THREE DEVELOPMENT ALTERNATIVES

Current

Employment

(1)

Number of

Full-time

Town

Employees 1980

Municipal
Functions

$\begin{array}{r}15 \\ 19 \\ 46 \\ 50 \\ 10 \\ 8 \\ 6 \\ \hline\end{array}$

Finance $^{1}$

Administration ${ }^{2}$

Police

Fire

Water Supply

Recreation ${ }^{3}$

Library

Totals

Man-power

Ratio per

1,000

Population

Alternative \#1 12,367

(3)

(4)

Increase

Total
$(1)+(3)$

Projected Increase in Employment

Alternative \#2 10,706

(5) (6)

(6) (7)

(8)

Increase

Total
$(1)+(5)$

Increase

Total

$(1)+(7)$

Alternative \#3 9,618

$(1)+(5)$

$\begin{array}{rrr}.45 & 6 & 21 \\ .61 & 8 & 27 \\ 2.08 & 26 & 72 \\ .99 & 12 & 72 \\ .40 & 5 & 15 \\ .34 & 4 & 12 \\ .26 & 3 & 9 \\ & 64 & 228\end{array}$

22

$\begin{array}{rrrrr}5 & 20 & 4 & 19 \\ 6 & 25 & 6 & 25 & \\ 22 & 68 & 20 & 66 & \\ 11 & 71 & 10 & 70 & 0 \\ 4 & 14 & 4 & 14 & \\ 4 & 12 & 3 & 11 & 8 \\ 3 & 2 & 2 & -213\end{array}$

Column (1)-Source: North Kingstown Finance Department, 1980.

Column (2)-Source: Burchell \& Listokin, Fiscal Impact Handbook. p. 73. Based on population increases of 10,00024,999 in northeast region of the United States.

Column (3), (5), (7) - The increases are derived bu multiplying the municipal function ratio by the alternative population projection.

Notes:

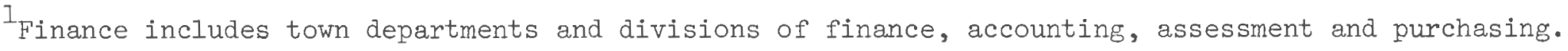

2 Administration includes town manager, town clerk, and planning.

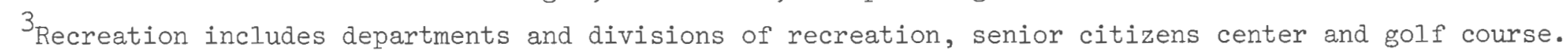


To arrive at the employment increase for each of the three alternatives, it is necessary to multiply the particular municipal function manpower ratio in Column 2 by the number of thousands of population increase in each alternative. In Alternative 1, there is a projected population increase of 12,367. When this increase is multiplied, for example, by the finance function manpower ratio of .45 , the indication is that there will be a need for six additional employees over 25 years. Six employees are recommended so that the finance function will be maintained at its current service level. The number of additional employees does not vary significantly among the alternatives; but as expected, the larger the population increase, the more employees will be needed in the municipal service functions. The reason for not including school system employment in this chart is that those figures are based on the number of school children. That particular calculation will be discussed in the school section of this chapter.

It must be pointed out that these regional employment standards are only guides for estimating future employment needs. The actual employment need will depend on town goals and priorities, automation and computerization, and the types of services provided by the municipality. The projections are, however, good indicators for the amount of office or work space, equipment, and other capital costs that would be needed with an increasing number of municipal employees. As indicated in Table 23, the town may want to consider opting for a diversified residential housing stock to minimize the impacts of providing additional services. 
Impacts on Target Area Schools

School service needs are based on the number of students rather than on the total population. Thus, the projected student increases, which are found in Appendix E, will provide the basis of this particular analysis. To estimate the number of additional school employees that are needed as a result of the student increases in each tract, a northeast regional standard of 86 ful1-time employees for every 1,000 students will be used. The number of school children and additional employees have been compiled in a matrix (see table 23). The various development options and housing alternatives are shown so that a broad analysis of the impacts can be discussed. For instance, in Census Tract 501.01, if only single family homes are built on all the potential house lots, there would be a student population increase of 1,559 , which would require 134 additional full-time school employees. On the other end of the spectrum, if on 1 y 50 percent of the potential housing lots were developed in a mixed use fashion (50 percent single family, 40 percent townhouses, 10 percent apartments), there would be a need for 42 additional employees to service 490 new students. Statistics for both census tracts indicate that different types of housing development create different proportions of school children, which subsequently affects the school employment need. Consequently, minimizing the proportion of single family homes developed will also decrease the need for additional school employees.

To determine whether new schools will be needed to facilitate the projected school children increase in the two census tract 
TABLE 23

PROJECTED SCHOOL SYSTEM MAN-POWER INCREASES DUE TO

QUONSET-DAVISVILLE REDEVETOPMENT OVER 25 YEARS

Census Tract 501.01

\begin{tabular}{ll} 
100\% Development Option \\
\hline $\begin{array}{l}\text { Additional } \\
\text { Students }\end{array}$ & $\begin{array}{l}\text { Aditional } \\
\text { School } \\
\text { Employees }\end{array}$
\end{tabular}

Alternative \#1

Alternative \#2

Alternative \#3

Census Tract 501.02

\section{0\% Development Option \\ Additional Students}

Alternative \#1

Alternative \#3

$\begin{array}{ll}985 & 85 \\ 760 & 65 \\ 618 & 53\end{array}$

Alternative \#2

$$
\begin{array}{r}
1,559 \\
1,202 \\
978
\end{array}
$$

134
103
84

84

\begin{tabular}{ll} 
75\% Development & Option \\
\hline Additional & Additional \\
Students & $\begin{array}{l}\text { School } \\
\text { Employees }\end{array}$
\end{tabular}

1,168

902

734

$\begin{array}{ll}\text { 75\% Development } & \text { Option } \\ \text { Additional } & \begin{array}{l}\text { Additional } \\ \text { School } \\ \text { Students }\end{array}\end{array}$

50\% Development Option

$\begin{array}{ll}\text { Additional } & \text { Additional } \\ \text { Students } & \text { School } \\ & \text { Employees }\end{array}$

779

600

67

78

63

\section{0\% Development Option}

$\begin{array}{ll}\text { Additional } & \text { Additional } \\ \text { Students } & \text { School } \\ & \text { Employees }\end{array}$

739
571
465

64
49
40

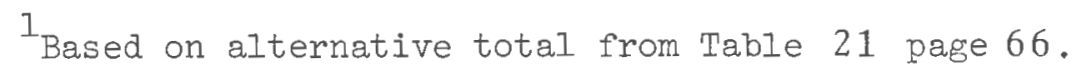

${ }^{2}$ Based on a northeast regional rate of 86 full-time school employees per increase of 1,000 students.

Alternative \#1: $100 \%$ single family housing.

Alternative \#2: 70\% single family housing, 20\% townhouses, 10\% apartments.

Alternative $\# 3$ : 50\% single family housing, 40\% townhouses, $10 \%$ apartments. 
areas, it was necessary to inventory the number of schools as well as locate the schools and their district boundaries on a map. In the northern tract are located three of the town's five functioning elementary schools and one of the middle schools (see map 13). Each elementary school in Tract 501.01 has a particular neighborhood district, while the middle school services other areas of the town, including Tract 501.02. The on 1y school within Tract 501.02 , besides the two non-functioning schools (Hoskins and Quonset), is the Stony Lane Elementary School.

The inventory of the schools in the census tracts shows the student capacity and the 1980 student enrollment (see table 24). In the northern tract, both the middle and elementary schools have a substantial leeway before reaching maximum capacity. Both systems are operating at approximately 55 percent of capacity. The elementary school in the southern tract, however, is nearly ful1. It is at 82 percent of its maximum capacity.

For a precise account of the school system impacts, it will be necessary to disaggregate the number of projected school children by their grade leve1. As of October, 1980, the high school held 1,850 students or 31 percent of North Kingstown's total student population; the middle school held 1,072 students (21 percent); and the elementary school held 2,100 students (42 percent). However, 610 of the high school students were from towns which do not have public high schools. Hence the actual town student population breakdown is 28 percent high school, 24 percent middle school, and 48 percent elementary 


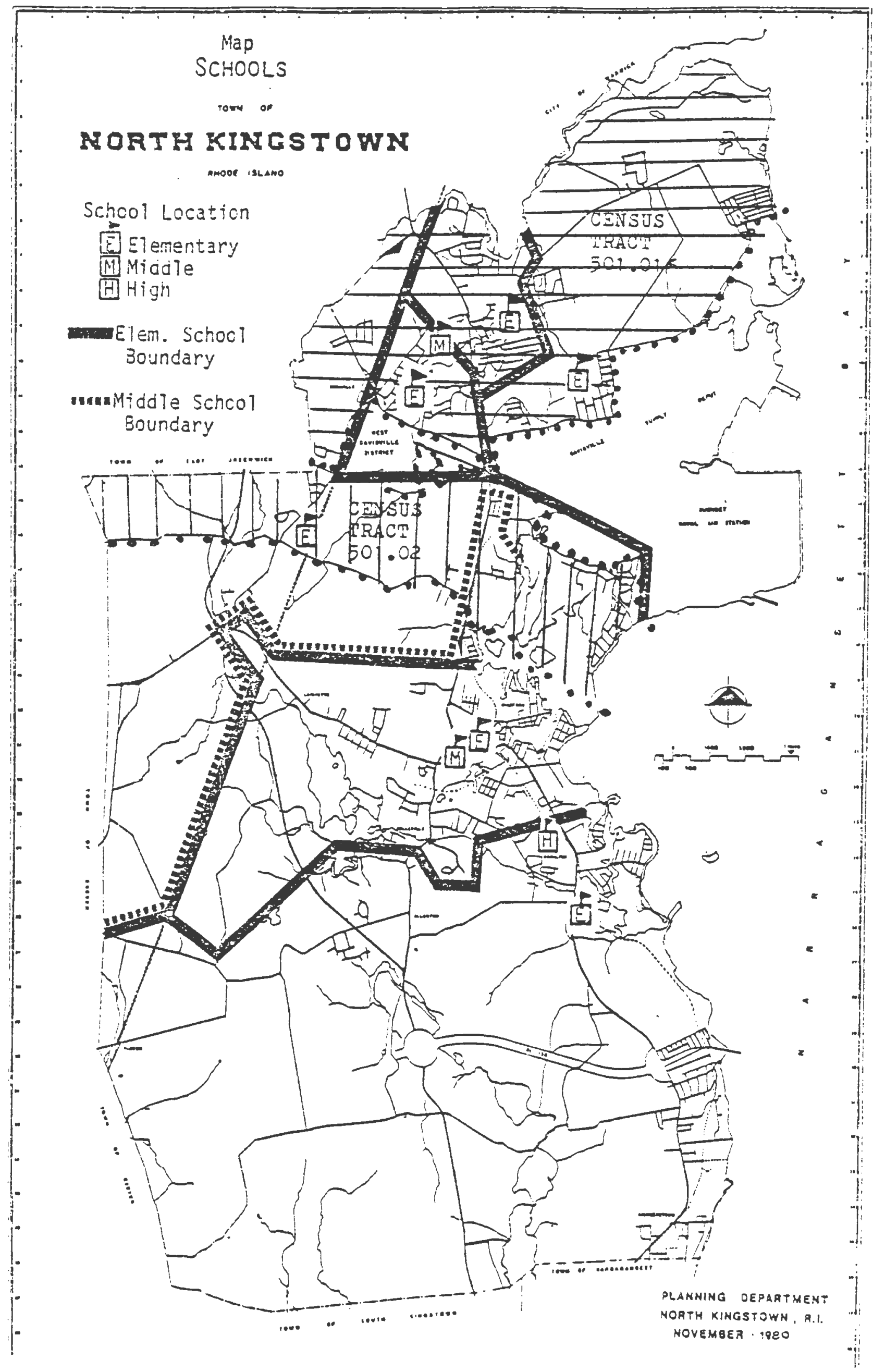


TABLE 24

INVENTORY OF SCHOOL FACILITIES

Census Tract 501.01

\begin{tabular}{|c|c|c|c|}
\hline & $\begin{array}{l}\text { Maximum } \\
\text { Capacity }\end{array}$ & $\begin{array}{c}\text { October } 1980 \\
\text { Enrol1ment }\end{array}$ & Acreage \\
\hline Davisville Middle School & $1,000-1,075$ & 589 & 21 \\
\hline Davisville Elementary School & $400-540$ & 264 & 11 \\
\hline Forest Park Elementary School & $450-500$ & 296 & 10 \\
\hline Quidnessett Elementary School & $425-475$ & 294 & 26 \\
\hline
\end{tabular}

Census Tract 501.02

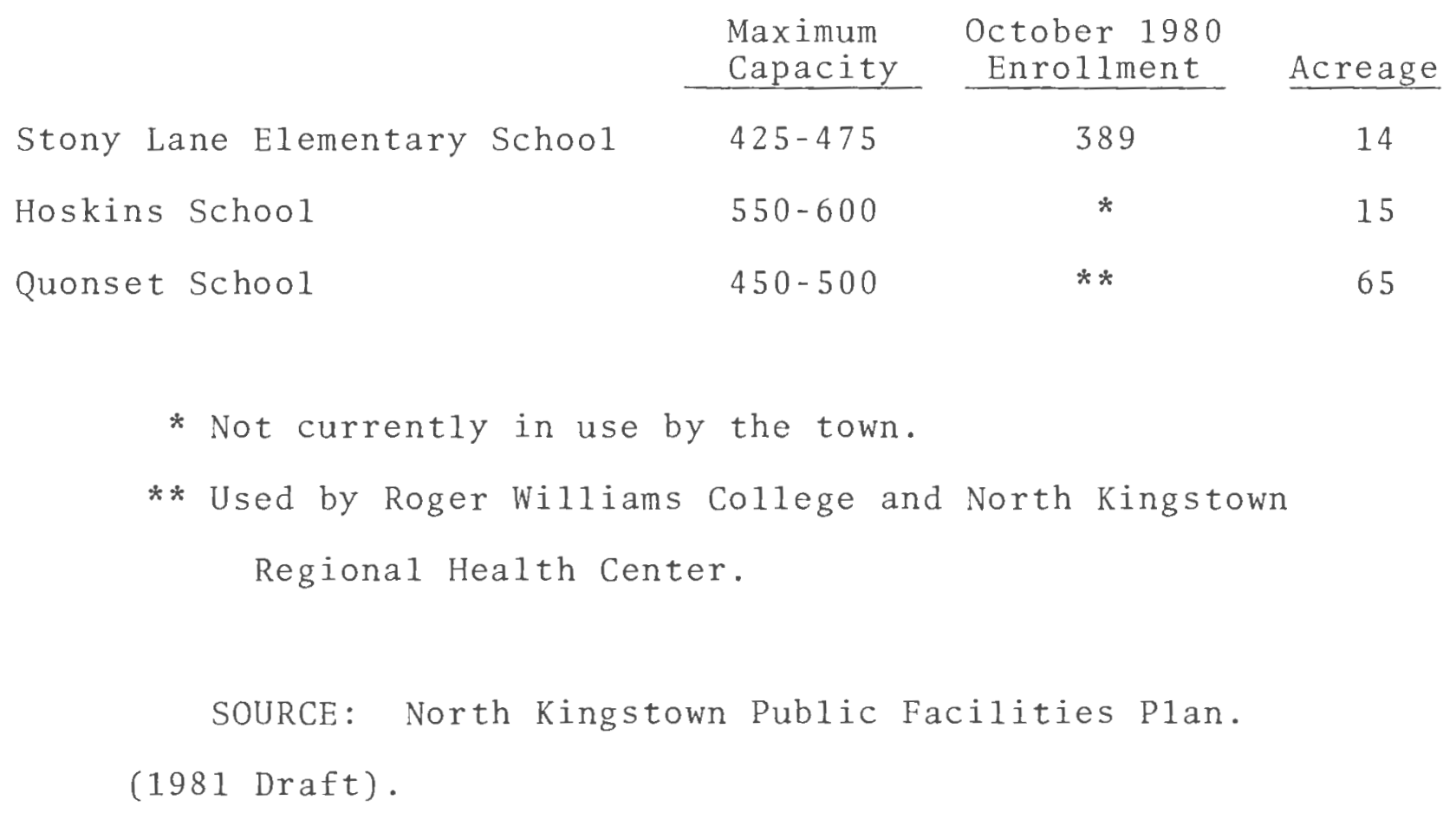


TABLE 25

DISTRIBUTION OF SCHOOL_AGE CHILDREN

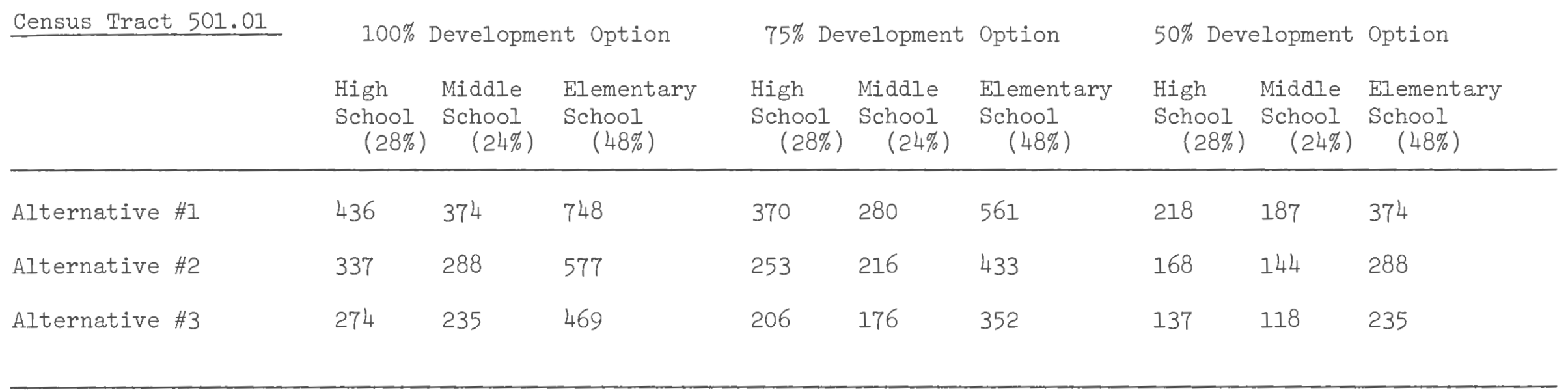

75\% Development Option

$\begin{array}{lrcrrr}\text { High } & \text { Middle } & \text { Elementary } & \text { High } & \text { Middle } & \text { Elementary } \\ \text { School } & \text { School } & \text { School } & \text { School } & \text { School } & \text { School } \\ (28 \%) & (24 \%) & (48 \%) & (28 \%) & (24 \%) & (48 \%)\end{array}$

$\begin{array}{lccccccccc} & & & (28 \%) & (24 \%) & (48 \%) & (28 \%) & (24 \%) & (48 \% \\ \text { Alternative \#1 } & 276 & 236 & 473 & 207 & 177 & 355 & 138 & 118 & 236 \\ \text { Alternative \#2 } & 365 & 182 & 365 & 160 & 137 & 274 & 106 & 90 & 181 \\ \text { Alternative \#3 } & 173 & 148 & 297 & 130 & 112 & 223 & 86 & 74 & 148\end{array}$

50\% Development Option

High Midale Elementary

School School School $\begin{array}{lll}(28 \%) & (24 \%) & (48 \%)\end{array}$

Note: The numbers in parenthesis represent current distribution of North Kingstown students. Breakdown of the number of school children is based on the total number of school children projected for each Census Tract, 
school. Applying these proportions to the projected school enrollment due to Quonset-Davisville development will enable a comparison with the school capacities.

The variation in the number of school children is rather significant between the various housing alternatives and development options (see table 25). On one end of the spectrum, there would be 748 additional elementary school children in Census Tract 501.01 , assuming that 100 percent of the house lots are developed as single family homes. However, if only 50 percent of the land is built upon with a proportion of 50 percent single family, 40 percent townhouses, and 10 percent apartments, there would only be 235 elementary school children. Even though the northern tract has the capacity to hold approximately 661 more students, there is one option/alternative that could cause overcrowding at the elementary level. Alternative one at the 100 percent development option would create an over capacity by 87 students $(748-661=87)$. Nevertheless, comparisons of current school capacities and projected student increases indicate that few if any schools will reach capacity in Tract 501.01 .

In the southern tract, however, it is a very different situation. There are only 87 seats available in the elementary school before maximum capacity is reached. According to Table 25 , every alternative and option would result in this capacity being exceeded. In fact, under the 100 percent option for alternative one, there would be a need for 387 seats $(473-86=387)$. Even if only 50 percent of the house lots are developed, there would be an overcrowding by 62 students. 
Since there is no middle school in the southern tract, it will be necessary to combine the increases for both tracts to estimate the impact. There is room for an additional 486 middle school students; however, the combined projected middle school population reaches as high as 610 students under alternative one and the 100 percent development option. Nevertheless, the other combined increases do not cause the middle school to reach capacity. In addition to the middle school effects, the high school has room for approximately 700 additional students. Although only one combined alternative/option estimate surpasses this capacity, any policy decision concerning the expansion of the high school has to be made in perspective of town-wide growth and not just the growth in two census tracts.

A MUNIES study, done in 1977, addressed the educationa1 public facility needs of North Kingstown. 33 The study recommended that for increased elementary school capacity the school department should first re-open the Hoskins Elementary School, second re-open the Quonset Elementary School, and finally build new schools if necessary. The MUNIES report also goes on to say that if student populations increased above the capacities of the middle and high schools, that new school construction would be the best a1ternative.

Before any action is taken on the MUNIES recommendations, policymakers of North Kingstown have to determine the natural school population increase, in addition to the induced QuonsetDavisville population growth. Also, the location of these new residents will play a major role in deciding how to accommodate 
a larger school population. Rather than constructing new schools, it might be feasible to expand present facilities or renovate older structures. Also, redistricting present school districts would better disperse students to lesscrowded schools throughout the town.

Municipal Costs and Revenues of Residential Development

In addition to impacting the school system, the mix of future housing plays a prominent role in the financial base of a community. Average annual municipal costs and revenues have been compiled for these types of residential housing units in the northeast region of the United States (see table 26). For instance, an $\$ 80,000$ single family house of four persons with 1.6 children creates a deficit to the municipality of $\$ 1,170$ per year. This cost to the town is mainly due to the high price of education, since it cost approximately $\$ 2,350$ per year to educate 1.6 children. On the other hand, a $\$ 45,000$ townhouse with a household size of 2.6 and .4 school children, although providing less revenues per year to the municipality, actually has a net plus of $\$ 35$ after al1 the costs are deducted. Garden apartments are even better revenue producers, with an average benefit to the municipality of $\$ 70$ per year.

When these economic standards for different types of residential development are applied to the expected number of housing units due to Quonset-Davisville development, it is possible to realize just how much mixing housing types matters (see tab1e 27). If this northern portion of North Kingstown (Tract 501.01) is developed to its fullest (100 percent) and the 
TABLE 26

MUNICIPAL COSTS OF RESIDENTIAL DEVELOPMENT

Example of Municipal Costs and Revenues (Annua11y)

Single Family Single Family Garden

Detached (1) Attached (2) Apartments (3)

Estimated Revenues
Per Unit
$\$ 1,470$
$\$ 825$
$\$ 550$

Estimated Costs

Schools

$\$ 2,350$

$\$ 600$

$\$ 300$

Genera1 Fund

$\$ 290$

$\$ 190$

$\$ 180$

Total:

2,640

790

480

Net Balance:

$-1,170$

$+35$

$+70$

1) Assumes a $\$ 80,000$ home, 4 bedrooms on 1 acre of 1 and with 1.6 school children, household size 4.0 .

2) Assumes a $\$ 45,000$ unit, 2 bedrooms, .4 school children with 2.6 persons per household.

3) Assumes rent $\$ 250.00$ for 1 bedroom, .2 school children, household size 2.5 .

SOURCE: Gladstone Associates, p. 60.

alternative chosen by the community is all single family homes, it is likely that there could be an annual deficit to the town of $\$ 1,500,000$. This burden to taxpayers can, however, be reduced to half of what is expected in Alternative \#1 by simply allowing, through zoning and other ordinances, a diversification of housing types in the future. Since North Kingstown's housing mix most 
closely resembles Alternative \#2, it is 1ike1y that future housing development will follow those proportions. That being the case, it would hold that the town can expect to pay between $\$ 1,034,95$ - \$517,505 in increased costs for additiona 1 housing in Tract 501.01 and between $\$ 754,355-\$ 326,575$ in Tract 501.02 .

These costs cannot be expected to be reached immediately since the housing development scenarios are supposed to spread housing construction over a 25 -year period. It must also be pointed out that many of the variables which make up the cost standards could, and probably will, change over that period of time. Hence, the figures in Tables 27 and 28 should be viewed as indicators of what the costs and impacts are for current housing types. Aside from the monetary benefits, it seems incumbent upon a community, because of the sky-rocketing constructing costs and increasing desire of many people for alternative housing styles, to allow for a diverse housing market. 
TABLE 27

COSTS OF QUONSET-DAVISVILLE RELATED RESIDENTIAL DEVELOPMENT

CENSUS TRACT 501.01

\begin{tabular}{|c|c|c|c|c|c|c|c|}
\hline & Per Unit & $100 \%$ & $\begin{array}{l}\text { \% Development } \\
\text { Option }\end{array}$ & $75 \%$ & $\begin{array}{l}\text { Development } \\
\text { Option }\end{array}$ & & $\begin{array}{l}\text { Development } \\
\text { Option }\end{array}$ \\
\hline Alternative \#1 & $\begin{array}{l}\text { Cost }^{1} \text { or } \\
\text { Revenue to } \\
\text { Municipality }\end{array}$ & $\begin{array}{l}\text { Housing } \\
\text { Units }\end{array}$ & $\begin{array}{l}\text { Annual Sum } \\
\text { to North } \\
\text { Kingstown }\end{array}$ & $\begin{array}{l}\text { Housing } \\
\text { Units }\end{array}$ & $\begin{array}{l}\text { Annual Sum } \\
\text { to North } \\
\text { Kingstown }\end{array}$ & $\begin{array}{l}\text { Housing } \\
\text { Units }\end{array}$ & $\begin{array}{l}\text { Annual Sum } \\
\text { to North } \\
\text { Kingstown }\end{array}$ \\
\hline 100\% Single Family & - $\$ 1,170$ & 1,286 & $-\$ 1,504,620$ & 964 & $-\$ 1,127,880$ & 643 & - $\$ 752,310$ \\
\hline
\end{tabular}

\section{Alternative $\# 2$}

\begin{tabular}{|c|c|c|c|c|c|c|c|c|c|c|}
\hline 70\% Single Family & $-\$$ & 170 & 900 & $-\$ 1$ & 53,000 & 675 & $-\$$ & 789,750 & 450 & $-\$ 526,500$ \\
\hline $20 \%$ Townhouse & $+\$$ & 35 & 257 & $+\$$ & 8,995 & 193 & $+\$$ & 6,775 & 129 & $+\$ 4,515$ \\
\hline$\%$ Apartment & $+\$$ & 70 & $\frac{129}{1,286}$ & $\frac{+\$}{-\$ 1}$ & $\frac{9,030}{34,975}$ & $\frac{96}{964}$ & $\frac{+\$}{-\$}$ & $\frac{6,720}{776,275}$ & $\frac{64}{643}$ & $\begin{array}{r}+\$ 4,480 \\
-\$ 517,505\end{array}$ \\
\hline
\end{tabular}

Alternative \#3

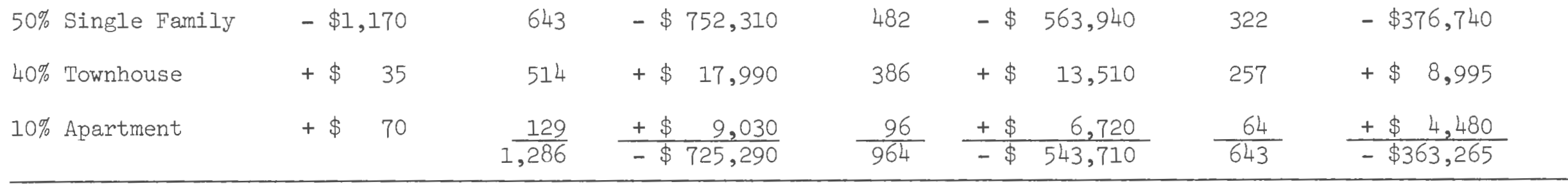

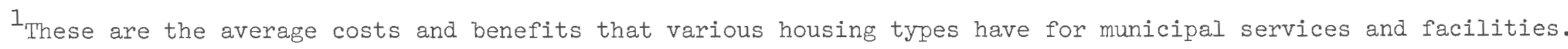
Gladstone Associates, p.60. 
TABLE 28

COSTS OF QUONSET-DAVISVILLE RELATED RESIDENTIAL DEVELOPMENT

CENSUS TRACT 501.02

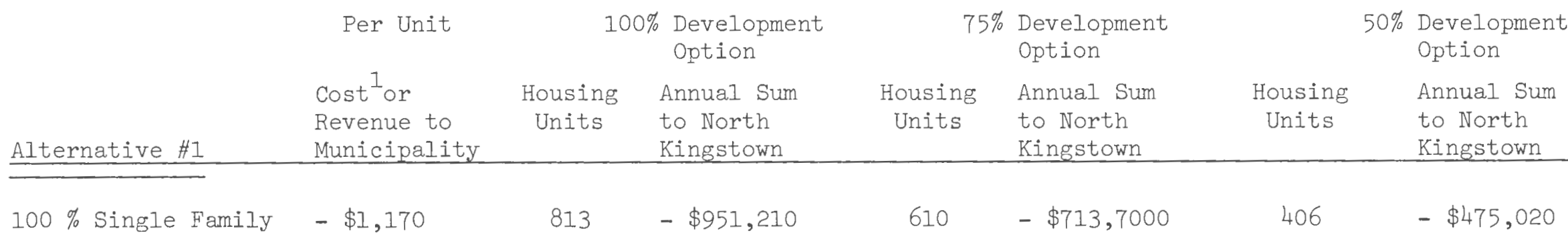

\section{Alternative $\# 2$}

$\begin{array}{lccccccc}70 \% \text { Single Family } & -\$ 1,170 & 569 & -\$ 665,730 & 427 & -\$ 499,590 & 284 & -\$ 322,280 \\ 20 \% \text { Townhouse } & +\$ & 35 & 163 & +\$ 5,705 & 122 & +\$ 4,270 & 81 \\ & +\$ & 70 & \frac{81}{813} & \frac{+\$ 5,670}{-\$ 654,355} & \frac{61}{610}+\frac{+\$ 4,270}{-\$ 491,050} & \frac{41}{406} & \frac{+\$ 2,835}{-\$ 326,575}\end{array}$

Alternative \#3

$\begin{array}{llccccccc}50 \% \text { Single Family } & -\$ 1,170 & 406 & -\$ 475,020 & 305 & -\$ 356,850 & 203 & -\$ 237,510 \\ 40 \% \text { Townhouse } & +\$ & 35 & 325 & +\$ 11,375 & 244 & +\$ 8,540 & 162 & +\$ \quad 5,670 \\ 10 \% \text { Apartment } & +\$ & 70 & \frac{81}{813} & \frac{+\$ 5,670}{-\$ 457,975} & \frac{61}{610}+\frac{+\$ 4,270}{-\$ 344,040} & \frac{41}{406} & \frac{+\$ 2,870}{-\$ 228,970}\end{array}$

$I_{\text {Th }}$ are the average costs and benefits that various housing types have for municipal services and facilities. Gladstone Associates, p.60. 
CONCLUSION

The results of this study indicate that QuonsetDavisville redevelopment has the potential of significantly impacting the target area and the entire Town of North Kingstown. Analysis of the state's three development scenarios showed that each scenario will create a substantial number of new jobs $(11,500)$ over 25 years. Approximately 30 percent of these employees are estimated to reside within the town which is expected to markedly increase population, especially in the target area.

A problem arises, however, as to who will pay for these additional municipal services. The obvious solution is to increase the residents' property taxes. But if the 1981 town budget meeting is a reflection of the future, there should be serious concern over the possible decline in services. At that meeting, the general budget was slashed by $\$ 225,000$. This is going to result in employee lay-offs with a subsequent decrease in services. Many residents see the payments in lieu of taxes received for providing services to the Quonset-Davisville site as being a windfall of profits. But, even though the payments will likely cover the direct costs to the town for its services, the indirect costs of providing services to potential new residents from QuonsetDavisville will dissolve any expected gain. 
Land use decisions are the major factors in North Kingstown's future economic condition. Statistics have been presented which showed that different types of residential development produces different proportions of household; the denser the residential development, the smaller the household size tends to be. Thus, town land use policies must provide for a diversified residential housing market to minimize the indirect impacts from Quonset-Davisville.

Calculations have indicated that the growth expected in North Kingstown due to the site redevelopment could in part be accommodated within the target area (Census Tracts 501.01 and 501.02). A significant proportion of this growth, however, will likely spill over to the remainder of the town. An analysis of the other town census tracts would be necessary to determine the total amount of developable land in North Kingstown. Rational policies could then be formed which would incorporate both physical as well as social concerns. Growth guiding techniques, such as phased growth, capital improvement programming, public facilities planning can be used, along with revised zoning and subdivision regulations, to implement the 1 and use policies.

Even though the Town of North Kingstown is expected to be indirectly impacted by the employees of Quonset-Davisville, the town is likely to fair better than many of the surrounding communities. North Kingstown is at least receiving compensation for providing some of the services to the site, whereas other neighboring municipalities will have to absorb a large proportion of employees without compensation. 
Towns such as Richmond, Exeter, and Charlestown located to the west of North Kingstown are likely to encounter substantial development pressure, especially from the higher income employees of Quonset-Davisville who will be able to afford new single family homes. These sparsely populated Rhode Island communities contain abundant amounts of open space; and since these towns have only limited growth control mechanisms (two or more acre lot requirements), there is likely to be extensive development sprawl with poor use of the 1and. In addition, these towns will then be required to provide costly services for the additional, probably, single fami1y homes.

There will also be impacts on communities such as Warwick and Cranston which have large supplies of rental units. The major threat to these communities is a possible influx of renter-oriented Quonset-Davisville employees. These potential renters could displace elder $1 y$, low income family, and young adult tenants by creating a demand for rental units which forces the rents to skyrocket. Provisions could be made to minimize this dislocation factor by monitoring rents and vacancy levels to determine when shortages are about to occur. The only way to prepare for these impacts, however, is by becoming aware of a potential problem.

Unfortunately, the state of Rhode Island is much more concerned with converting the Quonset-Davisville into a major industrial complex then it is about warning communities of potential impacts from that redevelopment site. The state has 
a capable regional planning agency at its disposal which could be used to evaluate these state-wide impacts. The research findings from the regional studies could then be passed along to the municipalities so that they can plan to meet predicted growth.

There is very little doubt that North Kingstown and its surrounding region is on the verge of encountering a second economic boom. This is especially apparent considering the current national political climate, which is encouraging industrialization and economic growth. The threat of a bust, however, is not as great in comparison to the Navy related boom-bust cycle at Quonset-Davisville. The difference this time is that the industrial-commercial mix at QuonsetDavisville will be diverse enough so that if one or two firms move or fold under, the economic base of the town will only feel tremors from such a loss. 
FOOTNOTES

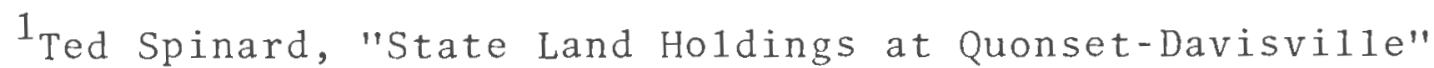
(Memo to the Economic Development Corporation, Providence, R.I., Apri1 12, 1981).

${ }^{2}$ Rhode Island Statewide Planning Program, Technical Paper Number 83, Rhode Island Population Projections by County, City and Town. (Providence, R.I.: Statewide Planning Program, Apri1 1979).

${ }^{3}$ Coastal Resources Center, Marine Technical Report \#55, The Redevelopment of Quonset-Davisvil1e: An Environmenta1 Assessment (Kingston, R.I.: University of Rhode Island, 1977), p. 67 .

4 Ibid.

${ }^{5}$ Ibid., p. 68.

${ }^{6}$ Ibid., p. 70 .

${ }^{7}$ Ibid., p. 70 .

${ }^{8}$ Rhode Island Statewide Planning Program, Rhode Island Population Projections.

${ }^{9}$ Joseph D. Lombardo, The Economic Impacts of Navy Cutbacks (Rhode Island: Department of Economic Development, May 18, $1977)$, p. 3 .

${ }^{10}$ Ibid. , p. 4

${ }^{11}$ Keyes Associates, Report to the Rhode Island Department of Economic Devevelopment, Quonset Point Technical Park:

Facilities Study (Providence, R.I.: Keyes Associates, March 1977), p. 40 .

${ }^{12}$ Ted Spinard. "State Land Holdings."

13 North Kingstown Planning and Development Department, "North Kingstown Community Guide Plan Land Use Element," North Kingstown, 1981. (Draft.)

${ }^{14}$ North Kingstown Planning and Development Department, "Community Guide Plan: Element 4 Public Facilities Plan." North Kingstown, 1981, p. 23. (Draft.) 


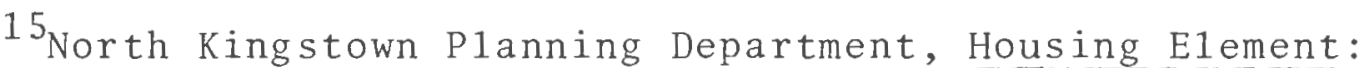
1979 Update (North Kingstown, R. I. : Planning Department, Ju1y $\overline{1979), ~ p . ~} 4$.

16

Gladstone Associates and Stah1/Bennett Inc., Rhode Island Military Housing Study: Fina1 Report (Rhode IsIand: Gladstone Associates, November 1975), p. 12.

17

Economic Development Corporation, Quonset-Davisvil1e Agreement between North Kingstown and Rhode Island Port

Authority and Economic Development Corporation (Rhode Is land: Economic Development Corporation, April 28, 1980), p. 1.

18

North Kingstown Planning Department, Servicing QuonsetDavisville, Report to the Town Council, Nor th Kingstown, R.I. , 1978 (North Kingstown, R. I.: Planning Department, 1978), p. 1.

19 Ibid., p. 3.

20

Economic Development Corporation, Quonset-Davisville Agreement, p. 3 .

21 Ibid., p. 4 .

22

Ibid.

23

Ibid.

24

Ibid., p. 5 .

25

Ibid.

26

Ibid., p. 7 .

27 Robert $W$. Burche11 and David Listoken, The Fiscal

Impact Handbook (New Brunswick, N.J.: Center for Urban Policy Research, 1980), p. 18.

${ }^{28}$ Gladstone Associates, Socio-Economic Assessment of the Reuse Alternatives of Quonset Point and Davisville, R.I. (Rhode Island: Department of Economic Development, August 1977), p. 43 .

29

Ibid., p. 35 .

30

Ibid.

31

Ibid., p. 40 .

32

Ibid., p. 42 .

33 Tischler, Marcou, and Associates, Inc., Fiscal Impact Study, North Kingstown, R.I., MUNIES Report (washington, D.C.: May 1978), p. 2. 


\section{APPENDIX A}

CIVILIAN POPULATION OF NORTH KINGSTOWN 
The preliminary 1980 census data has been utilized to determine the loss of military population in North Kingstown from 1974.

Militay Related Areas

\begin{tabular}{|c|c|c|}
\hline Census Tract & $\frac{\text { Military Population }}{\underline{1980}}$ & Assumtions \\
\hline 502.99 & 4,607 & 1. Loss of population in Tracts \\
\hline 502 & 4,686 & $\begin{array}{l}\text { directly related to military } \\
\text { withdrawal. }\end{array}$ \\
\hline 501.02 & $\frac{1,798}{11,091}$ & $\begin{array}{l}\text { 2. Military population off-base } \\
\text { undetermined. }\end{array}$ \\
\hline
\end{tabular}

1970 Total Town Population 29,793

Estimated Military Population $\quad-11,091$

1970 Civilian Population 18,702

1980 Total Town Population 21,615*

1970 Civilian Population $\quad-18,702$

Actual North Kingstown

2,913 - $16 \%$ increase $\mathbf{r}$ om 1970-1980

Civilion Population

Growth

*

1980 Preliminary Census Data, U.S. Bureau of the Census.

Source: Bureau of the Census, 1970 and 1980 Population in North Kingstown, R.I.. (see next page of this Appendix). 
TABLE 29

Housing Units

1980
Total Vacant Vacancy Local t970 Change
Rate Est. Fotal

North Kingstown Town Wickford (CDP)

Tract 501.01

ED 178

ED 179

ED 24IT

ED 2410

Tract 501.02

ED 184

ED 185

ED 186

ED 242

Tract 502

ED 180

ED 181

ED 182

ED 183

Tract $50 \dot{2} .99$

Tract 503

ED 175

EU 176

(E) 188

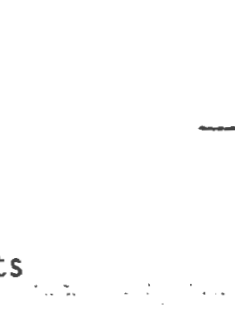

....... $8928 \quad 1320$

14.9

1418135

....... $3137 \quad 80$

9.5

2.6

$\ldots \ldots . . .584 \quad 31$

$\ldots \ldots \ldots 361 \quad 9$

....... $928 \quad 20$

......... 1264

........1162 604

20
604

..........211 4

$\ldots \ldots \ldots . . .333 \quad 333$

$\begin{array}{lr}\ldots \ldots \ldots .207 & 207 \\ \ldots \ldots \ldots \ldots 411 & 60\end{array}$

........486 - 301

…... 8

......... 295

$\ldots \ldots \ldots 000$

.......6.63 1

......... 00

........2337 113

....... $732 \quad 56$

........ $330 \quad 7$

$\ldots \ldots \ldots 1275 \quad 50$
5.3

2.5

2.2

1.6

52.0

1.9

100.0

100.0

14.9

61.9

62.5

71.1

1.6

4.8

7.7

2.1

3.9
Population

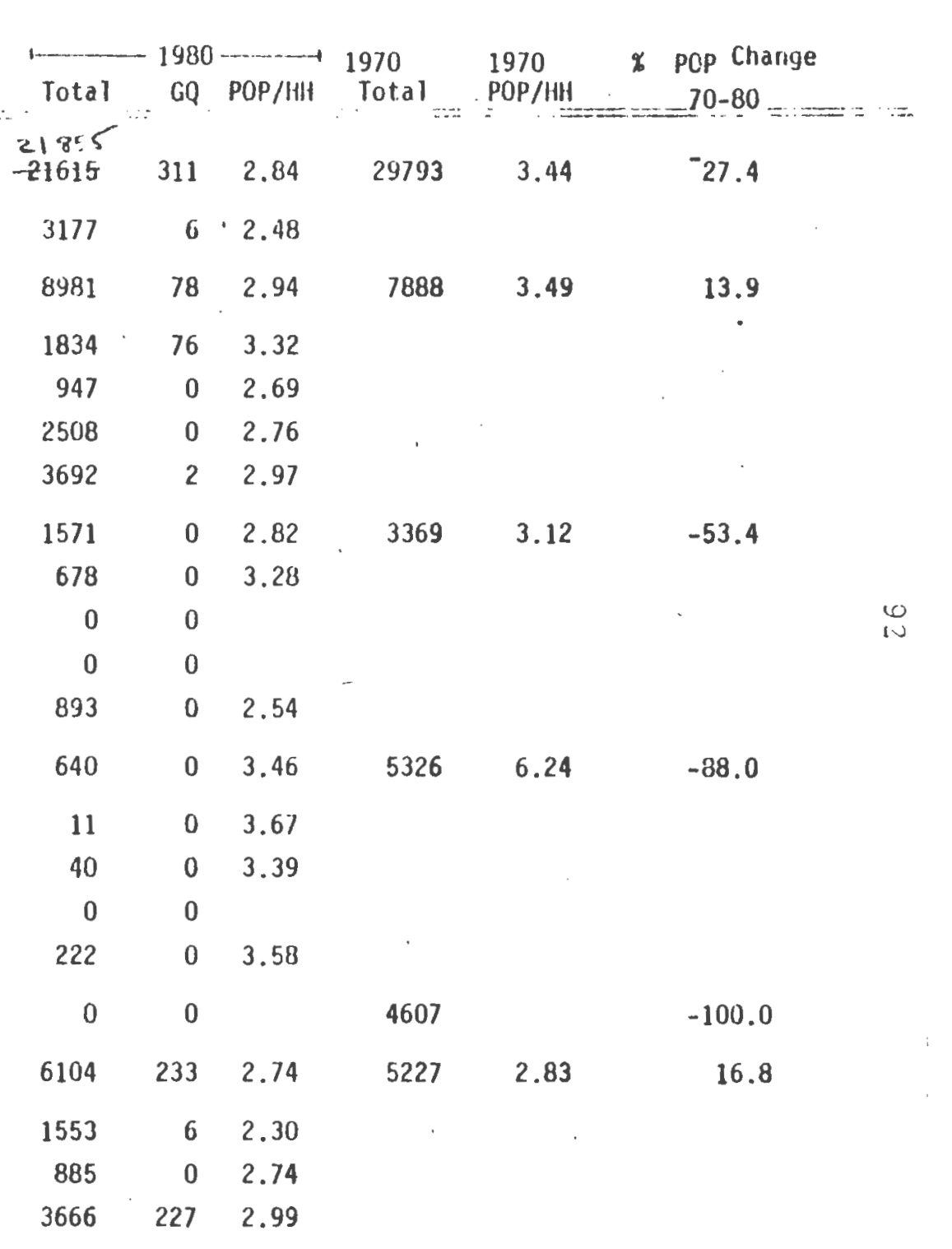




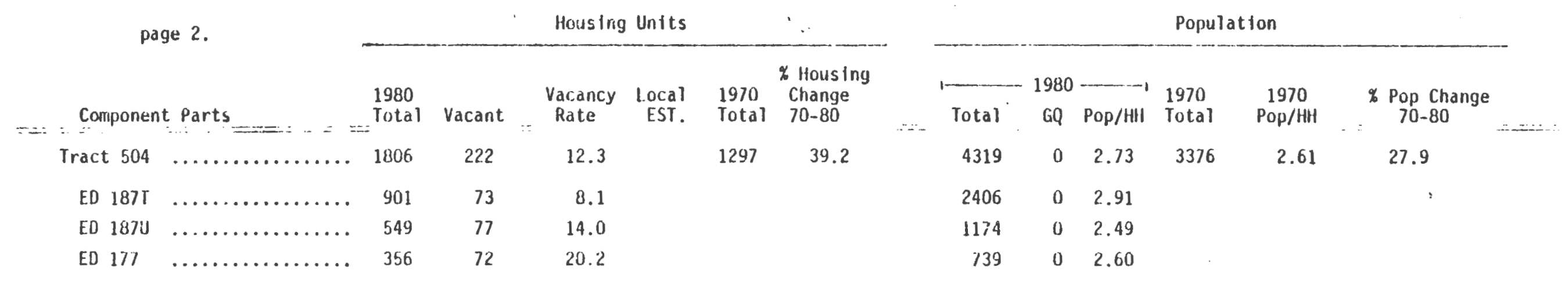


APPENDIX B

PROJECTED OCCUPATIONAL MIX 


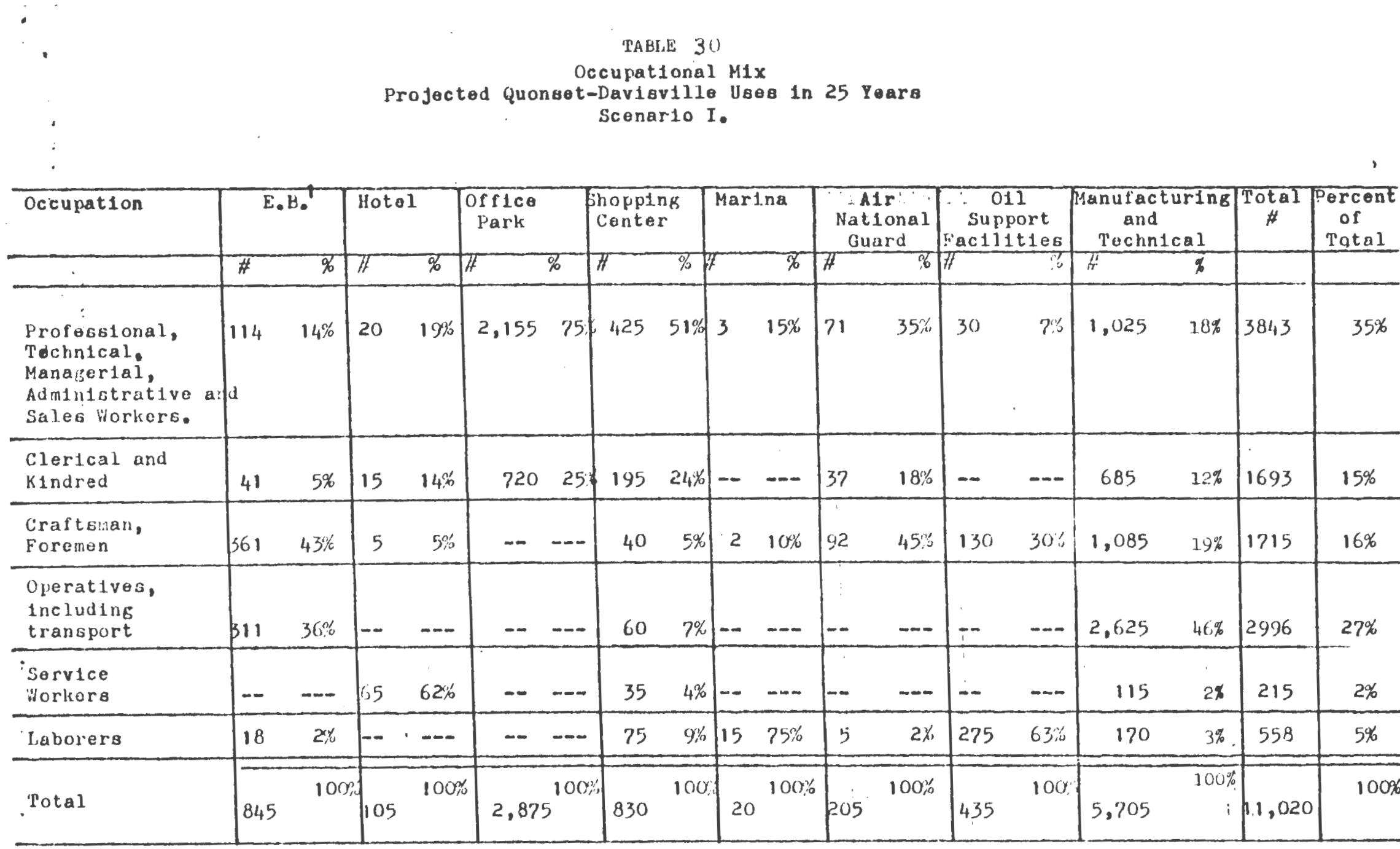

'(E.B.) is Electric boat of General Dynamics Corporation. These are the additional employeos expected from K. B. expansion in 25 years;

Source: Compllation of stat1stics from Susdr-Esonemic dssessment Alternatived of the beuse of Quenziet Davieville, Gladstone Assoclater, Appondix C. 1977. 
TABLE : 3 ]

Occupational MIX

Projected Quonet-Davisillo Usea in 25 Yeare

Scenario II.

\begin{tabular}{|c|c|c|c|c|c|c|c|c|c|c|c|c|c|c|c|c|c|}
\hline \multirow[t]{2}{*}{ Uccupation } & \multicolumn{2}{|c|}{ E. B. } & \multicolumn{2}{|c|}{ Hotel } & \multicolumn{2}{|l|}{$\begin{array}{l}\text { Offlco } \\
\text { Park }\end{array}$} & \multicolumn{2}{|c|}{$\begin{array}{l}\text { Shopplng } \\
\text { Center }\end{array}$} & \multirow{2}{*}{\begin{tabular}{|c|} 
Marina \\
$7 \%$
\end{tabular}} & \multicolumn{2}{|c|}{$\begin{array}{c}\text { Alr } \\
\text { Nattonel } \\
\text { Guard }\end{array}$} & \multicolumn{2}{|c|}{$\begin{array}{c}011 \\
\text { support } \\
\text { Fac111t } 108\end{array}$} & \multicolumn{2}{|c|}{$\begin{array}{c}\text { Manufacturing } \\
\text { and } \\
\text { Technlcal }\end{array}$} & \multirow[t]{2}{*}{$\begin{array}{c}\text { Total } \\
\#\end{array}$} & \multirow[t]{2}{*}{$\begin{array}{c}\text { Percent } \\
\text { of } \\
\text { Total }\end{array}$} \\
\hline & $\pi$ & क्ष & $\#$ & 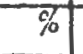 & 77 & $\mathscr{6}$ & $\pi$ & $\%$ & & 77 & 26 & 72 & $\%$ & $\not H$ & $\%$ & & \\
\hline $\begin{array}{l}\text { Profesatonal, } \\
\text { Pechnical, } \\
\text { Managerial, } \\
\text { Adinintstrativo } \\
\text { BghtSples }\end{array}$ & 114 & $14 \%$ & 20 & 199 & 2,155 & $75 \%$ & 425 & $51 \%$ & $315 \%$ & 71 & $35 \%$ & 20 & $7 \%$ & 1190 & $18 \%$, & 3998 & 34.6 \\
\hline $\begin{array}{l}\text { Clerical and } \\
\text { KIndred. }\end{array}$ & 41 & $5 \%$ & 15 & $142 \pi$ & 720 & $25 \%$ & 195 & $24 \%$ & $-\cdots$ & 37 & $18 \%$ & - & $-\infty$ & 795 & $1<\%$ & 1803 & $15 \%$ \\
\hline $\begin{array}{l}\text { Craftsmen, } \\
\text { Poremen. }\end{array}$ & 361 & $43 \%$ & 5 & $5 \%$ & $-\infty$ & & 40 & $5 \%$ & $210 \%$ & 92 & $45 \%$ & 90 & $30 \%$ & 1255 & $19 x$ & 1845 & $16 \%$ \\
\hline $\begin{array}{l}\text { Operat Ives, } \\
\text { Including } \\
\text { transport. }\end{array}$ & 311 & $36 \%$ & -- & $-\infty$ & $-\infty$ & & 60 & $7 x^{\prime}$ & $-\infty-\cdots$ & - & -- & -- & --- & 3040 & $1,6 \%$ & 3411 & $29 \%$ \\
\hline ServiceWorkera & $-\infty$ & $-\infty$ & 65 & $62 \%$ & -- & & 35 & $4 \%$ & ---- & - & --- & -- & $--\infty$ & 130 & $2 \%$ & 230 & $2 \%$ \\
\hline labncers. & 18 & $2 \%$ & - & --- & - & -- & 75 & $\mathscr{T}_{0}^{\prime \prime}$ & $1575 \%$ & 5 & $2 \%$ & 185 & $63 \%$ & 200 & $3 \%$ & 498 & $4 \%$ \\
\hline Tutal & 845 & $00 \%$ & 105 & $100 \%$ & 2,875 & 100 & 830 & $100 \%$ & $20^{100 \%}$ & 20 & $100 \%$ & 295 & $100 \%$ & 6,610 & $100 \%$ & 11,785 & $100 \%$ \\
\hline
\end{tabular}

'(E.B.) 18 klectric Boat Division of General Dynamica Corjuration. These are the additional employees expected from L. B. expancion in 25 year.6.

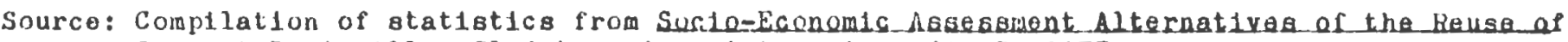
Quonset-Davigu士110, Gladstone Agooclates. Anpendix C. 1977. 
TABLE 3á

Occupational Mix

Projected Quoneet-Davisy1Ile User in 25 Yeare

Scenarto III.

\begin{tabular}{|c|c|c|c|c|c|c|c|c|c|c|c|c|c|c|c|c|}
\hline \multirow[t]{2}{*}{ Occupation } & \multicolumn{2}{|c|}{ E.B? } & \multicolumn{2}{|c|}{ Hotel } & \multicolumn{2}{|l|}{$\begin{array}{l}\text { Orfice } \\
\text { Park }\end{array}$} & \multicolumn{2}{|c|}{$\begin{array}{l}\text { Shopping } \\
\text { Center }\end{array}$} & \multicolumn{2}{|c|}{ Marina } & \multicolumn{2}{|c|}{$\begin{array}{c}\text { Alr } \\
\text { National } \\
\text { Guard }\end{array}$} & $\begin{array}{c}0112 \\
\text { Support } \\
\text { Factlitios }\end{array}$ & $\begin{array}{c}\text { Manufacturing } \\
\text { and } \\
\text { pechn1cal }\end{array}$ & \multirow[t]{2}{*}{$\begin{array}{c}\text { Total } \\
\#\end{array}$} & \multirow[t]{2}{*}{$\begin{array}{c}\text { Percent } \\
\text { of } \\
\text { Potal }\end{array}$} \\
\hline & $\not$ & $\not x$ & $\not H$ & $\%$ & $\#$ & क6 & $\pi$ & $\%$ & 7 & $\%$ & 7 & का & $\not 7$ & 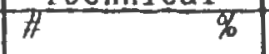 & & \\
\hline $\begin{array}{l}\text { Profeasional, } \\
\text { Tectinlcal. } \\
\text { Managerial, } \\
\text { Administrative } \\
\text { and Salos } \\
\text { Workers. }\end{array}$ & 114 & $14 \%$ & 20 & $19 \%$ & 2,155 & $75 \%$ & 425 & $51 \%$ & 3 & $15 \%$ & 71 & $35 \%$ & $-\infty$ & 1,220 & 4008 & $34 \%$ \\
\hline $\begin{array}{l}\text { Clerical and } \\
\text { Kindred. }\end{array}$ & 41 & $5 \%$ & 15 & 14.7 & 720 & $25 \%$ & 195 & $24 \%$ & -- & $-\infty$ & 37 & $18 \%$ & --- & 810 & 1818 & $16 \%$ \\
\hline $\begin{array}{l}\text { Craftemen, } \\
\text { Foremen. }\end{array}$ & 361 & $43 \%$ & 5 & $5 \%$ & -- & -- & 40 & $5 \%$ & 2 & $10 \%$ & 92 & $45 \%$ & -- & 1,285 & 1785 & $15 \%$ \\
\hline $\begin{array}{l}\text { Operat } 1 \text { ves, } \\
\text { Including } \\
\text { traneport. }\end{array}$ & 311 & $36 \%$ & - & $-\infty$ & - & $\cdots$ & 60 & $7 \%$ & $\infty$ & $-\infty$ & $-\infty$ & $-\infty$ & -- & 3,115 & 3486 & $30 \%$ \\
\hline Service Workere & $-\infty$ & --- & 65 & $62 \%$ & $-\infty$ & $--\infty$ & 35 & $4 \%$ & $-\infty$ & $-\infty$ & - & $--\infty$ & -- & 135 & 235 & $2 \alpha$ \\
\hline Laborers & 18 & $2 \%$ & $-\infty$ & $-\infty$ & - & -- & 75 & $9 \%$ & 15 & $75 \%$ & 5 & $2 \%$ & $-\infty$ & 205 & 318 & $3 \%$ \\
\hline Total & 845 & $100 \%$ & 105 & $100 \%$ & 2,875 & $100 \%$ & 830 & $100 \%$ & 20 & $100 \%$ & 205 & $100 \%$ & $\cdots--$ & $6,770^{100 \%}$ & 11,650 & $100 \%$ \\
\hline
\end{tabular}

'(E.B.) Is Electric Boat Division of General Dynanics Corporation. These are the additional employees expected from E. P. expanoton in 25 yoars.

${ }^{2}$ Scenario Ilf is a no oll ilud altecrutive, hence there are no emplovees expected.

Source: Comptlation ol statistics from Bocio-kecnomic Assessment Alternatives of the heuse of Quonset Davisville, (iikdstone Asjocjates. Appendix C. 1977. 


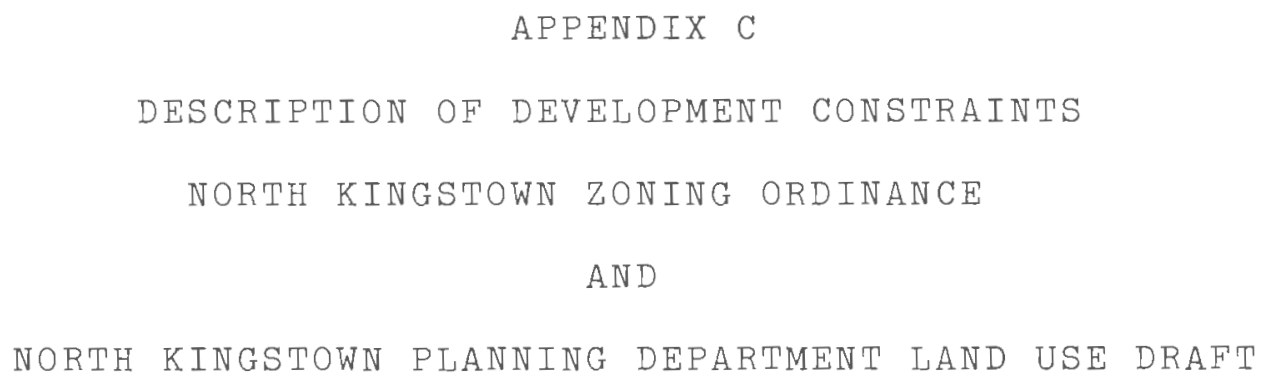




\section{ARTICLE VIII OVERLAY DISTRICTS}

17-8-1 Purpose of Article; Overlay districts establish additional requirements for the primary zoning districts based on specific hazards and problems outlined in the Soil Interpretation Tables prepared for the State of Rhode Island by the United States Department of Agriculture, Soil Conservation Service, and in the report of the United States Geological Survey on ground water resources*.

The administrative officer of the zoning ordinance shall detemine when an overlay district and its requiraments regulate the granting of a bullding pemit. The location of the primary structure shall determine the application of overlay requirements. An engineering soil survey to determine suitability of land for development, upon review of the Soil Conservation Service, shall supersede the Overlay District map.

* Hydrology, Potowomut-Wickford Area, Rhode Island, U.S.D.A. Geological Survey Water Supply Paper 1775. Rosenshein, Gauthier and Allen.

17-8-2 USE REGULATIONS; SPECIAL EXCEPTIONS: Within the limits of the Overlay Districts all requirements set forth in the primary district shall apply with the enumerated additions, exceptions and conditions.

The Zoning board shall request the Soil and Water Conservation District to make available expert assistance from those agencies which are assisting said district under a memorandum of understanding. Site plans must be approved by the Planning Director and Town Engineer before a building pemit can be issued.

Permission to alter a wetland does not alter the restrictions of any Overlay District.

\section{7-8-3 Very Severe Limitations District}

a. Designation: This district shall include all lands designated on map sheets of the Soil Survey of North Kingstown by the following symbols :

$\begin{array}{lllllll}4 & 9 & 19 & 20 & 21 & 23 & 31 \\ 34 & 34 X & 36 R & 38 & 39 & 55 & 63 \\ 65 & 65 X & 71 & 72 & 73 & 551 & \end{array}$

b. Characteristics: All soils designated by these symbols have very severe high water tables, peat and muck, tidal marsh, or a flood hazard.

c. Permitted uses: Any use permitted in the primary zoning district which does not require a basement or a subsoil sewage disposal - systen. 


\section{7-8-4 Severe Limitations District}

- Designation: This district shall include all lands designated on map Theets of the Soll Survey of the Town of North Xingstown as having severe limitations and including the following symbols:

\begin{tabular}{|c|c|c|c|c|c|c|c|c|c|c|c|c|}
\hline 2 & $2 M$ & $3 \times D$ & $5 A$ & $5 B$ & $5 \times 4$ & $5 \times B$ & $5 \mathrm{~KB}$ & 6 & $6 x$ & $7 H$ & $10 A$ & $10 B$ \\
\hline 100 & $20 \times B$ & $10 \times C$ & $10 \times 0$ & IOMC & $10 \mathrm{MD}$ & ILA & $11 B$ & 12 & $12 \mathrm{~A}$ & $12 \mathrm{~B}$ & $14 \mathrm{MD}$ & $29 A$ \\
\hline $29 B$ & 30 & 32 & $34 M$ & $36 L C$ & $36 \mathrm{MC}$ & $37 L C$ & $37 M C$ & $37 \mathrm{MD}$ & 400 & 4OMD & $42 \mathrm{~A}$ & $42 B$ \\
\hline $42 \mathrm{XA}$ & $42 \times 0 B$ & $42 \mathrm{MA}$ & $42 \mathrm{MB}$ & 44 & 45 & $47 \mathrm{~A}$ & $47 B$ & $47 X A$ & $47 \times B$ & 47MA & $47 \mathrm{MB}$ & 48 \\
\hline $48 x$ & 53 & $53 \mathrm{M}$ & 54 & 61 & $64 A$ & $64 \mathrm{~B}$ & $64 \mathrm{MB}$ & 66 & $66 x$ & $67 \mathrm{~A}$ & $67 \mathrm{~B}$ & $67 M C$ \\
\hline $67 \times B$ & 68 & $68 B$ & 69 & $69 B$ & & & & & & & & \\
\hline
\end{tabular}

b. Characteristics: All soils designated by these symbols have periodic or constanthign water tables, very slow permeability, severe fragipan, severe stoniness or shallow depths to bedrock - conditions which severely limit the proper functioning of on-site sewage disposal systems:

c. Permicted Uses: Any use permitted by the primary zoning district.

d. Mintmum Restrictions: No lot shall be recorded as a building lot in the land evidence records with any portion in a Severe Limitations District unless: 1) public sewerage or 2) epproval for an on-site sewage disposal system tas been received from the Rhode Is land Departuent of Health.

\section{7-8-5 Steep Slope Overlay District}

a. Deslgnation: This district shall include all lands designated on map sheets of the Soil Survey of North Kingstown by the following symbois:

$$
\text { 15D 25D 46D }
$$

b. Characteristics: These solls pose speclal problems in building construction and may be subject to severe erosion. On-site sewage disposal systems must be carefully installed.

c. Permitzed Uses: Any use which is permitted by the primary zoning district provided:

1) - the proposed structure shall be of sound englneering destgn with footings designed to extend to stable rock or soil

2) - access roads and ocher land clearing shail be designed to avold excessive erosion and to maintain scenic values.

3) - leaching fields are laid out with consideration for the slope and contours of the land. 
d. Site Plan: All proposed uses shall submit a site plan for approval by the Town Engineer and the Planning Director.

17-8-6 Ground Water Recharge Overlay District.

- Designation: This district includes all land in North Kingstown described in the report of the United States Geological Survey on ground water resources*, upstream of any public well site and lying within the drainage basins of the Hunt, Annaquatucket and Pettasqumscutt RIvers, and having a transmissivity greater than 0 gallons per day per foot.

b. Charactertstics: The character of solls and subsoll conditions is such in these areas that any use introducing pollutants into the natural drainage system could adversely affect the quality of munlcipal drinking water sources.

c. Permitted Uses: Any use permitted in the primary zoning district which discharges efiluent into the ground that meets the chemical standards of the United States Environmental Protection Agency.

d. Special Exceptions:All other uses permitted in the primary zoning district provided that proof be submitted that the proposed use will not cause pollution.

e. Minimum Requirements: Minimum requirements shall be as specified in the primary zoning district.

17-8-7 Ground Water Reservoir Overlay District.

a. Designation: The Ground Water Reservoir Overlay District includes all lands in North Kingstown described as having a saturated thickness of over 40 feet and a transmissivity greater than 60 thousand gallons per day in the report of the United States Geological Survey*.

b. Characteristics: The lands in the Ground Water Reservoir Overlay District are the principal source of drinking water in North Kingstown. As such they must carefully be protected from pollution.

c. Permitted Uses are single family residential, recreation, conservation and agriculcure.

d. Minimum Requirements:

1. Maximun Lot Coverage: 20\%

2. Lot Area: 3 acres, $300^{\prime}$ Frontage, or

3. Average density: $1 / 3$ dwelling unit per acre

* Eydrologic Characteristics and Sustained Yield of Principal Ground Water Untes, Potowomut-lickford Area, Shode Island. 
Constraints to Development

Natural Features

Soils \& Slopes

Each soil type has properties which affect its suitability for different types of development. In recent years, communities have paid increasing attention to soil suitability when making determinations about land use. North Kingstown was the first Rhode Island municipality to have its soils mapped by the U.S. Soil Conservation Service, and it is the only community which bases some of its development regulations on the findings of the soil survey.

Among the soil characteristics which affect development are permeability, bearing strength, depth to bedrock, depth to seasonal high water table, erodability and stability, and the resource value of the soil (for building material, road fill, ecricuiture, etc.). The soil survey for liorth Kingstown evaluates the properties of the various soils found in the town in terms of their development limitations.

Some examples may help to demonstrate the relationship between soil characteristics and development. The Soil Conservation Service classifies anj land which has less than 20 inches of soil over bedrock to have severe limitations for ali construction. On-site sewage disposal is not advisable in such soils, because the thin soil cannot efficiently absorb and filter wastes. Road construction in these soils is costly, because large amounts of blasting, excavation, and fill are needed. The types and numbers of structures which can be built are limited by the amount of load they place on the bedrock and the strength of the bedrock itself.

A high water table increases the likelihood of flooding and reduces the efficiency of ori-site sewage disposal systems. Soil texture affects the movement of water and the water-holding capacity of the earth, and this water-holding capacity in turn influences the growth of trees and shrubs.

Areas of steep slope obviously create development problems. Excavation ant. grading related to construction on such slopes is expensive, and there is a high potential for environmental damage from such construction. When ground covers on steep slopes ere removed, the land becomes highly susceptible to soil erosion. Terracing or levelling such slofes for development purposes increases the potential for flood damage and destroys the natural topography.

A certain amount of soil erosion occurs naturally, but excessive erosion. is a source of sedimentation in waterways, and it robs the land of oroductive topsoil. Construction activities and agriculture both can contribute to soil erosion if proper practices are not foilowed. 
The Rhode Island Areawide Water Quality Managerient Study identified eight sites covering 406 acres in North Kingstown where there are erosion and sediment problems resulting from agricultural activity. Of these eight, six are listed as "slight" problems, with an annual soii loss of less than ten tons per acre. One 66-acre site, off Hatchery Road near the Exeter town line, is listed as a "moderate" problem, with a soil loss of 10 to 20 tons per acre per year. Part of this area has since been converted to residential use. There is only one "severe" problem site listed in North Kingstown, a gully located on agricultural land south of Indian Corner Road in Slocum. The soil loss from this site is more than 20 tons per acre per year.

Soil loss from agriculture can be prevented through such good farming practices as applying cover crops, contour faming, and crop rotation. White there may be an initial expense for famers to employ such practices, there are long-term benefits in preventing the loss of valuable topsoil.

By iar the most serious source of erosion in North Kingstown is construc:ion activity. Throughout the state, soil loss from constructicn activity is three times greater than that from untreated cultivated land. Erosion and runoff of sediments can be controlled effectively and economically by proper practices during and after land-disturbing activities.

The existence of soil limitations does not necessarily mean that a particular parcel of land cannot be developed, but some soils ciearly are more suited to one type of use than another, and where limitations exist, the development costs wili be higier. In some cases, development on an unsuitable soil may lead to permanent loss of an aesthetic or natural resource. Flood hazards can be increased, as can the amount of standing water which serves as breeding places for mosquitoes. Good agricultural land may be lost to highways, shopping centers, and houses. The use of soil surveys in the planning process can help prevent costly mistakes in locating various types of deveiopment.

\section{Wetlands, Water Bodies and Floodplains}

Perhaps the dominant physical characteristic of North Kingstown is its abundant water resources. The town has 31 miles of salt water coastline, three rivers and associated tributaries, thirteen ponds larger than five acres, three groundwater reservoirs, and acres of wetlands, including bogs, marshes and swamps.

In addition to supplying the residents of the community with water for drinking and other purposes, this system of streams, ponds and wetlands form the natural drainage system for the town. Disruption of the system affects both the quality and the quantity of the water, and it can cause flooding, erosion, and other environmental problens. The need to protect these important resources significantly affects the location and extent of development which should be allowed to take place in North kingstown.

Residents of North kingstown depend upon high-quality ground water supplies as sources of pctable water. The zquifers from which this water is extracted must be protected from contamination. In addition, there must be controls placed on the recharge areas for these ground water supplies. 
Frashwater wetlands are important habitats for plants and wildlife, and they serve an important water-holding function. The filling of wetlands can cause streams and ponds to overfiow, and it can contribute to pollution of fresh waters, because the wetlands serve as fiiters for sediments and other pollutants. In addition, because North Kingstown will continue to be dependent upon individual subsurface waste disposal systems for some time, development in wet areas is impractical, as wet soils have limited capacity to absorb wastes.

Coastal ponds and wetlands are recognized under the Federal Coastal Zone Management Act and the state's coastal resources management program to be critical natural areas which mlist be protected. They are primary habitats of many forms of aquatic fish and plant life, and they have fragile ecosystems which can be adversely effected by many activities of man.

Flocdplains also should be protected from indiscriminate development, as they serve as water storage areas. Deveiopnent reduces the water-holding capacity wich in turn increases the rate of flow into the receiving waters during periods of heavy precipitation, causing downstream flooding and erosicn.

Water bodies and wetlands aiso seme important aesthetic functions, and many of them have recreational potential. The value of these resources easily can be destroyed by conversion of land from its naturai state to houses, roads, and office buildings. Increases in the amount of imeervious surfaces contribute to poliution from stomwater runoff. Private construction alorig shorelines recuces fublic access to the waterfront. Despite North Kingstown's lengthy coastline along Narragansett Bay, there is little pubiic access to the shore, because most of the coastal land is in private ownership.

According to the state's water quality classification program, most of North Kingstown's waters are of high quality, suitabie for fishing and swiming. The Federal Clean water Act established a goal for the ration of achieving fishable, swimable water quality wherever possitle by 1983 . Nearly all of North Kingstown's waters meet that goal at present, but unwise develooment could cause significant deterioration of the water quality.

The Rhode Island Areawide Quality Management Plan included a study of the relationships of land use to water quality and made a number of recommendations aimed at protecting existing high-quality waters in the state. The recomimendations from that study have been taken into account in the preparation of this land use element.

\section{Other Natural Constraints}

\section{Water Suppiy}

An important factor in determining the ability of

North Kingstown to absorb growth is the availability of water. The town has faced shortages during summer droughts for several years, and additional water customers will tax the supplies further unless the capacity of the system is increased. Continuing increases in per capita consumption of water alse are a factor. 
In addition to the town's water system, there are a number of private wells supplying town residents. The total amount of water drawn from all sources in the town must not, of course, exceed the amount which is replenished by precipitation, unless it intends to purchase water from another jurisdiction. The town's growth, then, is limited by the total amount of water which can be supplied and by the rate at which the systern capacity can be increased.

- Areas of Natural Significance

In addition to the categories of natura? resources which have been discussed here, there may be specific sites which should be protected from development because of particular significance. Examples are unusual landforms, habitats for rare or endangered species of flora or falina, or areas of special scenic beauty. Such areas should be identified and preserved.

\section{Historica! and Archeological Sites}

Features of historical and archeologicai significance are important to North Kingstown's local identity. Section I outlined the community's historic development. Meny sites representing a distinguished past still remain, and care must be taken to assure that the variety of local historical features are not lost to modern development.

Along with remnants from the past which are currently visable to the eye, the archeological record is a source of information about North Kingstown's early years, and this, too, should be preserved, as once this record is obliterated it can never be replaced. 
APPENDIX D

RESIDENTIAL ZONING CATAGORIES 
Article II. RESIDENTIAL DISTRICTS

\section{7-2-1 RURAL RESIDEIUTIAL}

The Rural Residential District is established to protect the rural landscape and to conserve natural resources.

A. PERMITTED USES:

1. Single-family dwelling

2. Farm, truck garden, plant nursery, forestry

3. Municipal structure or use

4. Cluster development

5. Private school

5. Nursing or convalescent home

7. Residential compound, Section 17-9-4

8. Accessory uses:

a. The sale of farm, garden or nursery products grown on site or of animals raised on the premises.

b. Storage space for not more tinan eleven (11) vehicles.

c. A temporary sales office or temporary storage of building supplies as an accessory to a real estate subdivision or development.

d. Customary home occupation such as physician, engineer, insurance agent, lawyer, real es tate broker, beauty parlor or other professional person, provided tnat the person resides in the house, and employs no more than two persons.

e. Not more than two rooms rented or tableboard furnished incidental to a private residence lise.

f. Any use or bujlding clearly accessory to an authorized use, provided that no use enumerated as a business use in Article iV shall be allowed as an accessory use except those specificaliy provided for.

g. The use of a residential dwelling unit as a Family Day Care Home.

B. SPECIAL EXCEPTIONS, where consistent with the definition of the district or where reasonably necessary for the convenience or welfare of the public.

3. Non-profit activities such as a church, museum or charitable institution.

2. Day care center

3. Nursery school

4. Animal nospital, provided a $100^{\prime}$ setback is maintained from side and rear lot lines, without outdoor boarding.

5. Hospital or medical clinic

6. Commercial recreation

7. One rental unit

8. Mobile home

9. Utilities and comunications uses

10. Cemetery 
1i. Earth removal

12. Neightornocd business

13. Travel trailer park or camping area

14. Animal boarding Kennel

C. MINIMUM REQUIREMENTS

1. Dimerisions for Lots

\begin{tabular}{|c|c|c|c|c|}
\hline $\begin{array}{l}\text { Type } \\
\text { Unit }\end{array}$ & $\begin{array}{l}\text { Size } \\
\text { Sg.Ft. }\end{array}$ & $\begin{array}{c}\text { Frontage } \\
\text { Feet }\end{array}$ & $\begin{array}{l}\text { Depth } \\
\text { Feet }\end{array}$ & $\begin{array}{l}\text { Rear \& Side } \\
\text { Yds. - Feot } \\
\end{array}$ \\
\hline \multirow{2}{*}{$\begin{array}{l}\text { Dwelling } \\
\text { Cther Permitted } \\
\text { lises }\end{array}$} & 80,000 & 200 & 250 & 35 \\
\hline & $\begin{array}{l}5 \text { Acres or } \\
3,000 \text { sq.ft. } \\
\text { per bedroom* }\end{array}$ & 300 & 300 & 35 \\
\hline \multirow{6}{*}{$\begin{array}{l}1 \text { Story Acc. Usa } \\
2 \text { Story Acc. Use } \\
\text { Mobile Hone } \\
\text { Res. Compound } \\
\text { Day Care Center, } \\
\text { nursery school or } \\
\text { non-profit activity } \\
\text { Neighborhood Bus. }\end{array}$} & - & - & - & 25 \\
\hline & - & - & - & 25 \\
\hline & 5 Acres & 300 & 300 & 35 \\
\hline & 10 Acres & 200 & 250 & 35 \\
\hline & 30,000 & 200 & 250 & 35 \\
\hline & & & & \\
\hline \multirow{2}{*}{$\begin{array}{l}\text { Use } \\
\text { Other Special Exc. }\end{array}$} & $\begin{array}{l}80,000 \\
5 \text { acres or }\end{array}$ & 200 & 250 & 35 \\
\hline & per bedrocm* & 300 & 300 & 35 \\
\hline
\end{tabular}

*Whichever is greater

2. Rentai Unit: One rental unit may be allowed in either the principal structure or in an existing accessory structure provided:

a. Not less than ten (10) square feet of open space for each one (1) square foot of floor area of the apartment is provided over the minimum lot size required for the principal dwelling.

b. The principal structure must contain at least 2500 square feet or the accessory structure 1000 square feet. 
17-2-2 NEIGHBORHOOD RESIDEITTIAL

The Nefghborhood Residential District is established to promote low density neighborhood growth in areas with natural limitations for development.

A. PERMITTED USES:

1. A use authorized in Rural Residential District a

2. Accessory uses:

a. A use authorized as an accessory use in Rural Residential District

b. Storage space for not more than four (4) vehicles.

B. SPECIAL EXCEPTIONS, where consistent with the definition of the district or reasonably necessary for the convenience or welfare of tne public.

i. Non-profit activities such as a church, museum or charitable institution.

2. Day care center

3. Nursery scinool

4. Hospitai or medical clinic

5. One rental unit

6. Utilities and communication uses

7. Cemetery

C. MINIMUM REQUIREMENTS

1. Dimensions for Lots

\begin{tabular}{|c|c|c|c|c|}
\hline $\begin{array}{l}\text { Type } \\
\text { Unit }\end{array}$ & $\begin{array}{l}\text { Size } \\
\text { Sq.Ft. }\end{array}$ & $\begin{array}{l}\text { Frontage } \\
\text { Feet } \\
\end{array}$ & $\begin{array}{l}\text { Depth } \\
\text { Feet }\end{array}$ & $\begin{array}{l}\text { Rear \& Sid } \\
\text { Yds. - Ft. }\end{array}$ \\
\hline $\begin{array}{l}\text { Dwelling } \\
\text { Other Permitted }\end{array}$ & 40,000 & 180 & 200 & 35 \\
\hline Uses & $\begin{array}{l}3,000 \text { sq. ft. } \\
\text { per bedroum* }\end{array}$ & 300 & 300 & 35 \\
\hline $\begin{array}{l}1 \text { story Acc. Use } \\
2 \text { story Acc. Use }\end{array}$ & - & - & - & $\begin{array}{l}25 \\
35\end{array}$ \\
\hline $\begin{array}{l}\text { Day care center, } \\
\text { Nursery school, or } \\
\text { Non-profit activity }\end{array}$ & 40,000 & 180 & 200 & 35 \\
\hline Other Special Excep. & $\begin{array}{l}5 \text { acres or } \\
3,000 \text { sq.ft. } \\
\text { per bedroom }\end{array}$ & 300 & 300 & 35 \\
\hline Residential Cmpd. & 5 acres & 200 & 250 & 35 \\
\hline
\end{tabular}

*hiciever is greater

2. Rental Unit, as authorized in the Rural Residential District 


\section{7-2-3 VILLAGE RESIDENTIAL}

The Village Residential District is established to protect and promote the convenience and character of compact village settlements designed to complement the natural features of the land.

A. PERHITTED USES:

1. A use authorized in Rural Residential District

2. Twc-family dwelling

3. Accessory uses:

a. A use authorized as an accessory use in Rural Residential oistrict b. Storage space for not more than four (4) vehicles.

8. SPECIAL EXCEPTIOilS, where consistent with the definition of the district or where reasonably necessary for the convenience or welfare of the public.

1. Non-profit activities such as a church, museum or other charitable organization

2. Day care center

3. Nursery scincol

4. One rental unit

5. Mobile home oark

6. Utilities and comunication uses

7. Cemetery

C. MINIMUH REQUIREMENTS

1. Dimensions for Lots

Type

Unit

Size Sq.Ft. Frontage Depth Feet Rear \& Side

Stngle-Fam. Owelling

Two-Fam. Owelling 20,000 40,000 Feet Yds. - Ft.

Other Permitted Uses

1 story Acc. Use

2 story Acc. Use

Day care center, Mursery scnool, or non-profit activity Other special Excep. Residential Compound

5 acres or 3,000 sq.ft. per bedroom*
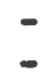

40,000

5 acres

5 acres
140

165

200

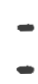

165

200

200
140

160

160

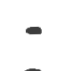

-

160

160

250
15

15

15

5 .

15

15

15

35

*Whichever is greater

2. Rental Unit, as authorized in the Rural Residential District

3. Mobile Home Park: A mobile home park may be permitted, subject to density and site design standards of the Building Code.

The site plan shall be approved by the Planning Cormission prior to any issuance of a building permit by the Building Inspector. 


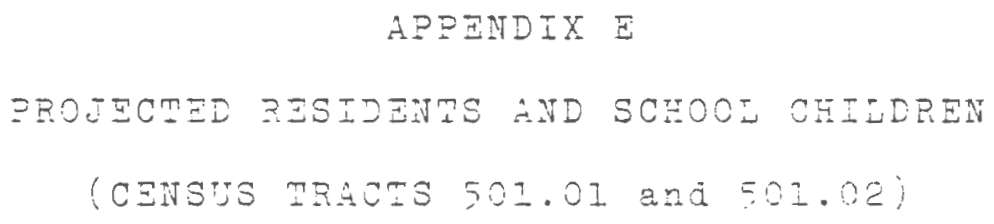


TABLE. 33

Quonset-llav1sv1110

Rolated Regident and School Age Chiliren

liensus Tract 501.01

\begin{tabular}{|c|c|c|c|c|c|c|c|c|c|c|c|}
\hline \multirow{4}{*}{$\begin{array}{l}\text { Typos of } \\
\text { Roaldential } \\
\text { Develonment }\end{array}$} & \multirow{4}{*}{$\begin{array}{l}\text { (1) } \\
\text { Persons } \\
\text { Per lin. }\end{array}$} & \multirow{4}{*}{$\begin{array}{l}\text { (2) } \\
\text { School } \\
\text { Ch1ldren } \\
\text { Per llh. }\end{array}$} & \multicolumn{3}{|c|}{ 100\% option } & \multicolumn{3}{|c|}{$75 \%$ Option } & \multicolumn{3}{|c|}{$50 \%$ option } \\
\hline & & & & (4) & $\begin{array}{c}(5) \\
\text { school }\end{array}$ & & (7) & $\begin{array}{c}(8) \\
\text { School }\end{array}$ & (9) & $(10)$ & $\begin{array}{c}(11) \\
\text { School }\end{array}$ \\
\hline & & & Housing & Rosidenta & Ch1ldren & Hous1ng & Residenta & children & Housing & Residente & ch1ldren \\
\hline & & & Undta & $(1) \times(3)$ & $(2) \times(3)$ & Un $1 t_{a}$ & (1) $\times(6)$ & $(2) \times(6)$ & Un1to & (1) $\times(9)$ & $(2) \times(9)$ \\
\hline \multicolumn{12}{|l|}{ Alternative } \\
\hline 100\% Single & & & & & & & & & & & \\
\hline & 3.931 & 1.212 & 1286 & 5055 & 1559 & 964 & 3789 & 1168 & 61,3 & 2528 & 779 \\
\hline \multicolumn{12}{|l|}{ A) ternative ${ }_{2}$} \\
\hline $\begin{array}{l}\text { :out singlo } \\
\text { ram11y }\end{array}$ & 3.931 & 1.212 & 900 & 3538 & 1091 & 675 & 2653 & 818 & 450 & 1769 & 545 \\
\hline $20 \%$ Townhouses & 2.200 & $.345^{(4)}$ & 257 & 565 & 89 & 193 & 1,25 & $6 ?$ & 129 & 284 & 44 \\
\hline $10 \%$ A partments & 2.1111 & $.174_{4}$ & 129 & 273 & 22 & 96 & 203 & 17 & 64 & 135 & 11 \\
\hline Totals & & & 1286 & 4376 & 1202 & 964 & 3281 & 902 & 643 & 2188 & 600 \\
\hline \multicolumn{12}{|l|}{ A] ternactvet 3} \\
\hline $\begin{array}{l}50 \% \text { Single } \\
\text { Family }\end{array}$ & 3.931 & 1.212 & 61,5 & 2528 & 779 & 482 & 1895 & 584 & 322 & 1266 & 390 \\
\hline 40, Townhouses & $2 . \overline{200}$ & .345 & 514 & 1131 & $17 ?$ & 386 & 849 & 133 & 257 & 565 & 89 \\
\hline Tơ Apartmento & 2.111 & $.171_{1}$ & 12.9 & 273 & 22 & 96 & 303 & 17 & 64 & 135 & 11 \\
\hline Totals & & & 1286 & 3932 & $9 \overline{78}$ & 964 & 2947 & 734 & 643 & 1966 & 490 \\
\hline
\end{tabular}

"Persons per. househuld, Hortliesist average:i. The Hiscal Impact Handbock, Fixhlb1t 2-4, n. 34.

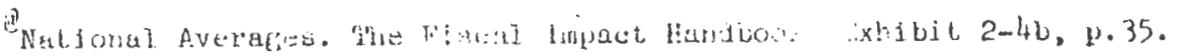


TABLE $3 \%$

Qu onset-Davisu11le

Rolated Residente and School Age Chyldren

Consua Tract 501.02

\begin{tabular}{|c|c|c|c|c|c|c|c|c|c|c|c|}
\hline $\begin{array}{l}\text { Types of } \\
\text { Residential } \\
\text { Devoloprent }\end{array}$ & $\begin{array}{l}\text { (1) } \\
\text { Person" } \\
\text { yer Hh. }\end{array}$ & $\begin{array}{c}\text { (2) } \\
\text { School } \\
\text { Uhildren } \\
\text { Jer Hh. }\end{array}$ & $\begin{array}{c}\text { (3) } \\
\text { Houging } \\
\text { Un1ts } \\
\end{array}$ & $\begin{array}{l}\text { 00\% Option } \\
\text { (4) } \\
\text { Residente } \\
\text { (1) } \times(3)\end{array}$ & $\begin{array}{l}\text { (5) } \\
\text { School } \\
\text { ch1 ldren } \\
(2) \times(3)\end{array}$ & $\begin{array}{l}\text { (6) } \\
\text { Housing } \\
\text { Unite } \\
\end{array}$ & $\begin{array}{l}75 \% \text { option } \\
(7) \\
\text { Residents } \\
(1) \times(6)\end{array}$ & $\begin{array}{l}\text { (8) } \\
\text { school } \\
\text { ch11dren } \\
\text { (2) } \times(6)\end{array}$ & $\begin{array}{l}\text { (9) } \\
\text { Housing } \\
\text { Undte }\end{array}$ & $\begin{array}{c}50 \% \text { option } \\
(10) \\
\text { Honident } \\
\text { (1) } \times(9)\end{array}$ & $\begin{array}{c}(11) \\
\text { school } \\
\text { children } \\
(2) \times(9)\end{array}$ \\
\hline \multicolumn{12}{|c|}{ (1) } \\
\hline $\begin{array}{l}100 \% \text { single } \\
\text { Fam1ly }\end{array}$ & 3.931 & 1.212 & 813 & 3196 & 985 & 610 & 2398 & 739 & 406 & 1596 & 492 \\
\hline \multicolumn{12}{|l|}{ Alternative ${ }_{2}$} \\
\hline $\begin{array}{l}70 \% \text { single } \\
\text { Family }\end{array}$ & 3.931 & 1.212 & 569 & 2237 & 690 & 427 & 1678 & 518 & 284 & 1116 & 342 \\
\hline $20 \%$ Townhouses & 2.200 & $.345^{8}$ & 163 & 359 & 56 & 122 & 268 & 42 & 81 & 178 & 28 \\
\hline $10 \%$ Apartment $B$ & 2.114 & .174 & 81 & 171 & $1 t_{t}$ & 61 & 129 & 11 & 41 & 87 & 7 \\
\hline Totals & & & 813 & 2767 & 760 & 610 & 2075 & 571 & 4,06 & 1381 & 377 \\
\hline \multicolumn{12}{|l|}{ Alternative 3} \\
\hline $\begin{array}{l}50 \% \text { Single } \\
\text { Family }\end{array}$ & 3.931 & $1: 212$ & 406 & 1596 & 492 & 305 & 1199 & 370 & 203 & 798 & 246 \\
\hline $40 \%$ Townhouse日 & 2.200 & .345 & 325 & 715 & 112 & 21,4 & 537 & 84 & 162 & 356 & 56 \\
\hline $10 \%$ Apartments & 2.114 & .174 & 81 & 171 & 14 & 61 & 129 & 11 & 41 & 87 & 7 \\
\hline Totals & & & 813 & 2482 & 618 & 610 & 1490 & 465 & 406 & 1241 & 309 \\
\hline
\end{tabular}

"Iersong per lloubenold. Northeast averaces. Tho F1ical Impact Handhonk, Exh1bit 2-4, p.34.

National averagoa. Tho Fiscal Impact Haudbook, Exlitht: 2-40, p.35. 


\section{B I BL IOGRAPHY}

Burche11, Robert $W$. , and Listokin, David. The Fiscal Impact Handbook. New Brunswick, N.J.: Center for Urban Policy Research, 1980.

Coastal Resources Center. Marine Technical Report \#55. The Redevelopment of Quonset-Davisville: An Environmental Assessment. Kingston, R.I.: University of Rhode Island, 1977 .

Economic Development Administration. A Handbook for Community officials and Others Engaged in the Conversion Process. Guide for Communities Planning Civilian Reuse of Defense Installation. Washington, D.C.: Economic Development Administration, March 1974.

Economic Development Corporation. Quonset-Davisville Agreement between North Kingstown and Rhode Island Port Authority and Economic Development Corporation. Rhode Island: Economic Development Corporation, April 28, 1980.

General Services Administration and VTN Consolidation, Inc. (Consultants). Administrative Action: Disposal of Surplus Federa1 Military Properties in Rhode Island. Washington, D.C.: General Services Administration, April 1978 .

General Services Administration and VTN Consolidation, Inc. (Consultants). Draft of the Environmental Impact Statement. Executive Summary. Administrative Action: Disposal of Surplus Federal Military Properties in Rhode Island. Washington, D.C.: General Services Administration, April 1978 .

Gladstone Associates. Socio-Economic Assessment of the Reuse Alternatives of Quonset Point and Davisville, R.I. Rhode Island: Department of Economic Development, August 1977 .

Gladstone Associates and Stah1/Bennett, Inc. Rhode Island Military Housing Study: Final Report. Rhode Island: Gladstone Associates, November 1975.

Hammer, Siler, and George Associates. Report to the Rhode Island Department of Economic Development. Market Analysis: Recreation Complex Quonset Point, Rhode Island. Rhode Island: Hammer, Siler, and George Associates, July 1975. 
Harbridge House, Inc. Report to the Rhode Island Department of Economic Development. Executive Summary. Industrial and Commercial Marketability of Surplus Properties in Rhode Island. Boston, Mass.: Harbridge House, Inc., Apri1 1976,

Keyes Associates. Report to the Rhode Island Department of Economic Development. Quonset Point Technical Park: Facilities Study. Providence, R.I.: Keyes Associates, March 1977.

Lombardo, Joseph D. The Economic Impacts of Navy Cutbacks. Rhode Island: Department of Economic Development, May $18,1977$.

New England Regional Commission. Report to the Rhode Island Office of the Governor. Fiscal Impact Study of North Kingstown, Rhode Island. Providence, R.I.: Rhode Is 1 and Office of the Governor, May 1978.

North Kingstown Department of Planning and Development. "Community Guide Plan: Element 4 Public Facilities Plan." North Kingstown, R.I.: Department of Planning and Development, 1981. (Draft.)

North Kingstown Department of Planning and Development. North Kingstown Community Guide Plan Element 1: Goals and Policies. North Kingstown, R.I.: Department of Planning and Development, February 1980.

North Kingstown Planning Department. Community Development Plan. North Kingstown, R. I.: Planning Department, September 1972 .

North Kingstown Planning Department. Housing Element: 1979 Update. North Kingstown, R.I.: Dlanning Department, Ju1y, 1979.

North Kingstown Planning Department. Quonset Reuse Plan. North Kinstown, R.I.: Planning Department, June 1975.

North Kingstown Planning Department. Servicing QuonsetDavisville. Report to the Town Council. North Kingstown,

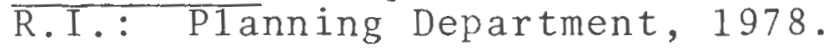

North Kingstown Planning and Development Department. "North Kingstown Community Guide Plan, Land Use Element." North Kingstown, R.I.: Planning Department, 1981. (Draft.)

Rhode Island Statewide Planning Program. Report Number 22: State Land Use Policies and Plan. Providence, R.I.: Statewide PIanning, January 1975. 
Rhode Island Statewide Planning Program. Rhode Island Population Projections by County, City, and Town. Technical Paper Number 83. Providence, R.I.: Statewide Planning Program, April 1979.

Rhode Island Statewide Planning Program. Technical Paper Number 92: Industrial Zoning Guidelines. Providence, R.I.: Statewide Planning, October 1980.

Spinard, Ted. "State Land Holdings at Quonset-Davisville." Memo to the Economic Development Corporation, Providence, R.I., Apri1 12, 1981.

Tischler, Marcou, and Associates, Inc. Fiscal Impact Study, North Kingstown, R.I. MUNIES Report. Washington, D.C., May $1 \overline{9} 78$. 